\title{
MEMÓRIA E IDENTIDADE URBANA EM SANTOS: \\ usos e preservação de tipologias arquitetônicas da avenida Conselheiro Nébias
}

Dissertação de Mestrado

Orientadora:

MARIA IRENE DE QUEIROZ FERREIRA SZMRECSANYI

\author{
Universidade de São Paulo \\ Faculdade de Arquitetura e Urbanismo \\ Departamento de História e Fundamentos da Arquitetura e Urbanismo
}




\section{DEDICATÓRIA}

A meus pais:

que me proporcionaram memoráveis

(e inigualáveis) experiências urbanas. 


\section{AGRADECIMENTOS}

Esta dissertação, assim como minha trajetória acadêmica durante os três últimos anos, se deve, primeiramente, à minha orientadora profa. Dra. Maria Irene de Queiroz Ferreira Szmrecsanyi por sua disponibilidade e paciência em compartilhar um pouco do seu valioso conhecimento teórico em nossos encontros. Da mesma forma, sou grata as contribuições fundamentais feitas pela minha banca de qualificação profa. Dra. Maria Lúcia Caira Gitahy e prof. Dr. Carlos Roberto Monteiro de Andrade.

Agradeço também ao apoio técnico e financeiro da agência de apoio à pesquisa FAPESP, sem o qual está pesquisa não teria sido possível.

Enfim, agradeço aos meus pais pelo infindável apoio, carinho e paciência, sem os quais este percurso certamente teria sido mais penoso. Ao meu irmão Tarso e cunhada Ana Paula, pela confiança depositada em mim sempre e ao Rafael, pelo suave companheirismo nos momentos mais turbulentos. E finalmente à Flor e Jung, pela maneira inigualável de me ajudar a "clarear as idéias". 


\section{RESUMO}

O presente trabalho tem como objetivo a análise das condições contemporâneas de preservação de áreas com importância histórico-cultural, discutindo os sentidos do conceito de identidade e memória, dentro das tendências atuais de renovação urbana pela atuação do mercado ou do Estado. Um segmento da Avenida Conselheiro Nébias, em Santos, cujos quarteirões apresentam algumas edificações remanescentes da passagem do século XIX para o XX, período em que Santos se firmou como maior porto de exportação brasileiro, encontra-se em iminente ameaça e é objeto de estudo representativo desta problemática. Esse eixo, que conduziu o desenvolvimento da cidade, alcançou grande prestígio por se tornar local de moradia da elite comercial, política e dos profissionais ligados à economia do café que tentavam fugir do caos em que a cidade havia se transformado. Nas primeiras décadas do século $X X$, o trecho sofreu grande desvalorização após a migração dessas camadas abastadas para a orla, passando a ser ocupado por uma população de baixa renda da qual faziam parte portuários e operários, além de exescravos e imigrantes. As disposições do Plano Diretor de 1998 parecem conduzir para verticalização da área, o que pode resultar não só na expulsão da sua atual população, sob processo de gentrificação ou elitização, como também podem apagar vestígios capazes de reavivar a memória pública sobre uma região tão importante para a história santista, paulista e brasileira. Sendo assim, o trabalho defende sua preservação diante do valor cultural e histórico materializado nas suas construções, ao mesmo tempo em que alerta sobre as ameaças das atuais estratégias de gestão urbana.

Palavras-chave: Identidade urbana, Memória pública, planejamento estratégico 


\section{ABSTRACT}

The following research intends to analyze the contemporary conditions for preserving areas with historical and cultural significance, arguing the concepts of identity and memory, within the current trends of urban renewal by the performance of the market or the state. A segment of the Conselheiro Nébias Avenue, in Santos, whose building blocks have some remnants of the passage of the nineteenth century for the twentieth, period in which Santos was signed as bigger port of Brazilian exports, is in imminent threat and is an illustrative case study of this problem. This axle, which effectively led the development of the city, it reached great prestige for becoming place of residence of the comercial, political and professional elite linked to the coffee economy who tried to run away from the chaos that was taking over the city. In the first decades of the twentieth century, this part of the avenue suffered urban devaluation after that rich people migrated to the edge, being occupied by a low-income population, which were workers of the port, besides former slaves and immigrants. The provisions of the 1998 Managing Plan seem to lead the verticalization of the área, which can result not only in the expulsion of its current population, under a gentrification process, but also can erase traces able to revive the public memory on a so important region to History of Santos, Sao Paulo and Brazil. Thus, the work ahead defends its preservation before the cultural and historical value materialized in their buildings while at the same time warning us about the threats of current strategies of urban management.

KEYWORDS: Urban identity, public Memory, strategical planning. 


\section{LISTA DE FIGURAS}

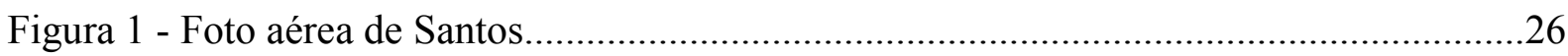

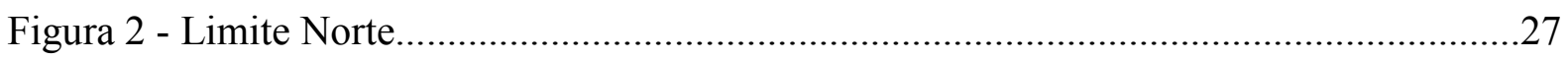

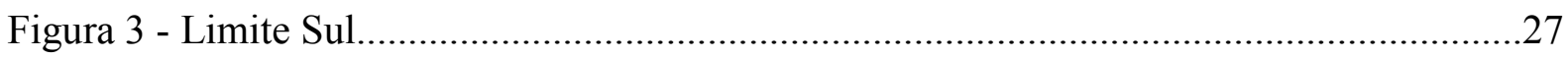

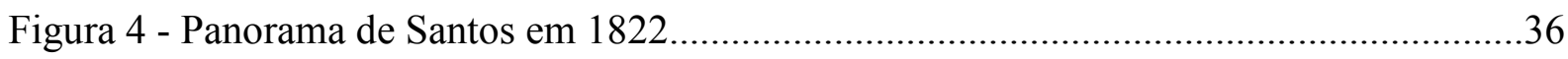

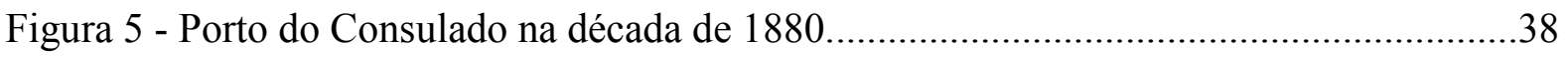

Figura 6 - A zona do Outeirinhos, entre Macuco e Vila Mathias............................................39

Figura 7 - Caminho Velho da Barra e Caminho Novo da Barra.............................................41

Figura 8 - Confluência entre Caminho Velho e Caminho Novo da Barra................................41

Figura 9 - Caminho Velho da Barra esquina com a antiga rua Áurea....................................42

Figura 10 - Avenida Conselheiro Nébias em 1904..............................................................43

Figura 11 - Avenida Conselheiro Nébias em 1910 ............................................................44

Figura 12 - Palacete J. Carneiro Bastos na Avenida Conselheiro Nébias................................45

Figura 13 - Estação de trem da São Paulo Railway Co. em 1865 ..........................................49

Figura 14 - Estação da São Paulo Railway Co. em 1905 .......................................................53

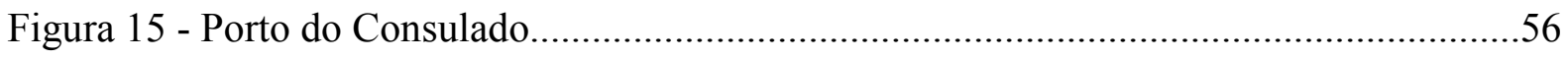

Figura 16 - Igreja e Convento do Valongo e o Porto das Canoas em 1840.............................58

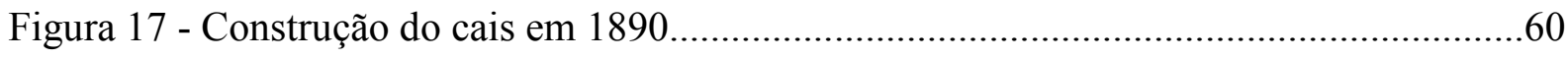

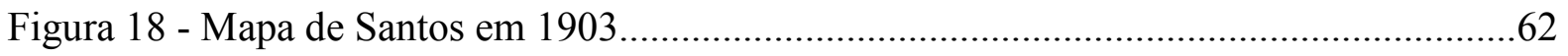

Figura 19 - Canal 1 no ano de sua inauguração................................................................67

Figura 20 - Vista de Santos a partir do Monte Serrat em 1915..............................................69

Figura 21 - Localização no traçado urbano da Avenida Conselheiro Nébias..........................135 


\title{
LISTA DE SIGLAS
}

\author{
APC - Área de Proteção Cultural \\ CDRU - Corredor de Desenvolvimento e Renovação Urbana
}

CONDEPASA - Conselho de defesa do patrimônio cultural de Santos

CONDEPHAAT - Conselho de defesa do patrimônio histórico, arqueológico, artístico e turístico.

COPLAN - Conselho Consultivo do Plano Diretor

CPC - Corredor de Proteção Cultural

IPHAN - Instituto do patrimônio histórico e artístico nacional

OTA - Órgão Técnico de Apoio

SEPLAN - Secretaria Municipal de Planejamento de Santos

ZEIS - Zona Especial de Interesse Social 


\section{SUMÁRIO}

Introdução. .10

Capítulo I - "Avenida Conselheiro Nébias: na segunda fundação de Santos e sob o planejamento estratégico"

I.1. Introdução

I.2. A Avenida Conselheiro Nébias atual: entre a revitalização e a preservação. 28

I.3. Panorama santista na virada do século 35

I.4. A expansão para a Barra e a Avenida Conselheiro Nébias 40

I.5. A crise da economia brasileira e a primeira fase do café.

I.6. Santos e a força de trabalho

I.7. A formação de uma nova sociedade

I.8. A modernização do porto de Santos.

I.9. As reformas urbanas em Santos

Capítulo II - "Memória e identidade urbana: discussão conceitual"

II.1. Introdução. 72

II.2. Memória e a formação da identidade nos indivíduos. 73

II.3. Memória e Espaço: tipologia e identidade urbana. 79

II.4. Memória e Poder. .86

II.5. Memória e esquecimento: o caso da Avenida Conselheiro Nébias 93 
Capítulo III - "Direito cultural na preservação urbana: alusão a teoria de Alöis Riegl".....

III.1. Introdução

III.2. Alöis Riegl e a questão do direito cultural. 98

III.3. Dominação cultural: o poder do patrimônio

III.4. A questão cultural nos processos de reapropriação territorial

Capítulo IV - "Desqualificação urbana e políticas neoliberais: o caso da Avenida Conselheiro Nébias"

IV.1. Introdução

IV.2. Aspectos morfológicos e socioeconômicos.

IV.3. Gestão urbana frente à política neoliberal.

Conclusão

V. 1. Considerações Finais 150

V.2. Proposta: diretrizes para uma nova legislação 153

Bibliografia. 163

Anexos 170

Anexo A - Grupos Tipológicos

Anexo B - Mapas.

Anexo C - Levantamento IBGE 


\section{INTRODUÇÃO}

"As cidades, como os sonhos, são construídas por desenhos e medos, ainda que o fio condutor de seu discurso seja secreto, que as suas regras sejam absurdas, as suas perspectivas enganosas, e que todas as coisas escondam uma outra coisa." 
Esta dissertação analisa um trecho da Avenida Conselheiro Nébias, em Santos, compreendido entre a rua Bittencourt e avenida Francisco Glicério e defende sua preservação diante do valor cultural e histórico materializado nas suas construções, ao mesmo tempo em que alerta para as ameaças que a área enfrenta ante as decisões do plano diretor atual da cidade.

Com a inauguração da ferrovia São Paulo Railway em 1867, Santos vivenciou um crescimento populacional vertiginoso, tornando imprescindível a expansão dos seus limites urbanos da época. A Avenida Conselheiro Nébias, aberta oficialmente no mesmo ano de inauguração da ferrovia, aparece como o veio estrutural que canalizou efetivamente esse desenvolvimento da cidade em direção a Barra, pois foi a primeira a unir diretamente o porto à orla, permitindo que a cidade se expandisse para a porção sul da ilha. A avenida se tornou um prestigioso eixo, onde primeiro foram postos em prática os ideais modernizadores correntes no período, como as medidas sanitaristas e de embelezamento.

Este segmento, composto por vinte e sete quarteirões, apresenta algumas edificações remanescentes da passagem do século XIX para o XX, período em que Santos se afirmou como maior porto de exportação brasileiro. A maioria dos edifícios construídos na avenida nessa fase se destinava a moradia da elite comercial, política e dos profissionais ligados à economia do café que tentavam fugir do caos em que a cidade havia se transformado. Após a migração dessas camadas abastadas para a orla, nas primeiras décadas do século $\mathrm{XX}$, o trecho sofreu grande desvalorização, sendo então ocupado por uma população de baixa renda da qual faziam parte portuários e operários, além de ex-escravos e imigrantes, que transformaram as antigas casas ou casarões burgueses em cortiços. 
A escolha dessa avenida como objeto de estudo se justifica não só pela relevância do eixo para a história urbana santista, mas principalmente por sua importância significativa para a memória histórica do país, uma vez que é um vestígio desse momento exportador decisivo para desenvolvimento econômico de São Paulo e, por conseguinte, insere-se na fundação do Brasil moderno e industrializado. Além disso, seus quarteirões são detentores de verdadeiros documentos sobre a moradia em Santos na primeira metade do século XX, sempre relacionadas a transformações econômicas do país.

A área mantém, em geral, o mesmo tipo de população de baixa renda que a ocupou há cerca de um século e que, ao longo desses anos, promoveu algumas adaptações e modificações no espaço de acordo com as suas necessidades, embora poucas tenham sido as demolições até o final do século XX. Dessa forma, a avenida foi transformada em área de habitação e comércio populares, em cujas construções está impressa a cultura dessas camadas da população.

Contudo, o planejamento atual prevê a verticalização da avenida sem cuidados para manutenção dos seus moradores no local. As disposições do Plano Diretor tendem a valorizar a área e, com isso, a atual população tende a ser expulsa, sob um processo de gentrificação ou elitização, tal qual ocorreu com a população pobre na mesma região durante as reformas urbanas praticadas em Santos há cerca de um século. Além disso, ao propor a renovação da área, a municipalidade incentiva demolições e se aproxima do ideal da tábula rasa, apagando vestígios capazes de reavivar a memória pública sobre uma região tão importante para a história santista, paulista e brasileira. Tratando-se de uma cidade 
com poucos pontos para expansão imobiliária, as medidas do Plano Diretor Municipal de 1998 parecem favorecer somente aos interesses do mercado.

Para analisar o problema e alternativas para a área, a dissertação está organizada em quatro capítulos e uma conclusão. O primeiro, intitulado "Avenida Conselheiro Nébias: na segunda fundação de Santos e sob o planejamento estratégico", apresenta o histórico material e cultural da avenida, distinguindo o trecho estudado - que é apenas uma parte dos seus 3.864 metros, no contexto de sua formação e consolidação na história urbana santista. Além disso, mostra a estreita vinculação entre o desenvolvimento urbano da cidade de Santos na segunda metade do século XIX e o apogeu da economia cafeeira que o impulsionou. Também concorre para a argumentação do capítulo uma apresentação acerca das expectativas municipais para a organização urbana da cidade, alertando para os processos destruidores da memória pública e da identidade urbana através da destruição da materialidade que compõe a avenida.

Nessa porção da avenida há alguns bens tombados e outros em estudo de tombamento, mas não há preocupação com seu entorno imediato. Dessa forma, outra questão pertinente à discussão do capítulo é o papel do patrimônio reconhecido nas atuais políticas públicas de gestão urbana, uma vez que esses bens provavelmente ficarão ilhados e abafados caso os incentivos da municipalidade para a verticalização da área se concretizem.

O segundo capítulo, "Memória e Identidade Urbana: discussão conceitual", partindo de uma abordagem que situa a memória como um dos elementos fundamentais da condição humana, cujo pré-requisito existencial, a despeito de sua característica fluida, é a materialidade, tem como preocupação 
central entender de que maneira tais suportes se tornam referências fundamentais para as práticas sociais e para a afirmação de identidades. Da mesma forma, analisa de que modo eles adquirem identidades no contexto urbano ao responderem aos anseios dos indivíduos no tempo histórico. Discute, por outro lado, a necessidade da preservação dessas estruturas materiais como chaves de acesso à memória, e analisa através da história os conflitos e os interesses envolvidos nesse processo.

Nota-se a importância da materialidade para a percepção do presente e para a permanência dos indivíduos na cidade, entendendo que os papéis assumidos pelos objetos nas relações sociais lhe são atribuídos pelo seres humanos e não uma propriedade intrínseca a eles. A partir dessa perspectiva, na qual o indivíduo é quem dá sentido as coisas e que são as práticas sociais que atribuem valor cultural a determinados objetos, argumenta-se no terceiro capítulo a favor do direito de manutenção de alguns bens culturais com os quais os sujeitos sociais desenvolvem ligações afetivas, sob garantia do Estado. Assim, uma possível dominação cultural exercida por alguns agentes no sentido de impedir ou desestimular a prática desse direito por todos os grupos que compõem a sociedade constitui questionamento desse capítulo.

Intitulado "Direito Cultural na preservação urbana: alusão à teoria de Alöis Riegl", o capítulo três toma ainda alguns aspectos teóricos da obra de Alöis Riegl para a compreensão da construção de identidades urbanas pelo Patrimônio Histórico, uma vez que o historiador de arte vienense foi um dos primeiros interlocutores dessa questão no discurso patrimonial. 
Diante desse panorama, os objetivos do quarto capítulo “Desqualificação Urbana e Políticas Neoliberais: o caso da Avenida Conselheiro Nébias" são os de compreender e discutir quais as metas e as conseqüências das orientações do Poder Público para a Avenida Conselheiro Nébias, cujo caráter simbólico e documental está descrito no primeiro tópico. Concorre para a discussão um panorama da atual estratégia do planejamento que visa à transformação do solo urbano em um produto lucrativo e à apropriação cenográfica da cidade, desconsiderando as referências de memória e identidade dos seus habitantes. A partir da ameaça de ocorrer o fenômeno de Gentrificação devido às regulamentações da municipalidade santista através do Plano Diretor, ao final do capítulo são propostas medidas de preservação da área sem tombamento, através de modificações na legislação urbanística, de modo a assegurar o direito cultural dos seus habitantes, visando à manutenção da memória pública e da identidade urbana da avenida.

Portanto, a dissertação assume como temáticas principais não só exposição da origem da degradação e do abandono da região central de Santos e da problemática da preservação de identidades urbanas na contemporaneidade, mas, sobretudo, traz um alerta para a urgência de uma visão social no planejamento e gestão das cidades, englobando as dimensões simbólicas com as quais os cidadãos se vinculam a materialidade, a fim de garantir a manutenção não só do direito à cidade, mas também dos valores de cidadania e da própria consciência democrática. 


\section{CAPÍTULO I}

Avenida Conselheiro Nébias: na segunda fundação de Santos e sob o planejamento estratégico

“que multidão de dependência na vida, leitor!

Umas cousas nascem de outras, enroscam-se, confundem-se, perdem-se e o tempo vai andando sem se perder a si mesmo..." 


\section{I.1. Introdução.}

Este capítulo busca as origens históricas da Avenida Conselheiro Nébias, mostrando sua estreita vinculação com a transformação urbana apresentada por Santos, na segunda metade do século XIX, a partir do desenvolvimento cafeeiro no oeste paulista, da qual a avenida participou como principal eixo estruturador da expansão para a porção sul da ilha em que se situa. Além disso, apresenta o sentido atual do planejamento urbano em Santos, alertando para os processos destruidores da memória pública e da identidade urbana dessa região tão significativa para a história da cidade.

Santos, por ser a principal porta de comunicação da província e depois do estado de São Paulo com o mar, torna-se, desde meados do século XIX, alvo de medidas que visavam ampliar o desenvolvimento da economia paulista, como a organização portuária e as reformas sanitaristas urbanas.

Aponta-se, assim, a fonte do dinamismo da transformação sofrida nessas décadas pela cidade de origem seiscentista, mudança cuja intensidade é aqui indicada pela expressão "segunda fundação", conforme o historiador Eurípedes Simões de Paula sintetizou o vigor das mudanças ocorridas na cidade de São Paulo, das quais Santos foi um complemento indispensável.

A "segunda fundação de Santos" ocorre a partir de 1867, com a chegada da linha férrea da São Paulo Railway e, posteriormente, com a reestruturação do porto, quando a cidade deixa suas características coloniais e parte rumo a uma estrutura e imagem físico-social modernas. Justifica-se na medida em que as mudanças ocorridas nesse período foram possíveis devido à entrada de 
capital internacional através das operações de financiamento da economia cafeeira, tal qual ocorreu no episódio paulistano.

A Avenida Conselheiro Nébias configurou-se em um prestigioso e importante eixo norteador do crescimento da antiga cidade, nascida junto ao cais, para as praias, permitindo a construção da Santos balneária. Todavia, após a ocupação efetiva da orla, a avenida teve sua porção mais próxima ao porto desvalorizada. Hoje, essa região se tornou alvo de investimentos incentivados pelo Poder Público, ameaçando de expulsão das 27 quadras imediatamente além trilhos (partindo-se da praia) aqui estudadas os segmentos sociais de baixa renda que substituíram os primitivos moradores, ocupando e adaptando as edificações do local por mais de um século.

A necessidade de um porto bem estruturado foi fundamental para o avanço das atividades de importação-exportação. Como mostram diversos autores ${ }^{1}$, o volume de mercadorias que passava pelo porto havia sido largamente ampliado a partir da inauguração da linha férrea São Paulo Railway. Em razão do mais rápido e seguro transporte das sacas cafeeiras no difícil trecho da serra do mar, a linha férrea permitiu que a demanda do mercado externo estimulasse a penetração dos sertões por outras ferrovias para plantio e escoamento do café, de forma que este chegasse em boas condições ao embarque marítimo. Do mesmo modo, a facilidade de comunicação com o planalto associada à necessidade de mão de obra nas fazendas do interior permitiu que Santos se tornasse o porto de desembarque de numerosos contingentes de imigrantes estrangeiros. Assim, em 1888, abre-se concorrência para ampliação e modernização do porto, vencida por um grupo de empresários liderados

\footnotetext{
${ }^{1}$ Gitahy (1992); Szmrecsanyi (1984); Silva (1985); entre outros.
} 
por Eduardo Palassim Guinle e Cândido Gaffrée, que inauguram os primeiros 260 metros do cais em 1892.

Em decorrência desses processos, no final do século XIX, Santos sofreu um crescimento populacional espantoso composto por contingentes de trabalhadores do porto (muitos dos quais imigrantes), comerciantes de vários portes, incluindo uma elite de comissários e corretores, além de banqueiros e finaciadoresimportadores transacionando com o café, seu financiamento, a oferta de produtos estrangeiros. A esses grupos, somavam-se ainda levas de ex-escravos, alguns dos quais provenientes de antigos quilombos.

Nesse panorama, a ameaça e a ocorrência de epidemias, principalmente a de febre amarela, traziam instabilidade para a economia que prosperava no interior do estado e ocasionaram uma série de intervenções nas estruturas urbana e social da cidade. O saneamento de Santos e as reformas urbanísticas acopladas foram impulsionados por interesses explícitos de uma elite econômica bem representada nas várias instâncias governamentais e que se associou a interesses de capitais estrangeiros.

Essa burguesia participava ativamente da estrutura política municipal, estadual e federal, utilizando-se desse controle não só para desenvolver a economia cafeeira, mas também os negócios com serviços urbanos, considerando o seu próprio bem estar. Foi essa burguesia que definiu os modelos funcional, social e estético que a cidade deveria ter por meio de novos recursos sanitários, de novos traçados urbanos, das novas construções e de novos modos de vida.

Os modelos urbanísticos pelos quais essas reformas se pautaram foram escolhidos não só por razões técnicas ou de embelezamento e representação, 
mas também comandados por interesses imobiliários permitidos, sobretudo, pelo saneamento das terras próximas à praia.

As reformas urbanas sanearam tanto a estrutura física de Santos quanto pretenderam "ordenar" as camadas sociais mais pobres. Aqueles que não se adaptassem aos novos modos exigidos seriam expelidos para a periferia e encostas dos morros.

A Avenida Conselheiro Nébias, cuja abertura oficial se deu em 1867, funcionou como a espinha dorsal dessa expansão e se tornou o símbolo dos novos padrões burgueses, principalmente na porção mais central próxima ao porto - a primeira a ser ocupada pela elite em fuga da superpopulação que havia se apropriado das proximidades da estação ferroviária, no Valongo.

Após as drenagens promovidas pelo Estado, projetadas inicialmente pelo Engenheiro Estevan Fuertes na década de 1890 e levadas adiante por Saturnino de Brito de 1905 a 1910, a avenida foi também responsável pelo povoamento da zona intermediária entre o cais e a Barra (BERNARDINI, 2006; LANNA, 1996).

Inicialmente chamada de Rua da Independência, passando a Rua Octaviana e posteriormente rua e Avenida Conselheiro Nébias, sua ocupação, assim como a abertura de outras avenidas largas em Santos, está ligada à idéia de 
modernidade buscada pelas famílias que vêem aumentar seu poder aquisitivo como conseqüência do surto cafeeiro do estado de São Paulo².

Após a ocupação efetiva da orla, o que definiu desde os áureos tempos do café o segmento final da avenida como sua área mais valorizada, a porção central foi ocupada pela mesma população pobre que inicialmente fora excluída das melhorias trazidas pelas reformas: portuários e operários, ex-escravos e imigrantes, encortiçados nas antigas casas ou casarões burgueses. O espaço foi sendo por eles adaptado às suas necessidades e algumas edificações foram demolidas, outras construídas, porém dentro do perfil socioeconômico e morfológico da área. Assim, ao longo dos anos a identidade dessa população foi impressa nas edificações e as práticas sociais vinculadas a essa área passaram a espelhar a cultura desses moradores e seus descendentes.

Outra peculiaridade da Conselheiro Nébias encontra-se no fato de que, ao percorrer o bairro do Paquetá, ou seja, nos quarteirões mais próximos ao porto, ela é mais estreita, caracterizando-se mais como rua e assim sendo designada. Essa diferença nos serve para delimitar o início do território em estudo nesta pesquisa, seu limite norte. Dali para frente a Conselheiro Nébias se alarga, tornando-se avenida, e será analisada até seu cruzamento com a linha do trem a 27 quadras dali - o limite sul.

O cruzamento da avenida com a estrada de ferro foi utilizado como critério para demarcar o limite sul porque o trecho que dali avança para a praia

\footnotetext{
${ }^{2}$ Nome dado em homenagem ao santista Dr. Joaquim Octávio Nébias que, segundo RODRIGUES (1971), foi um político importante no cenário santista tornando-se figura de grande influência no Brasil Império. Em 1852, foi nomeado Presidente da Província do Rio Grande do Sul e, no mesmo ano, Presidente da Província de São Paulo. Ocupou ainda os cargos de Senador, presidente da Assembléia da Câmara dos Deputados no Rio de Janeiro, Ministro da Justiça, Juiz dos Feitos da Fazenda e Conselheiro Imperial de D. Pedro II.
} 
sofreu e vem sofrendo revalorização urbana acelerada, processo que ocorre no sentido contrário, ou seja, da praia em direção ao cais (sul-norte), estancando nos trilhos. Sendo assim, a linha vem permitindo à classe de baixa renda que ocupou a área continuar a habitá-la. Também por isso, nesse trecho foram feitas menos demolições e as edificações apresentam apenas reformas com preocupações utilitárias, mantendo seus traços históricos.

Optou-se por estudar nesta dissertação o trecho da avenida onde originalmente ocorreu o fenômeno da reocupação por uma classe diferente daquela inicial. É importante ressaltar que foi descartado o trecho inserido no bairro Paquetá porque nele a Conselheiro Nébias não só continuou como uma rua estreita, mas também não sofreu o processo de modernização comandado por leis de embelezamento, como ocorreu na sua continuidade dali até os trilhos. Além disso, quando o cais do porto chegou ao Paquetá, a região foi rapidamente abandonada pelas elites que se deslocaram um pouco mais para o sul no próprio eixo da Conselheiro, passando a ocupar a Vila Nova, bairro onde se inicia seu alargamento, ou seja, a avenida propriamente dita.

A partir do plano diretor de 1998, a proposta municipal para a área é a de que ela receba investimentos da iniciativa privada e seja verticalizada, ou melhor, que ela seja "revitalizada". Em nenhum momento, a proposta municipal menciona meios para manutenção de sua atual população na avenida que se pretende reconstruir. Pode-se, então, entender o termo revitalização em duplo sentido, já que se pretende valorizar espacial e economicamente os terrenos da área, o que pode resultar também em sua transferência para outros segmentos sociais. 
Desse modo, configura-se a ameaça de ali ocorrer o processo conhecido por gentrification, com a reapropriação da região por camadas sociais mais aquinhoadas economicamente do que as que hoje a habitam. Se isto se der, o 'progresso' da cidade implicará na demolição de remanescentes de um passado notável e no afastamento da população pobre do local. Esta dissertação alerta para que esses encaminhamentos que considera errôneos sejam repensados, replanejados e não venham a acontecer.

Assim, o objetivo do capítulo é duplo: não só mostrar como na segunda metade do século XIX a dinâmica do capital promoveu a expansão urbana santista e o povoamento dos primeiros quarteirões da avenida, mas como logo depois, em tempos hoje também distantes, ocorreram reformas urbanas promotoras de exclusão que expeliram para fora do perímetro urbano alguns segmentos sociais que ali viviam, redesenhando seu habitat em beneficio de outros mais ricos, tal qual parece se delinear hoje ou mesmo começa a acontecer.

Não sem razões, porém, já no início do século $X X$, de novo uma população pobre veio a ocupar esse lugar quando do abandono das casas burguesas em favor da orla, permanecendo nesse segmento da avenida a classe social de trabalhadores braçais ou de baixa renda até a atualidade.

Portanto, a dissertação assume dois momentos fundamentais para o estudo do trecho escolhido da Avenida Conselheiro Nébias e das transformações urbanas em Santos: o primeiro compreende o final do século XIX e início do XX, mais precisamente de 1867 a meados dos anos 10 do século seguinte. Esse primeiro momento compreende o período da chegada da linha férrea a Santos e da abertura oficial da avenida, até o abandono do trecho estudado pelas elites ligadas à 
economia do café e sua ocupação por outros grupos sociais. O segundo período estudado se inicia nos anos 90 do século $X X$ e se estende até a atualidade, período da aprovação do Plano Diretor do município de Santos e das propostas de "revitalização" acima apontadas.

Este salto de quase um século no estudo da historiografia da área se justifica na medida em que são esses os dois momentos que repercutiram de maneira marcante no trecho estudado, tanto nos seus aspectos morfológicos quanto no perfil socioeconômico dos seus moradores.

O período intermediário entre os dois momentos escolhidos é marcado por intensas transformações na cidade de Santos, principalmente na região da orla, onde a procura e o valor dos imóveis crescem seguidamente. Porém, justamente esse deslocamento do eixo de valorização do solo urbano para a orla e o desprezo imobiliário pelas redondezas do porto como local de moradia é que garante a manutenção das construções no trecho estudado da Avenida Conselheiro Nébias. Assim, esse segmento permanece praticamente intacto quando comparado àquele posterior a linha férrea, em direção à praia. Ao contrário do que aconteceu no restante da cidade onde a memória foi sendo apagada em função da construção de uma imagem modernizadora, como aconteceu com vários edifícios da orla demolidos para ceder lugar a novas construções ${ }^{3}$, o trecho estudado manteve suas características iniciais, as quais foram sendo incorporadas à memória e à identidade dos seus moradores através do uso contínuo dentro de seus próprios hábitos e necessidades, levando a pequenas adaptações que, na maioria das vezes, não

\footnotetext{
${ }^{3}$ Vide o caso do Hotel Parque Balneário, derrubado em 1925 para a construção do novo Hotel Parque Balneário.
} 
chegaram a desvirtuar a volumetria original das construções, nem mesmo sua fachada ou ornamentação exterior.

Entretanto, a partir da aprovação em 1998 do Plano Diretor do município de Santos, as memórias públicas e privadas sedimentadas nessa porção histórica da avenida passam a correr o risco de serem apagadas, pois o sentido da sua programação atual é ter sua identidade substituída, forjando-se uma nova área comercial e de classe média a partir do incentivo a investimentos imobiliários.

A dinâmica do descarte e do consumo não está limitada à capacidade de se desfazer de bens produzidos, mas, sobretudo, "significa também ser capaz de atirar fora valores, estilos de vida, relacionamentos estáveis, apego a coisas, edifícios, lugares, pessoas e modos adquiridos de agir e ser" (HARVEY, p. 258, 2003). A capacidade de lembrar e a manutenção da memória se esvaecem em função do consumo de imagens fabricadas para suprir desejos. Na pósmodernidade, a criação do desejo é vital para a manutenção do mercado, assim como sua satisfação parcial pelo consumo. Com a venda de todo tipo de imagem, o mercado parece realizar qualquer vontade, o que na realidade acontece parcialmente, uma vez que essas imagens são desprovidas de conteúdo e de memória, são simulacros.

O simulacro realimenta o mercado, pois para cada frustração são oferecidas novas imagens, aprisionando o consumidor num ciclo de possibilidades fadadas ao fracasso. Neste sentido, o consumo se opõe à liberdade, apesar de prometê-la (BAUDRILLARD, 1975).

Neste turbilhão de simulacros, a cultura se torna mercadoria e a cidade, como seu suporte direto, é gerida e consumida como tal. Por isso, a cidade 
passa a ser "feita" por grandes empresas (capital privado) com total aval do Estado, através de um novo modelo de planejamento urbano que incorpora estratégias empresariais para tornar as cidades competitivas o suficiente a ponto de atraírem investimentos e gerarem lucros. Essas estratégias se baseiam na venda de imagens "positivas" da cidade, muitas vezes inventadas ou exageradas ${ }^{4}$ desde que se tornem lucrativas.

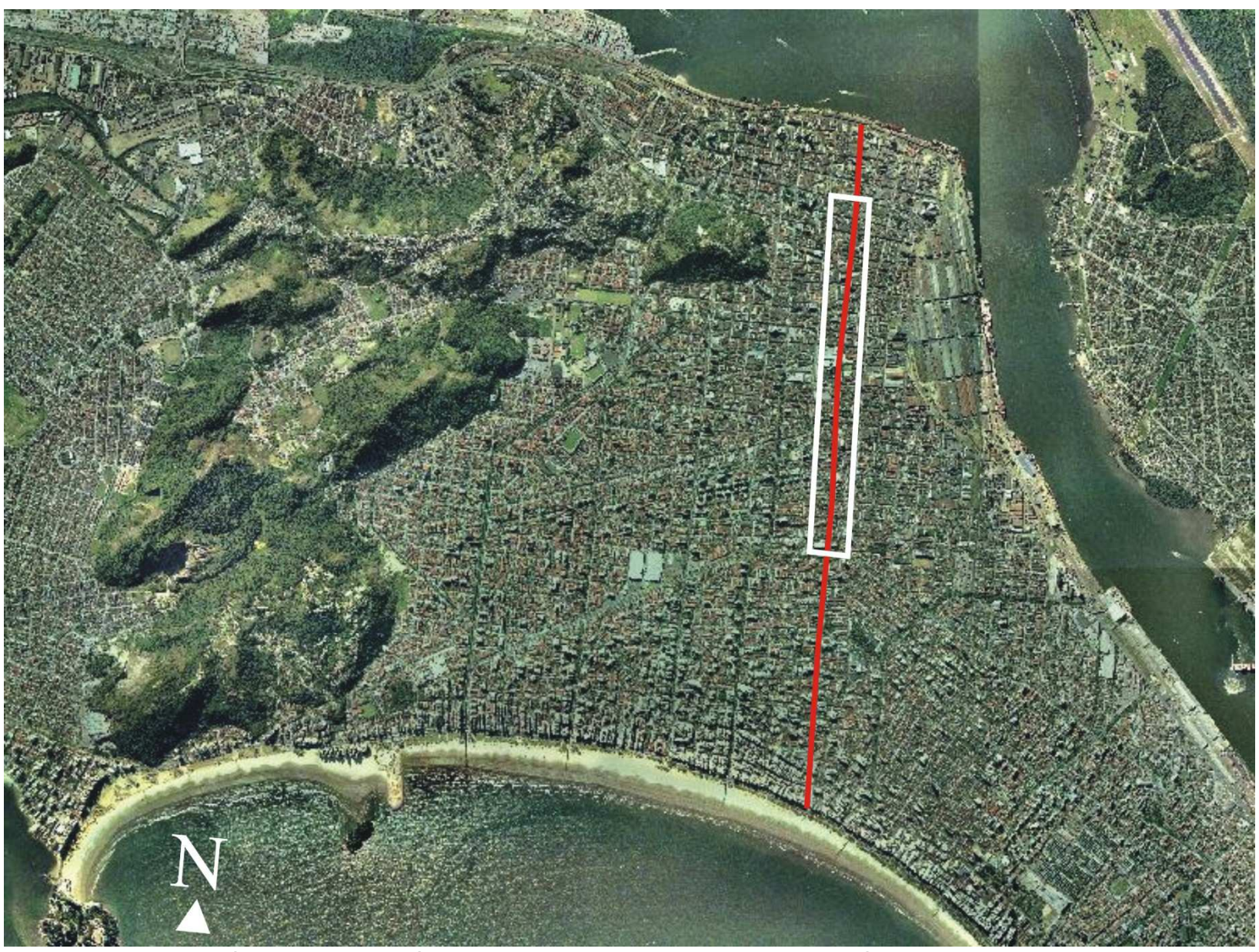

Figura 1: Na foto aérea de Santos está destacada a Avenida Conselheiro Nébias em vermelho e o trecho estudado em branco.

(Fonte: foto aérea disponível no site Santos Digital)

\footnotetext{
${ }^{4}$ Como exemplo disso, temos os slogans de algumas cidades que são, muitas vezes, invenções ou exacerbações de características com a finalidade de atrair investimentos ou turismo.
} 


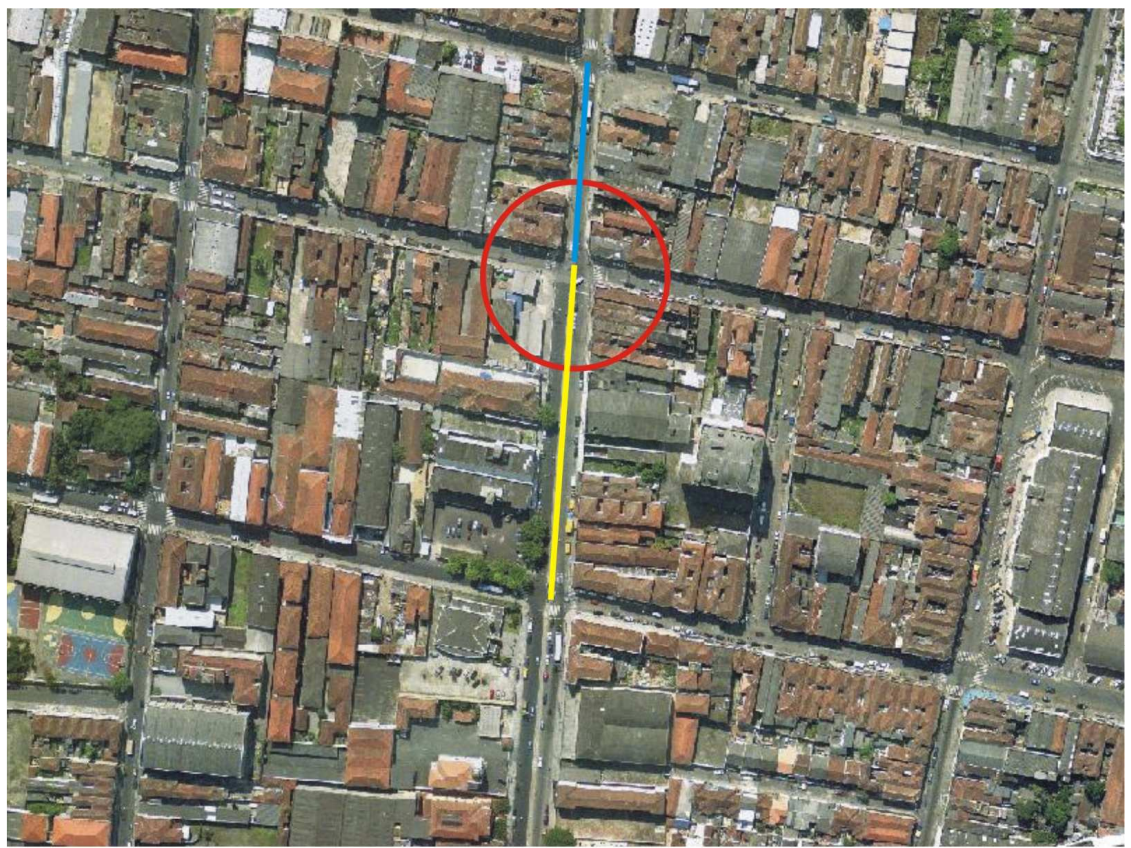

Avenida Conselheiro Nébias

— Rua Conselheiro Nébias

Figura 2: Limite Norte - ponto que mostra a junção da parte mais antiga e estreita da Conselheiro Nébias, aí designada rua (em azul), com o primeiro quarteirão do trecho mais amplo, designado avenida (em amarelo). (Fonte: site Santos Digital)

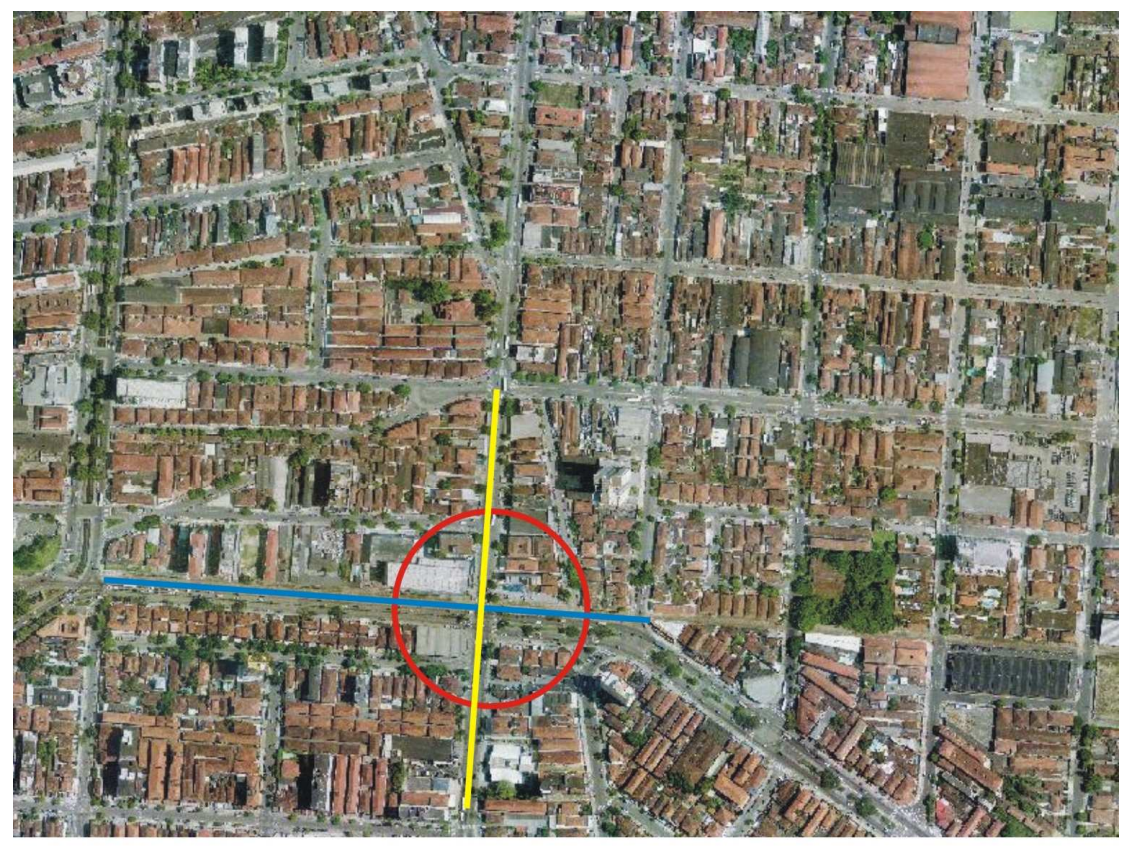

Avenida Conselheiro Nébias

Linha do trem

Figura 3: Limite Sul - ponto onde a linha férrea cruza a avenida. (Fonte: foto aérea disponível no site Santos Digital) 


\section{I.2. A Avenida Conselheiro Nébias atual: entre a revitalização e a preservação.}

Os processos de gentrificação (gentrification) que se tornaram tendência analisada em famosas cidades dos Estados Unidos e da Inglaterra a partir dos anos 80 de fato não são novos e muito menos inéditos no Brasil. É bem estudada a reurbanização no início do século XX da área próxima ao porto do Rio de Janeiro, consagrada pela construção da Avenida Central, que resultou em sua elitização pela expulsão da população encortiçada desse local e nas primeiras favelas dessa cidade ${ }^{5}$.

Santos foi palco de processos semelhantes no passado durante as reformas higienistas e parece estar novamente disposta a repeti-los, em sua versão atual. As reformas que procuravam sanear não só a estrutura física da cidade, mas principalmente limpá-la das mazelas sociais, também culminaram com a expulsão da população pobre e encortiçada para fora dos perímetros do que era considerada cidade na época 6 .

No Brasil contemporâneo, principalmente em cidades com os núcleos iniciais reconhecidos pelo Patrimônio Histórico, vem-se tentando atrair camadas de maior poder aquisitivo para as áreas centrais. Os órgãos de planejamento urbano e os governos patrocinam sua transformação em lugares de consumo turístico - como é o caso do Pelourinho em Salvador, ou a área do porto em Recife - como forma de preservação desses locais. Em outros casos, procura-se "reabilitar" áreas centrais degradadas fisicamente e habitadas por trabalhadores

\footnotetext{
${ }^{5}$ Sobre as principais propostas urbanas do século XX para o Rio de Janeiro ver, por exemplo, Moreira (2004).

${ }^{6}$ Sobre as reformas urbanas em Santos ver: Andrade (1992), Andrade (1989) e Bernardini (2006).
} 
pouco qualificados ou por população excluída dos mercados de trabalho e de consumo, reequipando-as para se tornarem áreas de uso, seja para trabalho, lazer ou mesmo moradia de camadas sociais mais abastadas, como acontece em Santos (na APC - Área de Proteção Cultural), por exemplo. A conseqüente valorização dessas áreas acaba por expulsar seus antigos moradores.

Deste modo, entendemos que tais propostas de "revitalização", ao excluírem a população que realmente dá significado a área com suas práticas sociais, promovem imagens com significado postiço, ou seja, transformam essas áreas (muitas vezes patrimoniais) em simulacros urbanos.

"O fechamento das fronteiras urbanas a 'visitantes e usuários insolventes' certamente se funda no mesmo tipo de visão da cidade e do mundo: o direito à cidade, neste caso, passa a ser diretamente proporcional ao índice de solvência dos estrangeiros e visitantes. Aquilo que, de certa maneira, já é uma realidade, transforma-se agora em projeto, em estratégia de promoção da cidade." (VAINER, p. 80, 2000)

Esse tipo de planejamento analisa, estrategicamente, de que maneira as diversas regiões da cidade possam se tornar mais lucrativas: onde o solo tem valor agregado pelo patrimônio (que pode vir a ser explorado pelo turismo), onde sua rentabilidade será maior pela verticalização, etc., como ocorre em Santos cujo Plano Diretor propõe a preservação do núcleo urbano inicial (APC) e a verticalização da Avenida Conselheiro Nébias, sem medidas de preservação dos moradores na área e, portanto, em detrimento das relações sociais, assim como, através delas, dos sentidos de identidade e memória que hoje dão vida a esses espaços. Ora, se a hegemonia ideológica e política na sociedade depende diretamente do controle das representações materiais dos indivíduos, como demonstrou Harvey (2003), o domínio do espaço é um dos pontos fundamentais para a manutenção do poder político. Portanto, conclui-se que, no caso da atual 
política urbana, a preservação de memórias e identidades urbanas está sendo menosprezada pelo Estado, deixando a interesses privados representados pelo capital imobiliário as decisões sobre onde e o que preservar ou demolir, o que tende a ocorrer exclusivamente a partir de análises sobre a rentabilidade do solo. Nesse processo, no qual o poder político migra para as mãos de grandes investidores, o Estado assume papel fictício e a cidadania é abolida.

Em Santos, o Plano Diretor de 1998, claramente influenciado pelas mudanças ocorridas mundialmente na economia e no planejamento urbano, insere a Avenida Conselheiro Nébias no chamado Corredor de Desenvolvimento e Renovação Urbana - CDRU com a pretensão de adensar a região através da verticalização. Para isso, utiliza-se de instrumentos específicos, definidos no Título IV - Dos instrumentos urbanísticos de incentivo, Capítulo I - Das Disposições Gerais, dessa mesma Lei:

"Art. 72 - São considerados instrumentos da política urbana e mecanismos de planejamento urbano:

I - o parcelamento, edificação ou utilização compulsório;

II - usucapião especial de imóvel urbano;

III - direito de superfície;

IV - direito de preempção;

$V$ - outorga onerosa do direito de construir;

VI - outorga onerosa do direito de alteração de uso do solo;

VII - transferência do direito de construir;

VII - operações urbanas consorciadas;

IX - regularização fundiária;

$X$ - estudo prévio de impacto de vizinhança (EIV)"

Segundo o $\S 1^{\circ}$ desse artigo, a Outorga Onerosa do Direito de Construir, instrumento previsto no Estatuto das Cidades no Capítulo II - dos 
instrumentos da política urbana, Seção I - dos instrumentos em geral, artigo $4^{\circ}$, que prevê ao beneficiário a compra de adicional do coeficiente de aproveitamento, no caso de Santos só permitido "em caso de imóveis situados em Corredores de Desenvolvimento e Renovação Urbana - CDRU, e em Operações Urbanas Consorciadas". Isso significa que, nessas regiões, o adicional de coeficiente de aproveitamento concedido por lote e adicionado à área construída nele permitida poderá chegar a 7,0 (sete) vezes a área do lote nas Zonas Intermediária - ZI e Central II - ZCII (zonas onde está inserido o trecho estudado nesta pesquisa).

Outro instrumento que incentiva a verticalização do trecho é a transferência do direito de construir, também previsto no Estatuto das Cidades e estabelecida pelo Capítulo IV - da transferência do direito de construir dessa mesma Lei urbanística municipal. Este instrumento é um incentivo à preservação dos imóveis tombados e com níveis de proteção situados no Corredor de Proteção Cultural - CPC (estabelecido por essa Lei) e consiste na compensação pela não utilização do coeficiente de aproveitamento permitido na respectiva zona de uso. Os artigos 85 e 86 desse capítulo, estabelecem que a transferência do direito de construir pode ser realizada apenas para imóveis localizados no Corredor de Desenvolvimento e Renovação Urbana e/ou em áreas de Operações Urbanas Consorciadas. Também informa que todos os imóveis localizados no CDRU podem receber tal transferência vinda de imóveis gravados com níveis de proteção. Dessa forma, entende-se que a história e a memória da população moradora da avenida serão extintas para preservar outra parte da cidade, ou seja, há uma eleição de quais memórias, das memórias de quem, se pretende preservar em Santos.

Existe na cidade um órgão municipal autônomo e deliberativo que cuida do tombamento e da preservação dos bens culturais e naturais do município, o 
CONDEPASA. Tal órgão conta com um corpo de conselheiros e um órgão técnico de apoio (OTA) para deliberar sobre as medidas a serem tomadas para a proteção do patrimônio cultural santista. Alguns bens são tombados pelo CONDEPASA ao longo de toda a Avenida Conselheiro Nébias, outros estão em estudo de tombamento. Entretanto, como a preocupação do poder público para a área é a de transformá-la em área lucrativa, verticalizada, os bens tombados ou em estudo de tombamento, devido ao CDRU, não possuem área envoltória, com raras exceções. Um exemplo é que, em todo o trecho estudado (somam-se 27 quadras), apenas para um dos bens tombados existe regulamentação de área envoltória. Assim, entende-se que os demais bens ali tombados, como por exemplo, o edifício da Capitania dos Portos, ficarão ilhados num futuro próximo quando o incentivo do Poder Público à verticalização e adensamento se concretizarem, já que esses imóveis, assim como a maioria das quadras do trecho, seguem o perfil de no máximo 2 ou 3 pavimentos.

Com relação ao zoneamento, uma pequena parte do trecho estudado está inserida na ZEIS 3, região mais próxima ao bairro do Paquetá. Segundo a Lei Complementar 53 de 1992, as ZEIS são Zonas de Interesse Social que têm por objetivo adequar a propriedade do solo à sua função social, criando condições especiais para maior aproveitamento do terreno através de índices urbanísticos e parâmetros construtivos privilegiados para habitação popular. A criação dessa zona está prevista no Estatuto da Cidade (Lei Federal 10527/2001) com a intenção de possibilitar edificações com área construída maior do que em um terreno que não seja de interesse social. Integrando a lei municipal, foi sancionada no dia 29 de maio de 2002 a Lei Complementar n 457/2002, alterando o anexo I da LC $n^{\circ}$ 53, de 15 de maio de 1992, que criou as Zonas Especiais de Interesse Social 
(Zeis). Segundo o Diário Oficial de Santos do dia 29 de maio de 2002 "ficaram estabelecidas condições para a construção de moradias com verbas dos programas habitacionais, promovidos pelo Governo Estadual", sendo o Município responsável em promover o ordenamento territorial, mediante planejamento e controle de uso.

Todavia, na mesma área destinada à habitação popular foi construída a sede administrativa da primeira Unidade de Negócio de Exploração e Produção da Petrobrás no Estado de São Paulo, a Unidade de Negócio da Bacia de Santos (UN-BS). A unidade ocupa quatro pavimentos do Centro Empresarial Strong, que pertence à empresa Strong Consultoria Empresarial e Factoring, associada à Fundação Getulio Vargas - FGV.

Nesse local, funcionam estações de interpretação de dados sísmicos, além de salas de videoconferência e equipamentos de informática e telecomunicações que certamente não estão à disposição da comunidade local, já que a unidade tem por objetivo, dentre outros, promover cursos de formação para os funcionários recém admitidos nos seus concursos que, por sua vez, também não atingem a população da região por exigirem especialidade na área de atuação. Além disso, certamente os cursos de MBA e pós-graduação oferecidos pelas instituições FGV ou Strong não têm como público alvo os encortiçados do Paquetá ou Vila Nova.

Apesar das inúmeras vantagens que a implantação da Bacia de Santos trará para cidade, não acredito que atingirá de maneira imediata a população moradora e muito menos que a instalação desse tipo de instituição no local promova algum tipo de melhoria na sua condição de vida. Da mesma forma, é difícil imaginar outros motivos para esse tipo de construção no local (e vale ressaltar: monumental, com seus vidros azuis espelhados destoantes na paisagem de sobrados geminados, 
construídos no final do século XIX), além das vantagens oferecidas pelo município quanto à possibilidade de verticalização, teoricamente destinada à construção de habitação popular.

Carvalho (2007), ao analisar o período político que antecedeu a aprovação do plano diretor de Santos demonstra o fracasso das tentativas da exprefeita Telma de Souza, do PT, em alterar o perfil do Conselho Consultivo do Plano Diretor - COPLAN. À população, coube a participação de aceitar as definições impostas.

"Assim, nos oito anos de governo da Unidade Democrática Popular (formado pelo PT, PSB, PC do B e PV, acrescida pelo PMN), os interlocutores privilegiados da política de planejamento urbano em Santos foram os grupos sociais representados no Coplan, predominantemente os setores ligados à produção imobiliária, que, no caso especifico de Santos, eram liderados pela Associação dos Empresários da Construção Civil da Baixada Santista, a Assecob." (CARVALHO, 2007)

Dessa forma, entendo que o "progresso" de Santos, defendido ideologicamente pelo capital privado e corroborado pelo Poder Público, ocorrerá à custa do afastamento da população pobre da avenida mais uma vez, já que, em nenhum momento, a proposta municipal menciona a inclusão dessa população na área que se pretende renovar, assim como não há preocupação com seu destino.

Este mesmo fato pôde ser observado no episódio da expansão para a praia da Barra, quase um século atrás na mesma porção da Avenida, quando esse mesmo segmento social foi excluído das melhorias promovidas pelas reformas urbanas. A Avenida Conselheiro Nébias participou ativamente não só do processo de desenvolvimento e expansão da cidade em direção a porção sul da ilha como também da primeira fase de expansão da cidade para fora dos limites do centro, com a construção dos bairros Paquetá e Vila Nova nas cercanias da avenida, 
merecendo atenção especial da municipalidade nos dois momentos. Entretanto, verifica-se que na medida em que sua porção próxima ao porto deixou de ser ocupada pela elite, a área foi abandonada também pelo Poder Público.

\section{I.3. Panorama santista na virada do século.}

A partir da segunda metade do século XIX, transformações significativas tanto na porção físico-territorial, como na estrutura social, passaram a acontecer na cidade de Santos. Essas mudanças vividas não só por Santos, como por outras tantas cidades, revelavam a formação de uma nova sociedade urbana, o que implicava em novos métodos de intervir na cidade.

Na Europa depois de 1850, a urbanização cresceu rapidamente em decorrência da industrialização, o que levou a um aumento do número de habitantes nas cidades em função destas se tornarem o centro da produção econômica. Floresce o mundo burguês contrapondo-se a concentração de pobres na cidade, acarretando medidas sanitárias e de embelezamento no planejamento urbano (BENEVOLO, 1999; HOBSBAWM, 1996).

Em Santos, a expansão da cidade e a ocupação efetiva de todo o território santista se deu um pouco mais tarde, trazida pelo crescimento populacional vertiginoso na virada do século e permitida por reformas sanitaristas, cuja necessidade se fazia sentir para continuidade das exportações. A população da cidade, que não passava de 13.012 habitantes em 1890, salta para 50.389 pessoas na virada do século, um crescimento de $287 \%$ (GONÇALVES, 1995). Até então a população se concentrava no que hoje denominamos centro, uma faixa de terra espremida entre a praia do porto e os morros de São Bento e de São Jeronymo 
depois chamado de Monte Serrat. Como descreve Guilherme Álvaro, a cidade estava restrita por barreiras naturais:

"Até 1850, Santos continuava a se desenvolver sensivelmente para os lados dos 'quartéis'. As edificações na praia estenderam-se bem para além da rua da Palha, abrindo-se para a rua Nova, depois General Câmara, transpondo o largo da Coroação, hoje Praça Mauá, o melhor daquelle tempo, em que era o 'rocio' da cidade. A rua das Flores, depois Amador Bueno, que saía de São Jeronymo, fronteiro à Santa Casa, atingia o largo chamado depois Mauá e em seguida José Bonifácio, e começava a transpô-lo em direção ao Paquetá, onde mais tarde foi feito o Cemitério. As ruas saídas da praça da Matriz buscavam as fontes do Itororó e Das Duas Pedras, aonde a cidade acabava." (ÁLVARO, apud BLUME, 1998, p. 41)

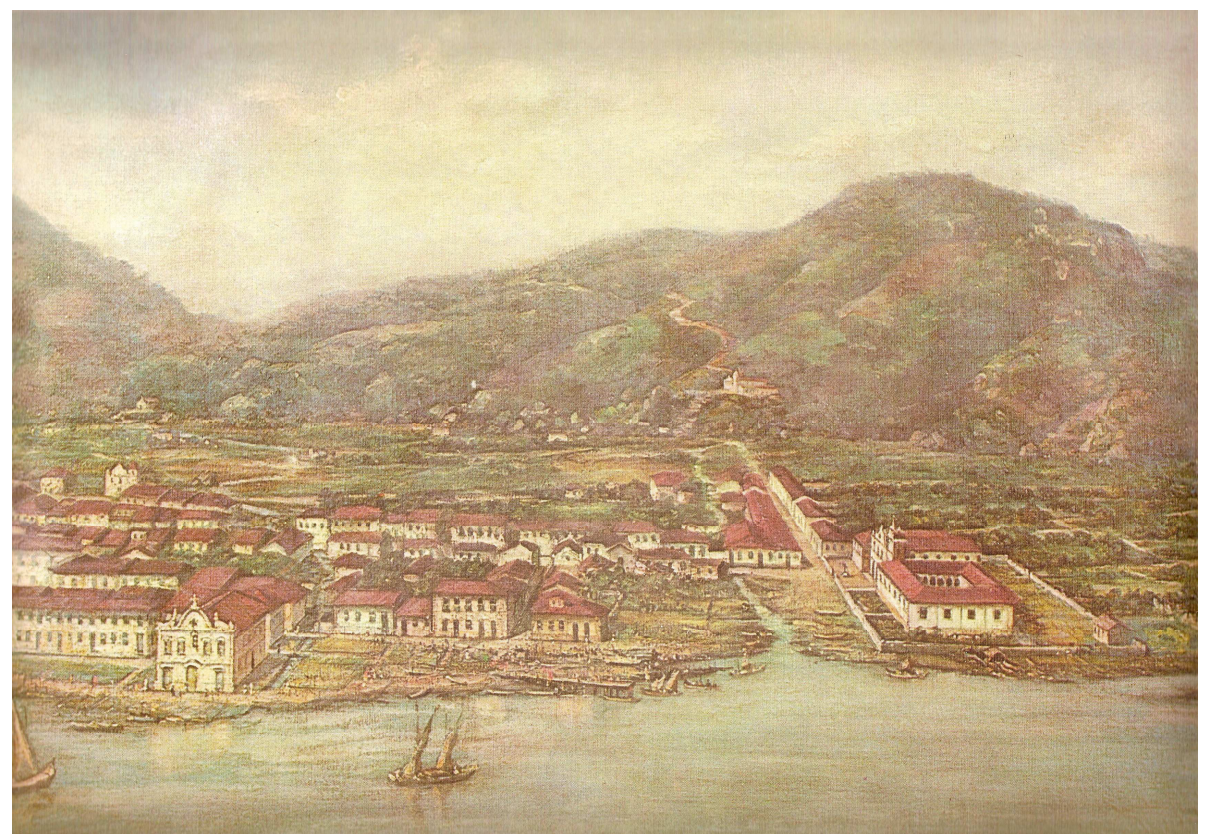

Figura 4: Panorama de Santos em 1822 - tela de Benedito Calixto. Vê-se Santos ainda como um pequeno povoado espremido pelos morros.

(Fonte: PRODESAN)

Com o adensamento populacional, inúmeras doenças se alastravam como, por exemplo, a epidemia de febre amarela em 1889 que durou de março a março dizimando 750 pessoas, ou seja, quatro por cento da população que permaneceu na cidade (ANDRADE, 1989; GITAHY, 1992; LANNA, 1996). Acreditase que o estopim da epidemia de "peste negra" (febre amarela) tenha sido o revolvimento do lodo putrefato acumulado na região do "porto do Bispo" ou "praia do Consulado", onde eram despejados os resíduos da cidade. Isso aconteceu em 
virtude da derrubada de um estaleiro da marinha para dar início às obras de construção do cais. A descrição a seguir, demonstra a calamidade que tomou conta de Santos:

"Foi uma tragédia coletiva: o Mosteiro de S. Bento virou hospital, bem como o Theatro Rink, a Beneficência abriu as portas, a Cruz Vermelha atendia à domicílio, os corpos eram transportados por carrinhos ao cemitério, que permanecia aberto à noite e as redações dos jornais viraram postos de informação. Os mais abastados haviam deixado a cidade e a população que ficou foi sendo vitimada. A crise só terminou em maio, com um saldo de 700 mortos." 7

CUNHA e AZEVEDO NETTO (apud ANDRADE, 1991, p. 63) apresentam os dados sobre o número de vítimas da febre amarela: em 1873 - 140 vítimas; em 1889 - 750 vítimas; em 1891 - 1.000 vítimas; em 1892 - 1.742 vítimas; em 1893 - 1.642 vítimas e em 1895 - 1.085 vítimas. Segundo LANNA (1996, p. 69), a primeira epidemia de febre amarela ocorreu em 1844, ou seja, antes do surto imigratório do final do século. A autora revela ainda que entre os anos de 1890 e 1900 em torno de metade da população morreu vítima das epidemias, ou seja, 22.588 pessoas. O ápice dos óbitos de todas as doenças, 4.173 mortes, ocorreu no ano de 1892 causados principalmente pela febre amarela, como demonstra GITAHY (1992, p. 35).

As epidemias, que já haviam se tornado freqüentes em Santos desde os anos 50 daquele século, colocavam em risco não só a entrada de imigrantes como também comprometiam o bom funcionamento do porto. Nesse período, o porto de Santos teve prejuízos consideráveis, já que muitos navios se

7 Trecho extraído do site Viva Santos, site oficial do município. Disponível em: http://www.vivasantos.com.br/01/01a.htm Acesso em: 15 de dezembro de 2006 
recusavam a atracar no chamado "porto da morte", local onde tripulações inteiras foram perdidas devido às epidemias que assolavam a cidade.

Entre os anos de 1894 e 1895, a linha do horizonte no mar acumulou um grande número de navios que, devido às obras do cais, aguardavam durante meses para atracar. Segundo GAMBETA, foi essa população embarcada a mais atingida pela febre amarela.

"Examinando o estado sanitário de Santos em 1895, a mando do governo francês, Voillot relatou ter pessoalmente contado mais de uma centena de barcos na enseada, à espera de novas tripulações que viessem substituir as sucumbidas." (GAMBETA, 1984, p. 18)

ANDRADE (1991) acredita que as reformas urbanas realizadas em Santos, ainda em fins do século XIX, ocorreram mais pelo fato da cidade ter se transformado em um foco irradiador de doenças para o interior do estado do que a uma importância estética buscada pela cidade em decorrência do seu crescimento econômico.

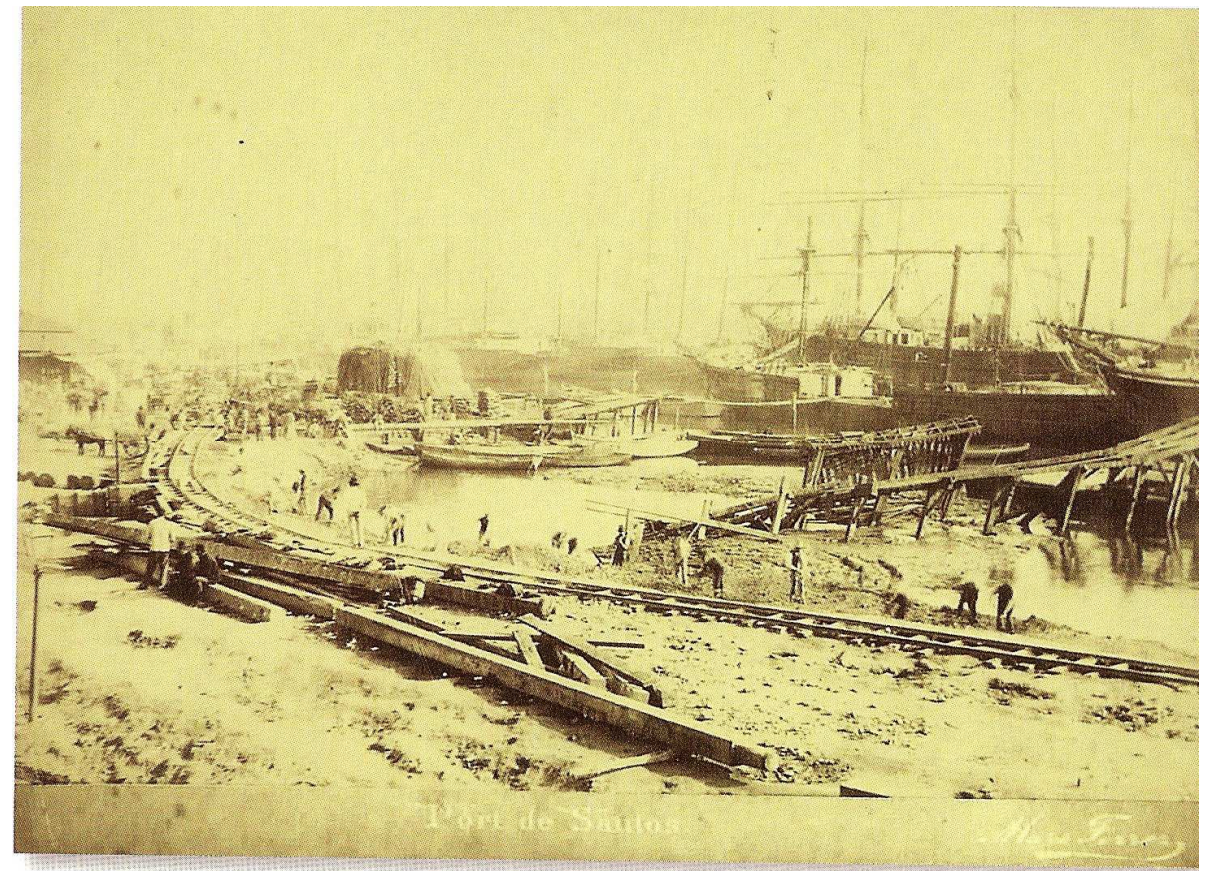

Figura 5: Porto do Consulado na década de 1880. Foto de Marc Ferrez (Acervo Biblioteca Mário de Andrade / fonte: CALDATTO, Gino. Santos e seus Arrabaldes - Álbum de Militão Augusto de Azevedo. São Paulo: ed. Magma Editora Cultural, 2004) 
É nesse momento de transformação do espaço urbano santista que a Avenida Conselheiro Nébias é efetivamente ocupada. Desde sua abertura oficial em 1867, por iniciativa do engenheiro de ferrovias Ignácio Wallace da Gama Cochrane $^{8}$, a avenida funcionava como ligação entre o centro e as chácaras de veraneio concentradas, inicialmente, na atual praia do Boqueirão. O percurso de 6 quilômetros entre o cais e a Barra era feito através de uma linha de bondes inaugurada em outubro de 1872, ainda puxados por muares, substituídos por bondes elétricos apenas em 1909. Segundo ANDRADE (1989), na zona intermediária entre o atual centro e a Barra havia um enorme espaço vazio, alagadiço, revestido apenas com vegetação baixa.

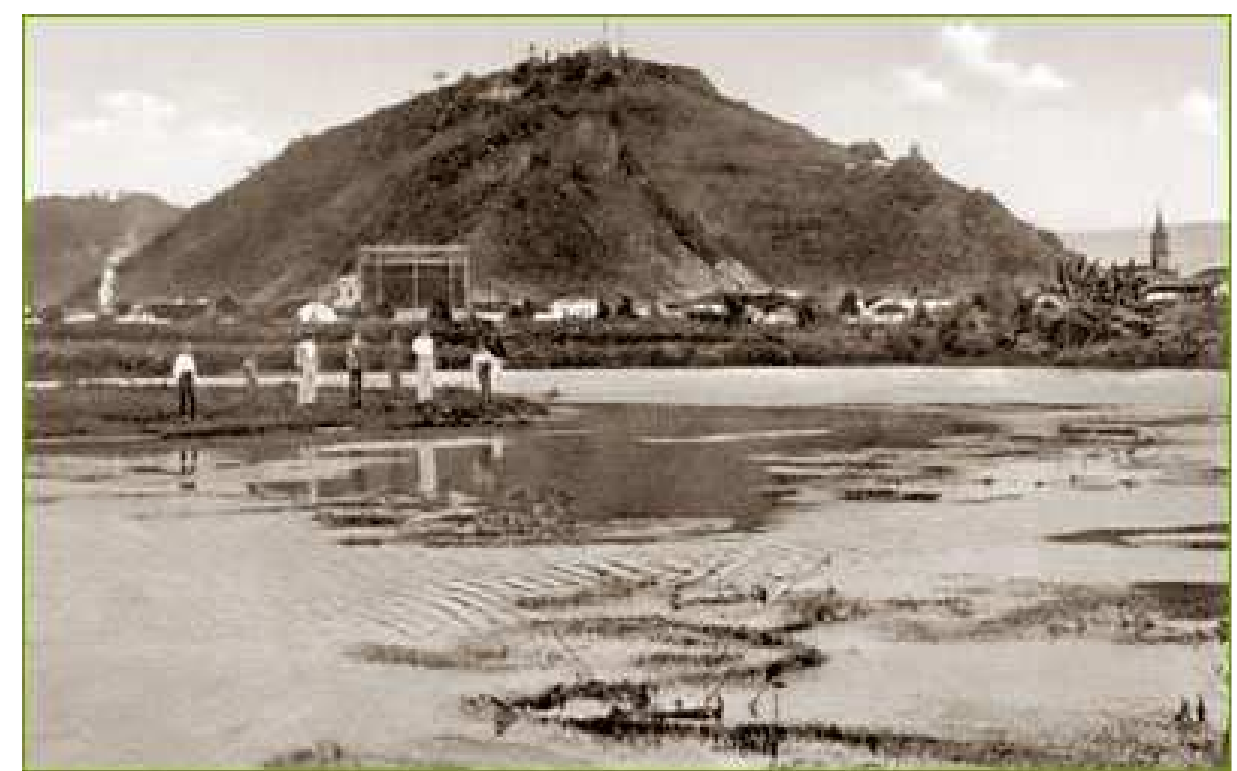

Figura 6: A zona do Outeirinhos, entre Macuco e Vila Mathias - alagadiços antes das drenagens. (Coleção João Gerodetti / fonte: Prefeitura Municipal de Santos)

A Avenida Conselheiro Nébias, no entanto, foi a precursora da concretização desse ideal em Santos, funcionando como referência tanto para a Avenida Ana Costa, outro eixo importante construído cerca de 20 anos mais tarde, quanto para o plano de Saturnino de Brito para Santos. Todavia, essas

\footnotetext{
${ }^{8}$ Segundo ANDRADE (1989), Ignácio Wallace da Gama Cochrane teve várias vinculações com Santos: comissário de café, membro da Associação Comercial de Santos e presidente da Câmara Municipal.
} 
transformações na estrutura da cidade foram proporcionadas pelo desenvolvimento da economia cafeeira do Oeste Paulista que culminou com a construção da ferrovia São Paulo Railway, inaugurada em 1867, ligando as zonas produtoras de café e a capital paulista ao litoral.

\section{I.4. A expansão para a Barra e a Avenida Conselheiro Nébias.}

Antes da construção da avenida, o trajeto até a Barra era feito por um caminho sinuoso que ia desde o Largo da Matriz, atual praça da República, até a praia num ponto chamado de Boqueirão. Com a abertura da Avenida Conselheiro Nébias, que fazia esse percurso em linha reta, o antigo caminho passa a ser conhecido como Caminho Velho da Barra. Esse caminho existe ainda hoje constituído pelas ruas Brás Cubas, avenida Washington Luiz (o canal 3), rua Luís de Camões, atingindo a praia do Boqueirão pela rua Oswaldo Cruz. ${ }^{9}$ No ponto onde o Caminho Velho da Barra cruza com a avenida Conselheiro Nébias, que passa a ser conhecida na época como Caminho Novo da Barra, nasceu o bairro chamado de Encruzilhada.

A instalação dos serviços de bonde na avenida, construída em 1867, inicia o processo de ocupação efetiva da Barra uma vez que a região das praias era até então ocupada apenas por chácaras onde as famílias tradicionais e de posse passavam alguns períodos do ano. Poucas eram as famílias que realmente moravam nessa região antes da instalação das linhas de bonde, em 1872, já que a praia era desvinculada da cidade devido à dificuldade de acesso.

\footnotetext{
${ }^{9}$ O canal 3 foi construído respeitando o caminho existente, assim como aconteceu em outros exemplos na cidade. Isso demonstra a aproximação de Saturnino às idéias de Camilo Sitte nos seus projetos de saneamento, como demonstram os trabalhos de ANDRADE (1992).
} 


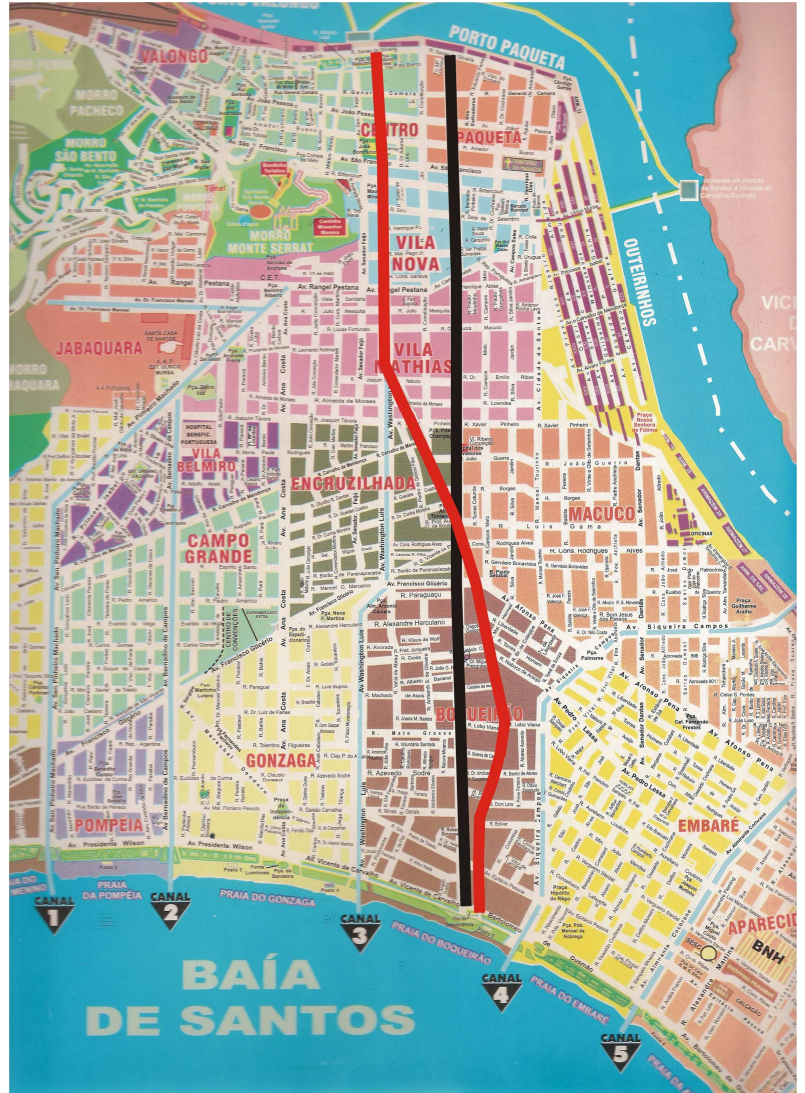

Figura 7: Caminho Velho da Barra destacado em vermelho e Caminho Novo da Barra (Avenida Conselheiro Nébias) destacada em preto. No cruzamento dos dois eixos tem-se o bairro Encruzilhada. (Fonte: Mapa de Santos, ed.: Solen Comunicação e Editora, 2003)

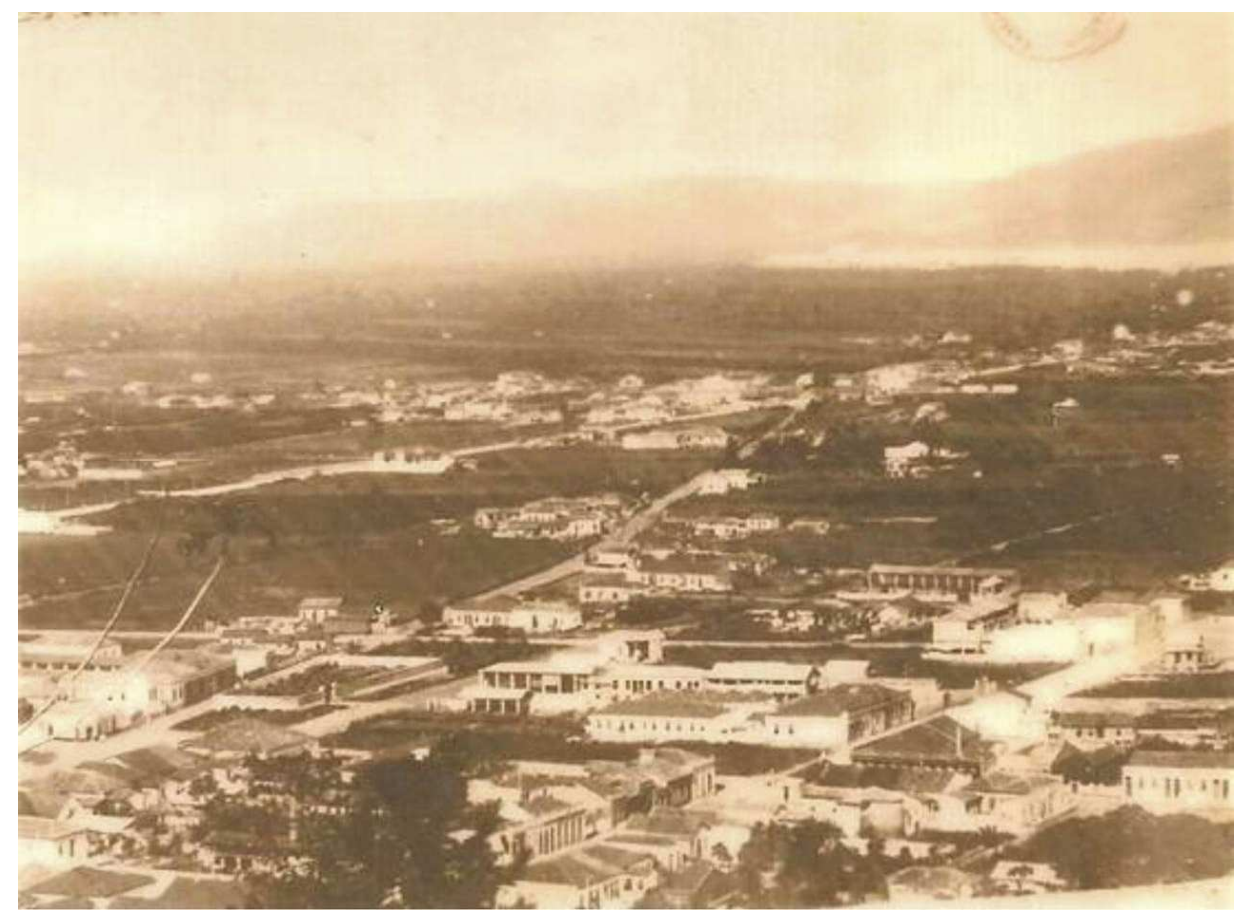

Figura 8: Confluência entre Caminho Velho e Caminho Novo da Barra no início do século XX. Foto: José Marques Pereira (Fonte: Site Novo Milênio - disponível em http://www.novomilenio.inf.br/santos. acesso em: fevereiro de 2006) 
Também se acrescenta a isso o fato de que a ocupação da região beira-mar é estimulada logo que práticas como banhos de mar ou exercícios na orla passam a ser associados à saúde, ao contrário do que se pensava anteriormente (CORBIN, 1989). A idéia de que a apropriação do mar e sua região limítrofe é benéfica consolida seu valor positivo na Europa somente a partir do primeiro quartel do século XIX, mas a falta de saneamento em Santos, assim como a lenta modernização dos costumes nos leva a pensar que ali, como em outras partes do Brasil, o "culto ao mar" tenha se atrasado alguns anos.

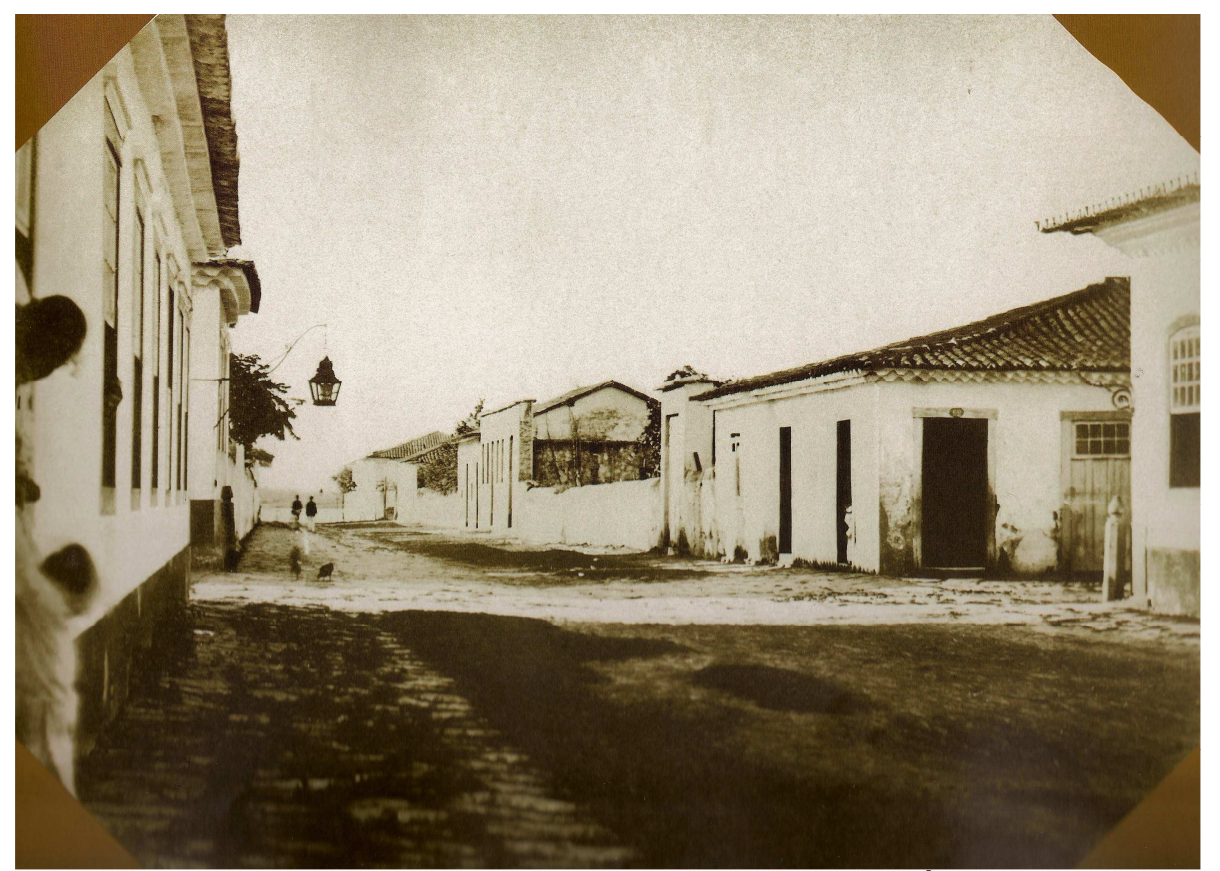

Figura 9: Caminho Velho da Barra esquina com a antiga rua Áurea, atual rua General Câmara, em 1865. Foto de Militão Augusto Azevedo tirada a dois quarteirões do porto com foco voltado para ele. (Acervo Instituto Moreira Salles / fonte: CALDATTO, Gino. Santos e seus Arrabaldes - Álbum de Militão Augusto de Azevedo. São Paulo: ed. Magma Editora Cultural, 2004).

Portanto, a Avenida Conselheiro Nébias aparece como um veio estrutural que canalizou efetivamente a expansão e a ocupação para a Barra, mesmo que a zona intermediária entre essas duas extremidades tenha sido ocupada posteriormente com os serviços de drenagem comandados inicialmente pelo 
engenheiro Fuertes e concluídos com os canais de Saturnino, que sanearam a região intermediária entre a praia e o centro velho.

"Em Santos, ao mesmo tempo que a cidade e o porto se distanciavam, as ações de saneamento iam definindo um novo espaço urbano privilegiado: a beira-mar. Entre ela e a velha cidade alguns quilômetros de terras livres, e após 1913, saudáveis para serem devidamente incorporadas pela especulação imobiliária”. (LANNA, 1996, p. 107)

Em 1907, entrava em vigor a Lei 265 de 05 de junho que tinha por objetivo intensificar as construções e o povoamento das avenidas Conselheiro Nébias e Ana Costa, construída posteriormente. Para isso, a proposta do governo era de isentar de impostos por um ano os prédios que fossem construídos ao longo dessas avenidas.

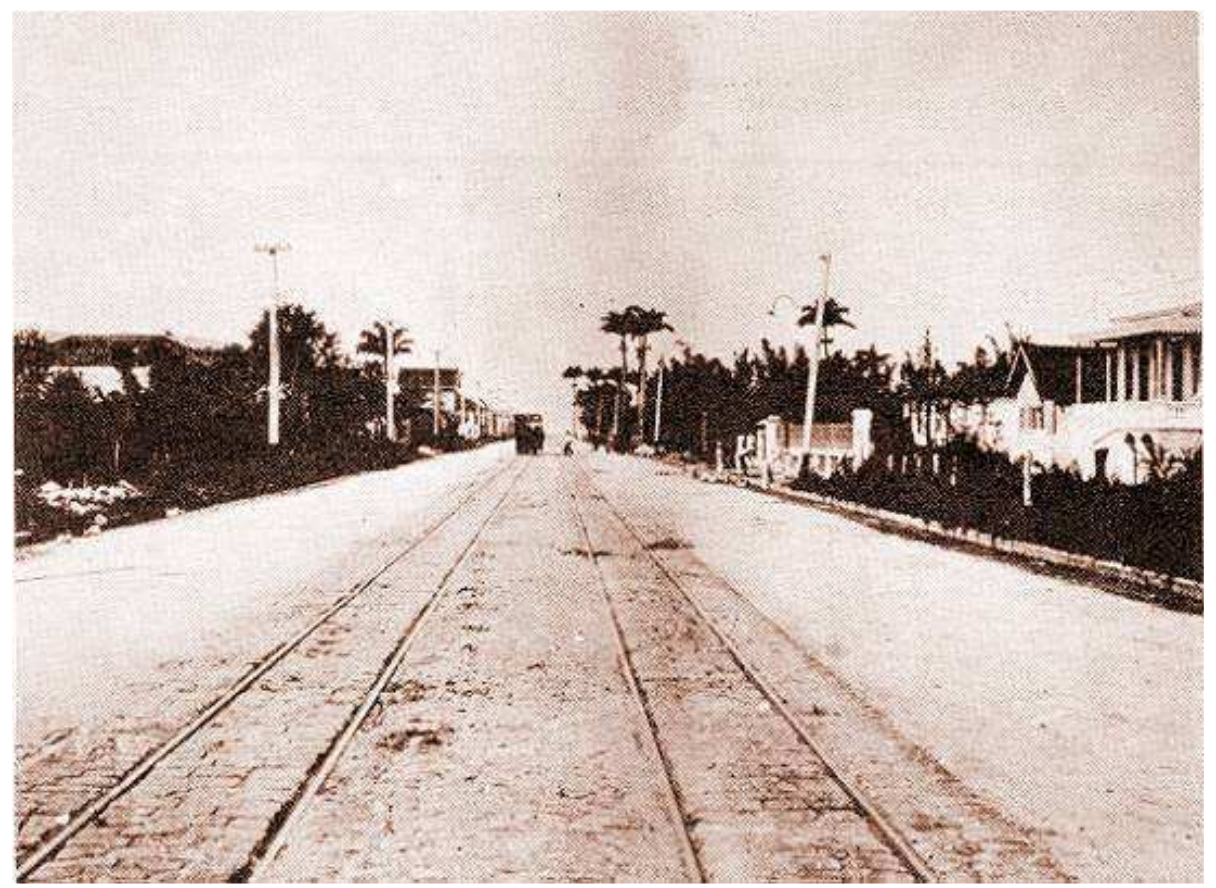

Figura 10: Avenida Conselheiro Nébias no trecho próximo à Barra, em 1904. (Fonte: disponível em <http://www.novomilenio.inf.br/santos/fotos036.htm> acesso em janeiro de 2006)

As construções deveriam demonstrar o ideal de beleza associado à salubridade que se buscava. Nesse sentido, em 03 de janeiro de 1912 foi promulgada a Lei 489, o primeiro esboço do Código de Obras separado do Código 
de Posturas, que trazia os recuos obrigatórios para as construções nessas avenidas, assim como áreas mínimas de compartimentos, iluminação e ventilação. Além disso, estipulava regras de altura mínima para a construção de porões (NUNES, 2001).

Enquanto a população pobre era empurrada para os arrabaldes da cidade, onde eram tolerados e conseguiam escapar das visitas domiciliares dos inspetores sanitários e, ao mesmo tempo, do fisco municipal, a cidade moderna era constituída por bulevares e jardins, com rede de esgoto e fornecimento de água e luz.

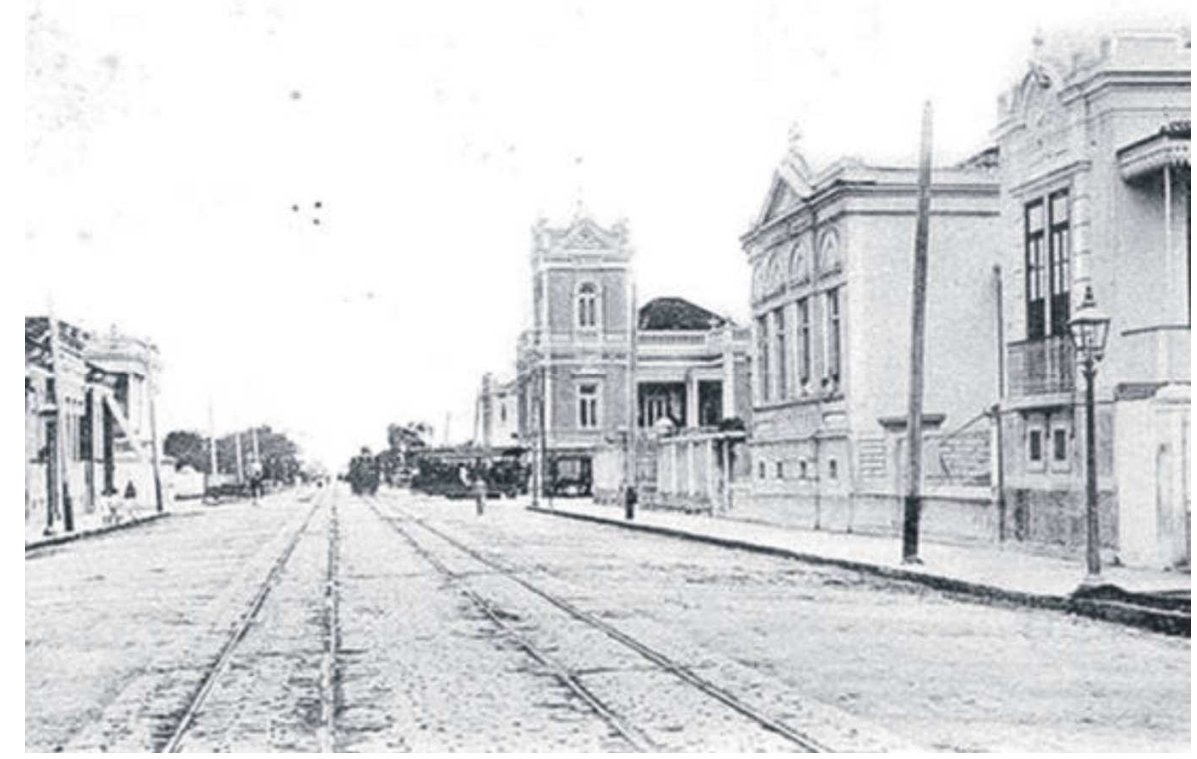

Figura 11: Avenida Conselheiro Nébias na altura do bairro Vila Nova, em 1910. Foto: coleção do cartofilista e despachante aduaneiro Laire José Giraud.

(Fonte: site Novo Milênio - disponível em: http://www.novomilenio.inf.br/santos. Acesso em: janeiro de 2006)

Com a transformação da imagem da cidade vieram também novos hábitos e costumes incorporados pela elite que ocupava a orla, demonstrando a consolidação dos valores burgueses. LANNA (1996) cita como exemplos o aparecimento de esportes, cinema, footing à beira-mar e bailes. Foi ao longo dos 3.864 metros de comprimento da Avenida Conselheiro Nébias, longa, larga e reta, que se desenvolveu a prática do ciclismo pela elite da cidade; "não era considerado 
elegante o rapaz de boa sociedade que não tivesse uma bicicleta”, acrescenta LANNA (1996, p. 147).

No entanto, após a consolidação da elite na orla, os antigos bairros centrais e o trecho inicial da avenida, onde se instalou essa população num primeiro momento, passaram a ser ocupados por trabalhadores e pequenos comerciantes, sendo os antigos casarões transformados em cortiços ou tendo alguns dos cômodos alugados a estranhos pelas famílias que passaram a ocupá-los, como foi o caso do bairro Paquetá.

"O prolongamento do cais do porto, construído pela Cia. Docas de Santos, até o Paquetá, transformou, para pior, o bairro que era a área residencial mais aprazível da cidade. Contribuiu também para a desvalorização dele a construção do cemitério do Paquetá". (ANDRADE, 1989, p. 169)

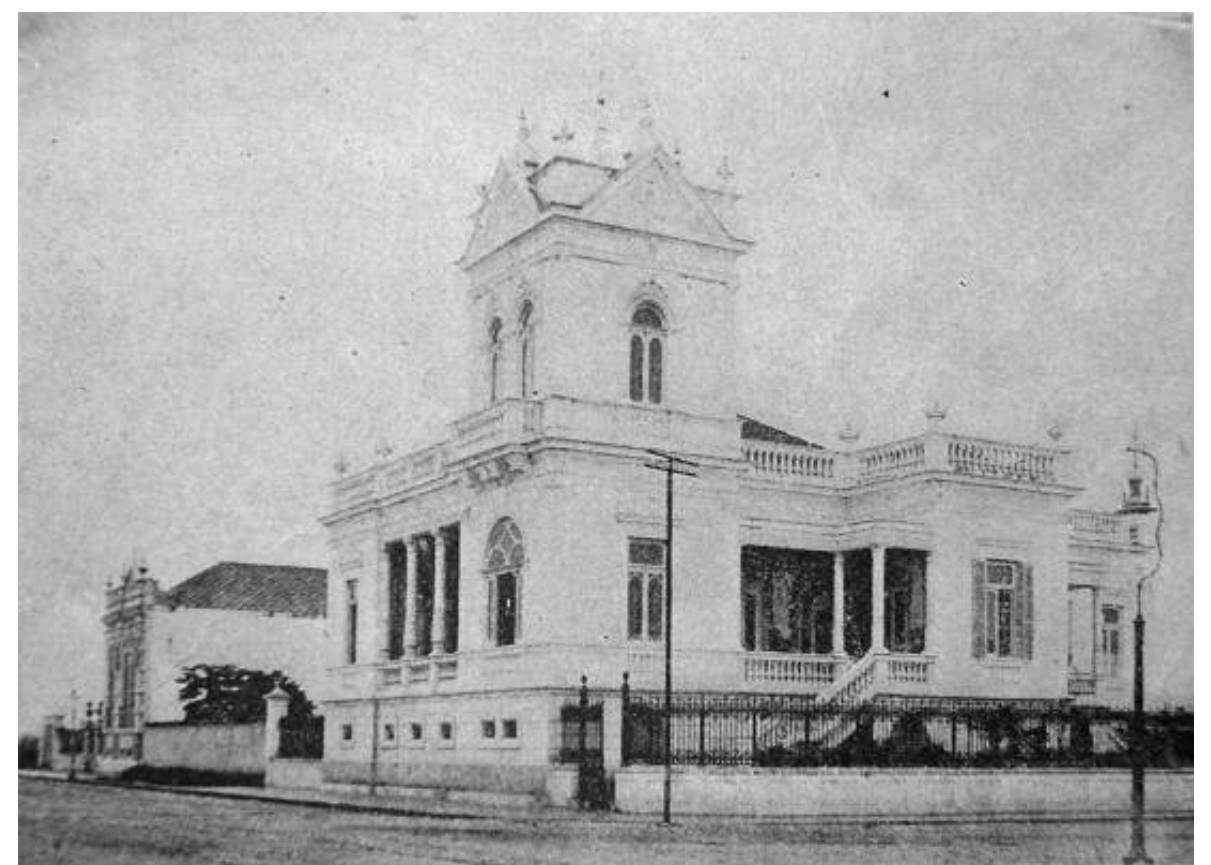

Figura 12: Construído na esquina da Rua Sete de Setembro com a Avenida Conselheiro Nébias, no bairro Paquetá, o palacete J. Carneiro Bastos foi o primeiro palacete de Santos. (Fonte: site Novo Milênio - disponível em http://www.novomilenio.inf.br/santos/fotos240.htm acesso em: janeiro de 2006) 
O mesmo aconteceu com a Vila Nova, também ocupada por segmentos sociais de baixa renda ${ }^{10}$ e que, ao longo do tempo, consolidou seu caráter de bairro comercial e de pequenas indústrias, deixando de ser exclusivamente residencial. Outro fator que contribuiu para seu esvaziamento populacional foi a explosão de um dos cinco reservatórios do gasômetro ${ }^{11}$ por desgaste de instalações, destruindo dezenas de prédios da redondeza.

Atualmente, no percurso desde o Porto até a praia, a avenida atravessa o bairro do Paquetá, Vila Nova e Vila Mathias, delimita à direita o bairro da Encruzilhada e à esquerda o bairro do Macuco e, avançando pelo bairro do Boqueirão, alcança a praia de mesmo nome. É aproximadamente na metade da sua extensão que a avenida é cortada perpendicularmente pela linha do trem, fazendo com que seja dividida em duas partes com características bem diferentes quanto à população moradora e à valorização urbana.

O que vemos surgir são dois vetores distintos que coordenavam o crescimento urbano no período: de um lado o vetor da exclusão ao qual pertenciam os trabalhadores, os imigrantes e os ex-escravos que passaram a ocupar a região central da cidade, as encostas dos morros e os arrabaldes mais próximos ao perímetro urbano. O vetor da exclusão compreende as zonas norte e noroeste de Santos e um pouco da zona central, que se torna quase que exclusivamente comercial. De outro lado, o vetor da valorização fundiária seguia os investimentos imobiliários ao longo da Avenida Conselheiro Nébias seguindo em direção à praia da Barra, onde surgiam os primeiros casarões e palacetes da elite, além dos hotéis e

\footnotetext{
${ }^{10}$ O número de habitantes regrediu em função da construção do mercado municipal, em 1950.

${ }^{11}$ Depósito da Cidade de Santos - Serviços de Eletricidade e Gás S/A, ficava na Rua Marechal Pego Júnior, $n^{\circ} .144$ (MONDIN, 2006)
} 
dos clubes de luxo que transformavam a orla em um núcleo de lazer da nova cidade "modernizada". Esse vetor abarcava a zona sul santista.

Portanto, a expansão urbana de Santos foi marcada pela cisão da cidade em dois núcleos sociais pelas Reformas Urbanas, pois na medida em que estas empurravam a população pobre para a periferia também criavam condições de ocupação e valorização da orla. Essas transformações que ocorreram na cidade foram comandadas pelo Estado, patrocinadas pelo capital oriundo do apogeu da economia cafeeira, como se verá a seguir.

\section{I.5. A crise da economia brasileira e a primeira fase do café.}

$\mathrm{Na}$ primeira metade do século XIX, a tendência da economia brasileira foi declinante ${ }^{12}$. O estancamento das exportações tornou-se o principal motivo do atraso da economia brasileira nesse período, fazendo-se necessário que o país encontrasse produtos que o reintegrasse ao comércio internacional.

Nesse período, o café que desde o começo do século XVIII já vinha sendo cultivado no Brasil $^{13}$ para consumo local, apresentando boa adaptação às

\footnotetext{
${ }^{12}$ Como demonstrou Furtado (2001), a mineração estava em decadência, o valor das exportações de algodão se reduziu a metade, assim como o das de couro e peles; o valor das exportações de fumo permaneceu estacionado. O mercado do açúcar enfraqueceu em decorrência da produção do açúcar de beterraba pelo continente europeu e do surgimento de outro fornecedor ao mercado norte-americano: Cuba. A forte baixa dos preços dos tecidos ingleses impossibilitava a sobrevivência da pequena produção do artesanato têxtil local, que não conseguia competir com as tarifas inglesas nem mesmo dentro do Brasil. Além disso, também havia o problema da insuficiência de escravos devido ao combate inglês ao tráfico internacional, desde o início do século XIX, culminando na extinção definitiva do tráfico negreiro no Brasil em 1850 (Lei Eusébio de Queiroz).

${ }^{13}$ Inicialmente, o café ocupa a região montanhosa próxima ao Rio de Janeiro, onde era então comercializado. A localização das primeiras fazendas de café nas proximidades do Rio se dá, assim como no caso do ouro, em conseqüência da proximidade do porto, fator imprescindível considerando que o transporte da mercadoria era feito através de mulas. Além disso, havia uma grande adaptabilidade ao clima e ao solo e relativa abundância de trabalhadores disponíveis em virtude da desagregação da economia mineira. Dessa forma, diversos autores concluem que a primeira fase da economia cafeeira se deve mais pela utilização de recursos internos preexistentes
} 
condições ecológicas do país, passa a ter importância comercial principalmente em decorrência da desorganização da colônia francesa do Haiti, então a maior produtora do gênero (FURTADO, 2001).

A empresa cafeeira foi financiada por grupos familiares provindos da mineração que emprestavam dinheiro, mediante hipotecas, aos agricultores que queriam expandir seus cafezais. Posteriormente, esses grupos familiares transformaram-se em casas comissárias estabelecidas nos portos, vendendo o café e abastecendo seus clientes de outros produtos de consumo.

Sobre a entrada do café em São Paulo, Taunay (apud SZMRECSANYI, 1984) afirma que, na passagem para o século XIX, as primeiras sementes de café já haviam sido levadas a Santos, Itu e Jundiaí, atingindo a região de Campinas, pelo governo colonial português na tentativa de disseminá-lo. Esse fato somado ao capital gerado pela venda das mulas liberadas pela construção da linha férrea Santos-Jundiaí - fundo este aplicado na produção cafeeira (GRANZIERA apud SZMRECSANYI, 1984), é que deram origem às plantações de café do Oeste Paulista.

Um dos empecilhos para a expansão do cultivo do café era a distância até o porto, já que o meio de transporte utilizado era feito por mulas, o que não permitia um avanço muito além do litoral. Assim, o desenvolvimento do café nos arredores de Campinas criou a necessidade de um sistema de transporte que transpusesse $200 \mathrm{~km}$ (MONBEIG, 1984). Outro fator que desfavorecia o transporte 
por mulas era o custo gerado pelas tropas, haja vista sua manutenção onerosa e as perdas da carga de café por eventuais intempéries.

Esses percalços que atravancavam o avanço da propriedade agrícola e, consequentemente, a expansão da economia cafeeira só foram resolvidos com a construção do sistema ferroviário paulista, comandado e drenado pela São Paulo Railway - ligação entre Jundiaí e o porto de Santos inaugurada em 1867, (MILLIET, 1982; MONBEIG, 1984; SZMRECSANYI, 1993).

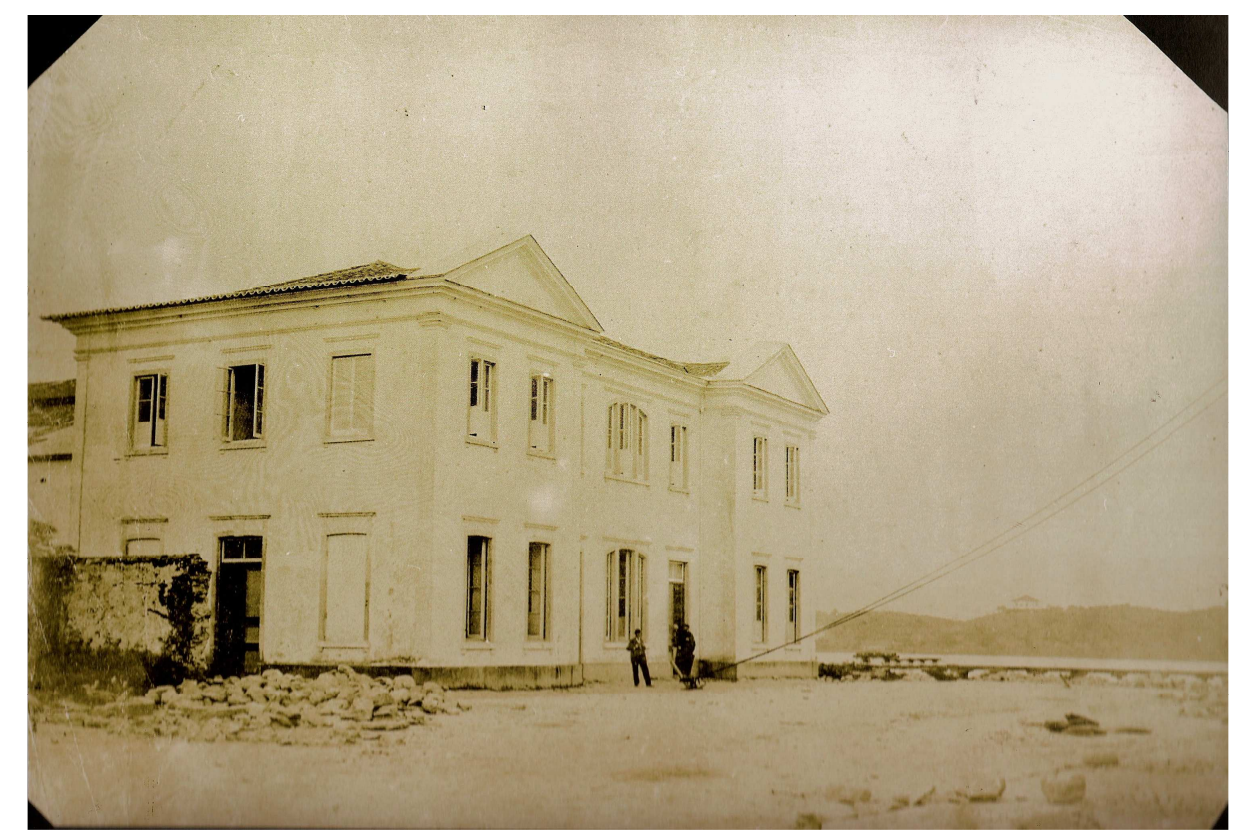

Figura 13: Estação de trem da São Paulo Railway Co., em 1865. Construída no bairro do Valongo no local do antigo convento, entre o porto do Bispo e a Igreja dos Franciscanos, estava quase concluída no ano da foto. (Acervo Museu Paulista / fonte: CALDATTO, Gino. Santos e seus Arrabaldes - Álbum de Militão Augusto de Azevedo. São Paulo: ed. Magma Editora Cultural, 2004)

O porto de Santos passa a ser a grande porta de escoamento da produção do Oeste Paulista, que rapidamente superava a produção fluminense ${ }^{14}$. A construção da rede ferroviária, iniciativa da burguesia paulista do café em

${ }^{14}$ A decadência das fazendas fluminenses advém do atraso do seu sistema de transportes que continuou a ser feito por muares, lento e oneroso, lembrando que Mauá adiou por várias vezes a construção da ferrovia no Rio de Janeiro. Soma-se a isso, a quebra dos comissários de café do Rio e, consequentemente, dos fazendeiros, o que culminou com redução do crédito internacional e, por conseguinte, com a impossibilidade de substituir a mão-de-obra escrava, que após sete ou oito anos de atividade nas fazendas já se tornavam improdutivos. 
associação ao capital britânico e garantia do Estado, permitiu aos agricultores expandir a produção pelo interior do estado (MONBEIG, 1984), que se deu obedecendo duas condicionantes: evitar a linha do trópico para minimizar as geadas e avançar sobre as grandes florestas de terra virgem ${ }^{15}$.

\section{I.6. Santos e a força de trabalho.}

A partir da metade do século XIX, o problema da força de trabalho assolava não só os fazendeiros fluminenses como também os do Oeste Paulista. O trabalho era realizado basicamente por escravos que, em 1872, somavam cerca de 1,5 milhão, ou seja, praticamente a mesma quantidade existente no início do século, demonstrando um crescimento quase nulo. Esse fato evidencia que a taxa de mortalidade era superior à de natalidade, tendo em vista que nos primeiros cinqüenta anos desse século se importou mais ou menos meio milhão de escravos. Ainda assim, aqueles existentes em São Paulo localizavam-se em maior quantidade nos velhos centros cafeeiros ${ }^{16}$, como o vale do Paraíba e, em menor proporção, em Campinas (FURTADO, 2001; MONBEIG, 1984).

\footnotetext{
${ }^{15}$ Segundo Milliet (1982), o café foi se expandindo obedecendo as condicionantes que definiam o clima e buscando o solo mais adequado às mudas. A terra roxa era o tipo de solo no qual melhor se adaptavam as plantações de café. Era encontrada nos planaltos de Ribeirão Preto, Araraquara, Jaú, São Manoel e ao longo do vale do Paranapanema, nos municípios de Piraju, Xavantes e Ipauçu, aparecendo em maiores extensões no norte do Paraná. Assim, o café adentrou o estado de São Paulo, acompanhando as linhas férreas, até alcançar o norte do Paraná.

${ }^{16} \mathrm{Em}$ outras partes do Brasil havia possibilidade de encontrar trabalhadores, no entanto, a maioria da população vinculada a terra estava retida a ela por um sistema de auto-subsistência, ou seja, o trabalhador podia explorar a terra concedida pelo latifundiário para sua subsistência, mas em contrapartida deveria trabalhar para ele a troco de uma pequena parte da colheita. Assim, apesar de não serem donos de nenhuma propriedade e de contarem apenas com sua força de trabalho, esses trabalhadores ficavam ligados aos latifúndios porque era dali que tiravam sua subsistência (SILVA, 1985). A outra parte da população era aquela proveniente das zonas urbanas que não encontrava ocupação freqüente e que poderia ser deslocada para as fazendas do café. Entretanto, o recrutamento interno no Brasil, financiado pelo governo, teve menos possibilidade de evoluir do que um programa de importação de trabalhadores estrangeiros.
} 
Iniciativas inovadoras para solucionar o problema da escassez de força de trabalho vieram do espírito empreendedor da burguesia como de um fazendeiro de Limeira, o Senador Vergueiro, um dos precursores na iniciativa de recorrer a trabalhadores livres para as novas regiões do café. Entretanto, o modelo de contrato de colonos proposto pelo Senador constituía um sistema de escravidão disfarçada e devido à reação européia, teve de ser substituído.

Somente no final da década de 60 , quando os fazendeiros se viram pressionados em alta procura do café e escassez da oferta de escravos, procuraram oferecer condições de trabalho baseadas em contratos salariais.

O problema seguinte foi o do pagamento da viagem dos colonos. $\mathrm{O}$ sistema antigo, segundo o qual o próprio colono deveria indenizar os gastos com sua viagem, culminaria no mesmo regime de escravidão disfarçada, já denunciado. No entanto, se essa despesa recaísse sobre o fazendeiro somente os mais ricos poderiam promover a imigração. A solução para esse impasse veio quando o governo imperial passou a arcar com os custos de transporte dos imigrantes, no ano de 1870. Ao fazendeiro cabiam as despesas do colono no primeiro ano de trabalho, quando esse ainda estava se adaptando, além de colocar terras à disposição do imigrante onde pudesse cultivar gêneros de subsistência ${ }^{17}$.

Percebe-se que o Estado está intrinsecamente vinculado ao desenvolvimento dessa economia, o que se explica pelo fato da burguesia cafeeira de São Paulo ter o governo não só da província, mas do Estado brasileiro dois anos

\footnotetext{
${ }^{17}$ Com o custeio dos gastos iniciais, o fluxo imigratório teve um crescimento espantoso pela primeira vez na América, sobretudo de italianos da região sul da Itália, o chamado reino das Sićlias, devido a Unificação Nacional que desencadeou um processo de crise econômica nessa região. Segundo Furtado (2001), o número de imigrantes europeus que entraram no estado de São Paulo subiu de 13 mil, em 1870, para 184 mil, em 1880 e 609 mil, em 1890, chegando a um total de 803 mil no último quartel do século, dos quais $72 \%$ eram provenientes da Itália.
} 
após a República, utilizando o governo como instrumento de ações econômicas de seu interesse. Para Furtado essa atuação diferenciou essa classe de outras elites anteriormente dominantes no país, pois, embora vinculada a financiamentos e ao mercado de consumo externos - de onde provinham seus estímulos originais, gerou pela introdução da mão de obra livre a formação de uma economia capitalista com dinamismo interno. Nesse sentido complementa Szmrecsanyi:

“(...) a burguesia emergente de São Paulo aprendeu a enxergar o café como um conjunto de atividades econômicas interligadas, às quais políticas especificas de Estado poderiam ser de grande estímulo por aumentar os lucros privados através de recursos públicos. Ao mesmo tempo, há varias evidências de que essa burguesia foi também rápida em definir alianças e oposições com outros grupos socioeconômicos e dentro de suas próprias fileiras." (SZMRECSANYI, 1993, p. 211)

Portanto, foi no último quartel do século que o trabalho livre assalariado foi efetivado no Brasil, com o apogeu da economia cafeeira decorrente da construção da ferrovia São Paulo Railway e suas conseguintes ampliações para o interior do estado, somadas à iniciativa de promover a imigração. Esse dinamismo passa necessariamente por Santos, no embarque do café, nas casas exportadoras ali sediadas, na mão de obra imigrante.

Com o avanço da acumulação interna de capital, tem-se o surgimento de uma nova dinâmica social dentro da cidade. A burguesia se consolida e outros seguimentos sociais emergem como os trabalhadores estrangeiros e nacionais e os ex-escravos. A cidade é invadida por novas práticas sociais, novas formas de moradias e novos surtos de epidemias. Assim sendo, o convívio entre esses grupos influenciou diretamente os modos de ordenar o espaço urbano. 


\section{I.7. A formação de uma nova sociedade.}

Desde a metade do século XIX, com o desenvolvimento da economia cafeeira, Santos havia se tornado a sede do porto que monopolizava quase toda a atividade do planalto. Essa vitalidade do porto somada à construção da ferrovia permitiu consolidações e transformações nas funções portuária e comercial. As redondezas da estação se caracterizavam, pouco a pouco, como áreas comerciais, já que ela se tornara ponto de encontro da população (LANNA, 1996). Ao mesmo tempo, as elites locais passaram a abandonar a parte mais rica e nobre da cidade, o bairro do Valongo, e começaram a se transferir para novas áreas que vão surgindo gradativamente.

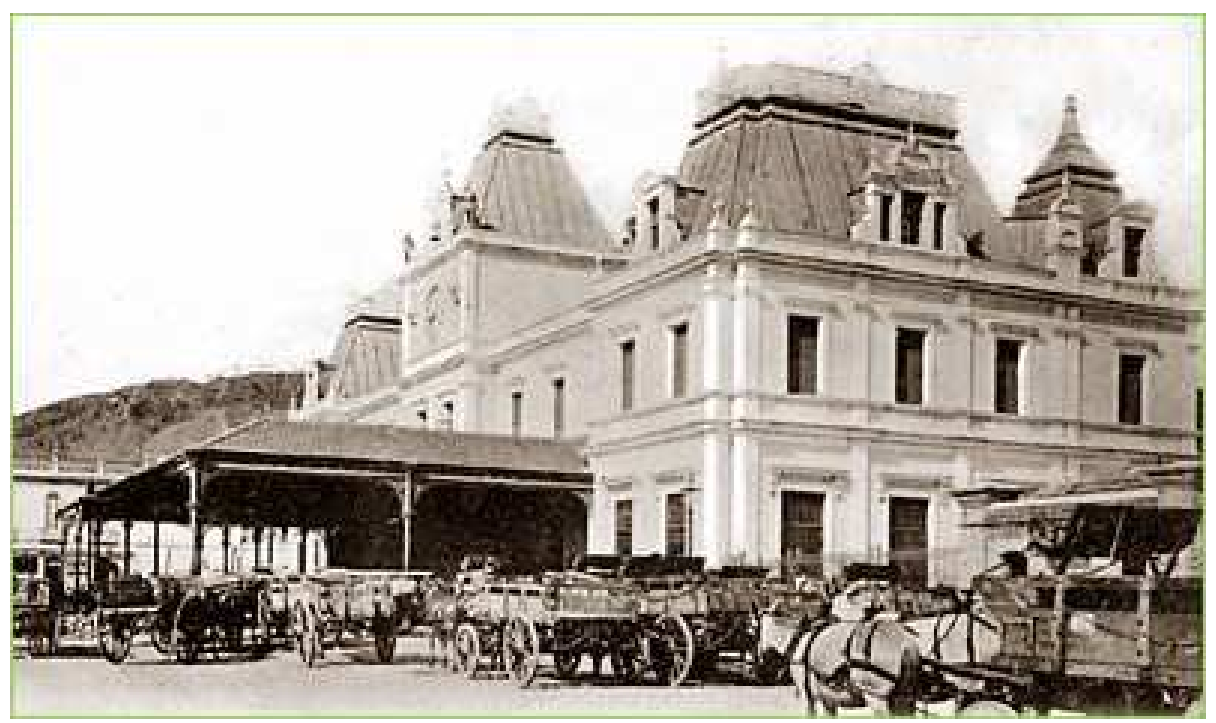

Figura 14: Estação da São Paulo Railway no bairro do Valongo, em 1905. Carroças aguardam a chegada do café para transportá-lo aos armazéns.

(Fonte: Prefeitura Municipal de Santos)

Nas redondezas da Avenida Conselheiro Nébias surgem bairros que aos poucos vão validando seu caráter nobre, propícios para acolher as elites que fugiam do tumultuoso núcleo urbano central. O bairro do Paquetá foi o primeiro a ser formado para fora dos perímetros do centro e ocupado pelas famílias tradicionais da cidade. Esse momento é descrito por Andrade como marco inicial da expansão 
urbana que se deu "com a saída dos mais abastados para as residências que passaram a ser construídas no Paquetá, ou para as chácaras da Barra, onde se tornaram predominantes, até pelo menos 1910" (ANDRADE, 1989, p. 161).

Outro refúgio da elite foi o bairro Vila Nova, que também surgiu beirando a Avenida Conselheiro Nébias. Para lá se mudaram a elite ligada ao café, advogados de renome, comerciantes ricos e, aos poucos, os palacetes foram se multiplicando. Moravam no bairro: João Otávio dos Santos, idealizador da escola técnica Escolástica Rosa; João Freire, famoso advogado da Companhia Docas; Delfim Novo, cônsul português, e a tradicional família Pacheco.

A Avenida Conselheiro Nébias, onde também se instalou parte dessa elite, era o local em que se concentravam as atividades de lazer e o cenário bucólico onde se via surgirem hábitos e costumes dessa nova sociedade, como o footing, por exemplo.

"E tudo ficava muito poético quando a noite caía e os lampiões lançavam sua luz amarelada sobre as construções altaneiras e bem cuidadas. O som dos pianos enchia o ambiente, porque não havia casa sem piano e moça que não soubesse tocar esse instrumento. Os saraus avançavam noite adentro e ai que algum pai flagrasse uma das filhas na sacada de mãos dadas com o namorado. As moças nunca saíam sozinhas, nem mesmo para ir ao cinema que ficava bem perto, na Conselheiro Nébias, altura da 7 de Setembro. Estavam sempre acompanhadas pela mãe ou uma dama, sombrinha no ombro e leque na mão." 18

Entretanto, a facilidade de locomoção entre Santos e São Paulo permitiu que uma parcela da elite preferisse se afastar dos riscos de morte por epidemias que afligiam a cidade, passando a residir na capital. Os comissários pegavam o trem que partia de São Paulo às 10 h30 e retornavam de Santos no trem

\footnotetext{
18 MONDIN, Leda. Vila Nova e a ironia dos contrastes. Disponível em:
} http://www.novomilenio.inf.br/santos/h0100b13.htm acesso em dezembro de 2006. 
das $16 \mathrm{~h} 00$, ou seja, Santos havia se tornado lugar de se fazer negócios, mas não um espaço onde fosse possível viver. Era "lugar de ganhar a vida, de estar de passagem", conforme explicita LANNA (1996, p. 56).

\section{I.8. A modernização do porto de Santos.}

No último quartel do século XIX, a elite ligada ao café se enriquecia cada vez mais com a intensa atividade do porto ${ }^{19}$. No entanto, com o aumento gradativo da atividade exportadora, as condições precárias do porto se tornavam um empecilho para o movimento do café. Não era o bastante apenas aumentar o escoamento da produção até Santos, como foi proporcionado pela ferrovia e suas ampliações. Era fundamental que o porto fosse dotado das condições fundamentais de funcionamento. A modernização do porto era reivindicação constante dos comerciantes e preocupação das autoridades, sendo freqüentes as discussões na Câmara e associações locais, além da situação ter se transformado em alvo de críticas da impressa devido ao descaso do governo estadual (MONBEIG, 1984; LANNA, 1996).

A situação do porto era calamitosa. Formavam-se filas de embarcações para atracar e, as que conseguiam, ancoravam a cem metros dos trapiches se ligando a eles por pontes de madeira, onde transitavam os trabalhadores e escravos com as sacas de café nas costas (GITAHY, 1992; LANNA, 1996). Em visita a Santos, o ministro da Viação Serzedello Correia descreve o estado em que o porto se encontrava:

\footnotetext{
19 Como demonstra GITAHY (1992), em 1860, o porto exportava 36.250 sacas de café, passando para 2 milhões em 1895, atingindo 13.130 .933 sacas em 1909, quando a exportação atingiu 53,5\% do movimento total do porto, sendo que o café representava $98,5 \%$ desse total.
} 
"Milhares e milhares de pilhas de madeiras apodreciam, inúmeros barris de vinho esvaziavam-se, maquinismos sem uso arruinavam-se. Os carroceiros faziam as mais espantosas exigências ao mesmo tempo que navios levavam oito, nove, dez meses, ano mesmo, para poderem fazer sua descarga...Quando a maré baixava ficava descoberto um lamaçal enorme que empesteava a cidade e ia constantemente levar ao Estado de São Paulo e à capital os germes da peste." (CORREIA apud LANNA, 1996, p. 58)

Até a década de 1890, o porto de Santos ainda era composto por inúmeros trapiches, muitos deles remanescentes do início do século XIX, quando os terrenos à beira-mar passaram a ser valorizados por causa das possibilidades que surgiam a partir das atividades de exportação do açúcar.

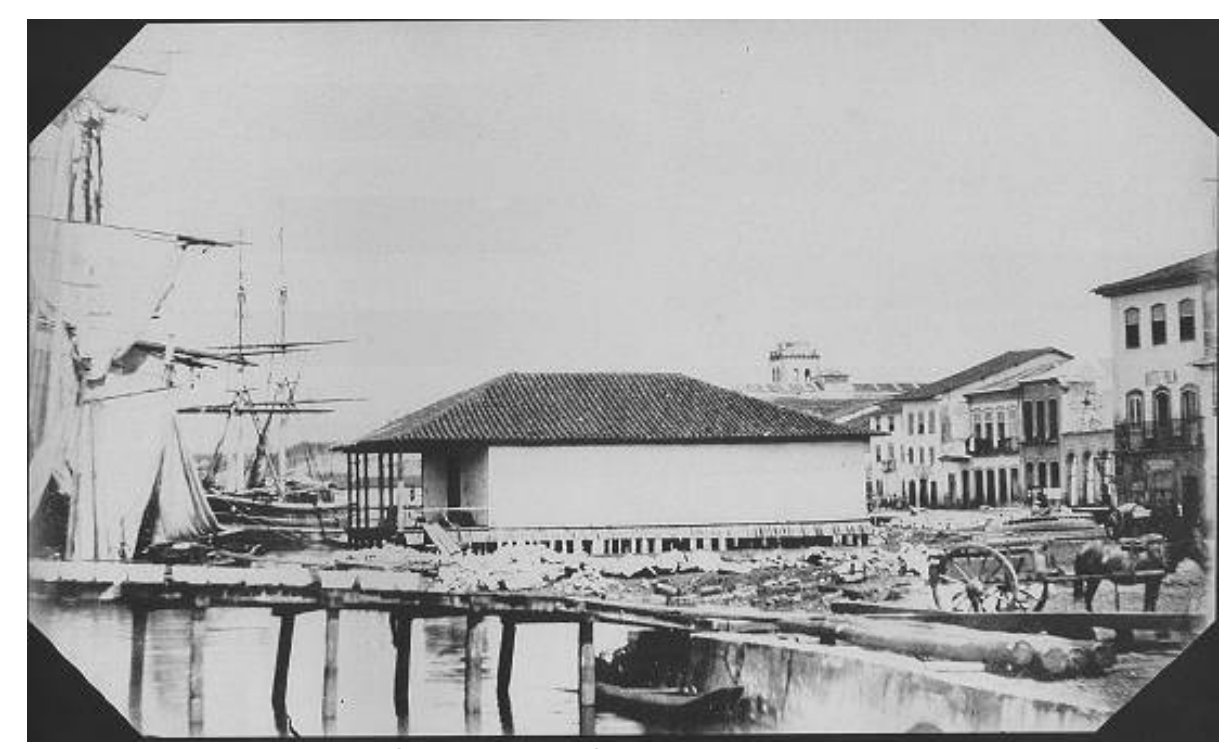

Figura 15: Porto do Consulado, foto de Militão Augusto de Azevedo.

(Fonte: CALDATTO, Gino. Santos e seus Arrabaldes - Álbum de Militão Augusto de Azevedo. São Paulo: ed. Magma Editora Cultural, 2004)

Inicialmente, a função de "porta ao mar" exercida por Santos desde a época de sua condição de vila acontecia por três ancoradouros: um ao pé da serra, o de Cubatão, outro situado na parte norte da Ilha de São Vicente, no lugar batizado com o nome português de Valongo, chamado de porto do Bispo, e outro um pouco mais adiante, no lagamar de Enguaguaçu, junto ao Outeiro de Santa Catarina, chamado de porto do Consulado. Nesses dois pontos, o de Santa Catarina e o do Valongo, formaram-se os primeiros núcleos de ocupação da Vila de Santos. A 
distância entre eles era de 35/40 minutos a pé, percorrida por um caminho que posteriormente se tornou a principal rua da vila, a rua XV de Novembro, inicialmente chamada de rua Direita, espinha dorsal da estrutura urbana inicial da vila (ANDRADE, 1995).

Como se viu, o porto necessitava de melhoramentos para suportar o aumento da movimentação que se deu a partir de 1867. Assim que, após inúmeras pressões, o governo imperial concedeu a construção do porto a Manoel Rodrigues Monteiro, o Conde Estrela, e ao cortesão Francisco Praxedes de Andrade Pertence, em 31 de agosto de 1870. A concessão foi dada por noventa anos, mas como nada fizeram, caducou em 1881.

"Elles não tinham dinheiro e precisavam levantar uma quarta parte dos 5.750 contos de réis para lançar acções do empreendimento. Correram nos ingleses da Caza Knuzles e Foster, de Londres, o que, em mi'a opinião, era o que já estava planejado desde o começo. Mas nem elles tiveram lá muita ganna por causa das doenças e foe tudo enrolado até o anno de 1881. Nem um metro de caes foe feito. O Imperador deu a concessão por caduca e não era sem tempo. E abriu, ou melhor quase abriu, porque ella de fato não aconteceu, uma concurrência. O governo da Província de São Paulo meteu-se assunto adentro e atrapalhou tudo, frenando a concurrência." 20

Após a infrutífera concessão ao Governo da Província de São Paulo, em 1886, o Governo Imperial retoma o direito sobre o porto. Logo em seguida foi aberta uma concorrência pelo Decreto $n^{\circ} 9.979$ vencida por um grupo de empresários, em 12 de julho de 1888. Os contratantes eram: José Pinto de Oliveira, Cândido Gaffrée, Eduardo Palassim Guinle, João Gomes Ribeiro de Avilar, Alfredo Camilo Valdetaro, Benedito Antônio da Silva, e Barros e Braga \& Cia.

"Mas a coisa estava caminhando tão feia que 14 dias depois do resultado montamos a empresa Gaffrée, Guinle e Cia. Vamos criar um facto

${ }^{20}$ GUINLE, Eduardo Palassim. A guerra que precedeu a batalha. In: Jornal da Orla, edição comemorativa ao $115^{\circ}$. aniversário do Porto de Santos, 02 de fevereiro de 2007. 
consumado, dizia eu aos sócios. A empresa levou nossos nomes porque elle (Gaffrée) botou mais dinheiro e eu porque fui quem organizei a coisa toda. Dizem que chutei para fora da empresa uma firma comercial chamada Barros \& Braga, que seria o segundo maior acionista isoladamente, mas isso não é verdade. Não gostava deles, mas não é verdade. Juro." 21

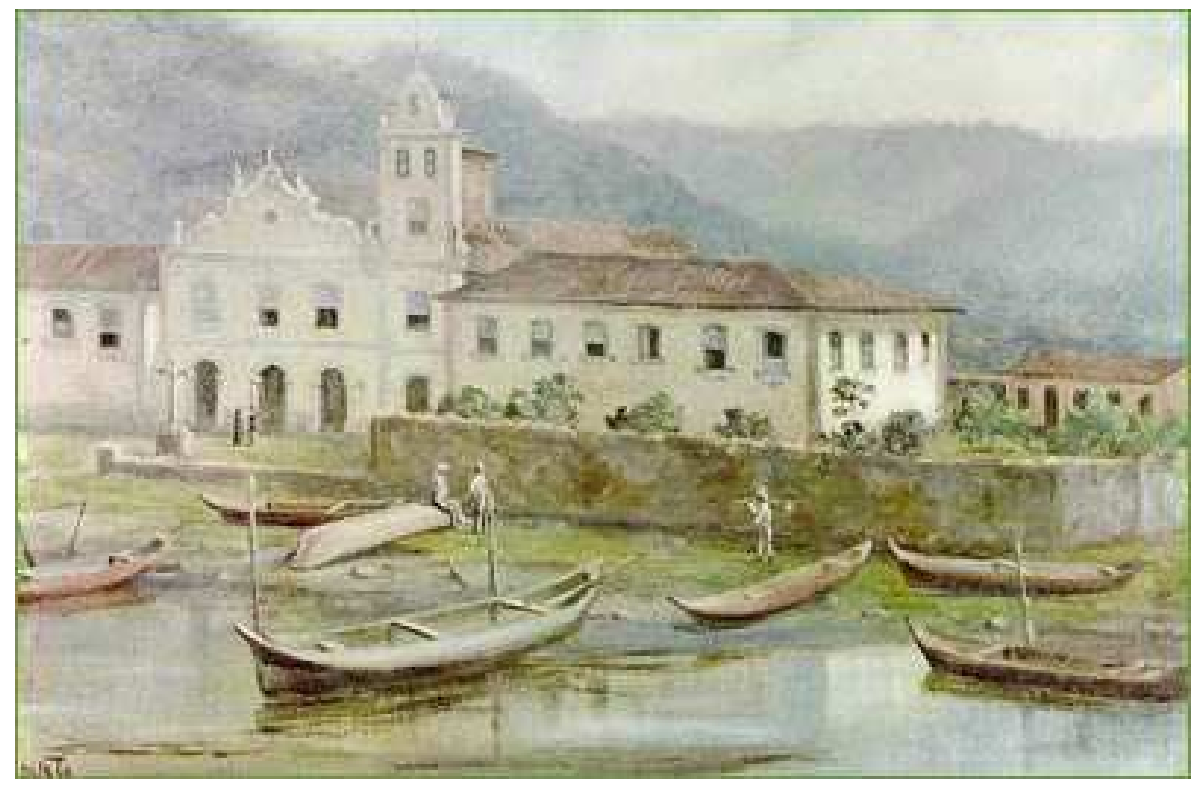

Figura 16: Igreja e o Convento do Valongo com o chamado Porto das Canoas, em 1840, por Benedito Calixto. (Fonte: PRODESAN - Progresso e Desenvolvimento de Santos S.A.. Benedito Calixto: reprodução de seis telas do grande pintor. Santos: Ed. Prodesan Gráfica, 1978.)

Assim, o grupo liderado por Cândido Graffrée e Eduardo Guinle ${ }^{22}$ foi autorizado a construir e explorar o porto de Santos por 39 anos, ampliados por mais 90 anos em 1890 pelo governo republicano. As obras começaram imediatamente, encontrando resistência e gerando tensões entre os trapicheiros - e os donos de armazém, e a Cia Docas pelo controle do processo de embarque e desembarque de mercadorias. Gitahy (1992) explica que os comerciantes não queriam que uma única empresa ditasse as taxas a serem pagas para o embarque e desembarque de mercadorias. Na realidade, esse tipo de monopólio comercial não estava estipulado

\footnotetext{
${ }^{21}$ GUINLE, Eduardo Palassim, op. cit.

22 Transformados na empresa Gaffrée, Guinle \& Cia., com sede no Rio de Janeiro, mais tarde mudando para Empresa de Melhoramentos do Porto de Santos e, em seguida, Cia. Docas de Santos.
} 
no contrato de concessão da Companhia Docas. No entanto, o governo apoiava a retirada dos trapiches alegando irregularidades na arrecadação dos impostos alfandegários sobre mercadorias que transitavam por eles. Os dois últimos trapiches, Ferreira Gullart e Xavier Pinheiro, tiveram suas pontes demolidas em outubro de 1897. O fim dos trapiches significou a derrota das elites locais perante o grande capital.

Em 1892, um ano após a data prevista no contrato, foram inaugurados os primeiros 260 metros do cais ${ }^{23}$, localizados da altura da Rua Brás Cubas até o Valongo, na ponte da São Paulo Railway. Ainda no mesmo ano, sete meses mais tarde, foi entregue o primeiro armazém e, em 1893, foram construídos mais 400 metros de cais.

A reforma e ampliação do porto representaram uma solução para a consolidação da economia cafeeira do Estado de São Paulo. Contudo, o problema das epidemias que assolavam a cidade passou a atingir a capital e o interior do estado levadas, principalmente, pelos imigrantes que desembarcavam em Santos rumo às fazendas de café. Em 1892, a cidade foi alertada pelo presidente do estado sobre a necessidade de se adotarem medidas de saneamento devido aos entraves que as epidemias poderiam impor ao desenvolvimento da economia cafeeira, ameaçando a comunicação com o exterior, haja vista a condição santista de porta para o mar.

Dessa maneira, compreende-se que a reforma portuária e a adoção de medidas sanitárias em Santos não podem ser desvinculadas, já que faziam parte de um mesmo programa do governo federal e estadual para melhorias das

${ }^{23}$ Com 20 metros de largura para depósito das mercadorias durante as atividades de embarque e desembarque. 
exportações, muito embora não constituíssem o mesmo projeto. Como demonstram os relatórios estaduais da Secretaria de Agricultura, Comércio e Obras Públicas do Estado de São Paulo, a partir de 1892 havia uma intensa atividade no setor de obras públicas e intervenções urbanas, estando o desenvolvimento urbano na posição de meta do governo paulista durante o regime político republicano (BERNARDINI, 2006).

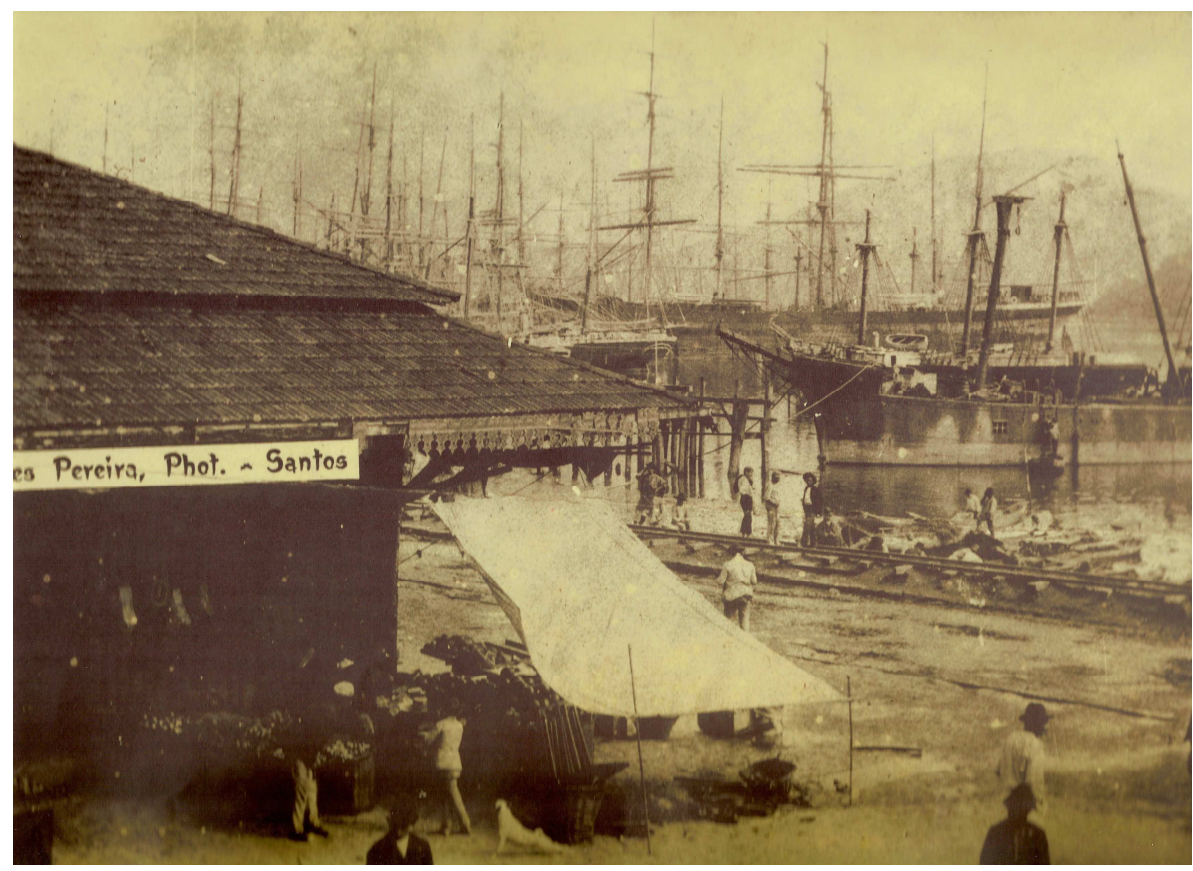

Figura 17: Construção do cais em 1890. Foto de José Marques Pereira. (Acervo Gino Caldatto Barbosa / fonte: CALDATTO, Gino. Santos e seus Arrabaldes - Álbum de Militão Augusto de Azevedo. São Paulo: ed. Magma Editora Cultural, 2004)

\section{I.9. As reformas urbanas em Santos.}

Na virada do século XIX para o XX, São Paulo e Santos viveram mudanças significativas nas suas estruturas urbanas, fruto da reordenação sócioeconômica consolidada nesse período. Nesse sentido, Bernardini (2006) afirma que as intervenções nas duas cidades explicam-se mais pelo papel desempenhado na economia paulista frente ao capitalismo mundial e por suas particularidades históricas e geográficas do que por um modelo de cidade pré-determinado. 
No caso de Santos, os problemas sanitários que dizimavam centenas de pessoas no final do século XIX, influenciavam diretamente a economia do estado. Ao mesmo tempo em que o café se expandia necessitando de mais mãode-obra, as epidemias em Santos eram agravadas com o aumento de imigrantes que permaneciam na cidade por alguns dias antes de se dirigirem às fazendas de destino. Além disso, havia outro montante de trabalhadores que vinham a Santos em busca de oportunidades de emprego e viam-se condicionados a se instalar em cômodos ou cortiços, uma vez que as moradias existentes não eram suficientes para abrigar toda a massa imigrante e, além do mais, as casas disponíveis tinham preços inacessíveis. Soma-se a eles, o segmento dos recém-libertos que foram expulsos das terras dos antigos quilombos, após serem valorizadas pelo progresso urbano da cidade.

\begin{abstract}
"Adequar a cidade a essas novas demandas não foi tarefa fácil, pois implicava no aumento do número de carroças nas ruas para o transporte das mercadorias, e de cocheiras que servissem para abrigo das carroças. Estas atividades chamam a atenção das autoridades sanitárias para o número de epidemias e trabalhadores imigrantes que estes serviços requerem. Não há uma política de moradia para os trabalhadores, aliás, como não há nenhuma política que assegure qualidade de vida; portanto, a oferta de moradia e emprego não condiz com o aumento das necessidades de mão-de-obra e serviços." (BLUME, 1998, p. 20)
\end{abstract}

Portanto, a organização do porto interferiu diretamente na adoção de medidas sanitárias que deveriam dotar a cidade de espaços amplos e desobstruídos por onde pudessem circular o transporte feito por carroças e os bondes puxados por muares. Nada de vielas e estruturas coloniais, a construção de largas avenidas, praças e passeios denotavam uma nova dinâmica social.

A adoção de medidas sanitárias era uma necessidade urgente. A Cia Docas havia se comprometido em colaborar com o saneamento da cidade, até 
porque, como se viu, a construção do porto e o saneamento de Santos eram obras interligadas. Às Docas coube a dragagem do lodo negro que circundava a cidade e o aterro de uma grande extensão à beira-mar, onde estavam inclusas algumas ruelas, além da canalização de riachos existentes nessa região.

Igualmente, o governo do estado passou a intervir nas políticas de saneamento de Santos sob a forma de comissões. A Comissão de Saneamento do Estado, criada em abril de 1892, estava ligada à Secretaria de Agricultura, Comércio e Obras Públicas e visava sanear as cidades através de obras de canalização de água e construção da rede de esgotos. Era também responsável pela construção do Hospital de Isolamento e da Hospedaria dos Imigrantes. Já a Comissão Sanitária, vinculada à Secretaria dos Negócios do Interior, exercia o poder de polícia sanitária, ou seja, era responsável por vistoriar as habitações, fiscalizar a limpeza dos quintais e terrenos baldios, além de promover desinfecções e a vacinação (BERNARDINI, 2006; GITAHY, 1992; LANNA, 1996).

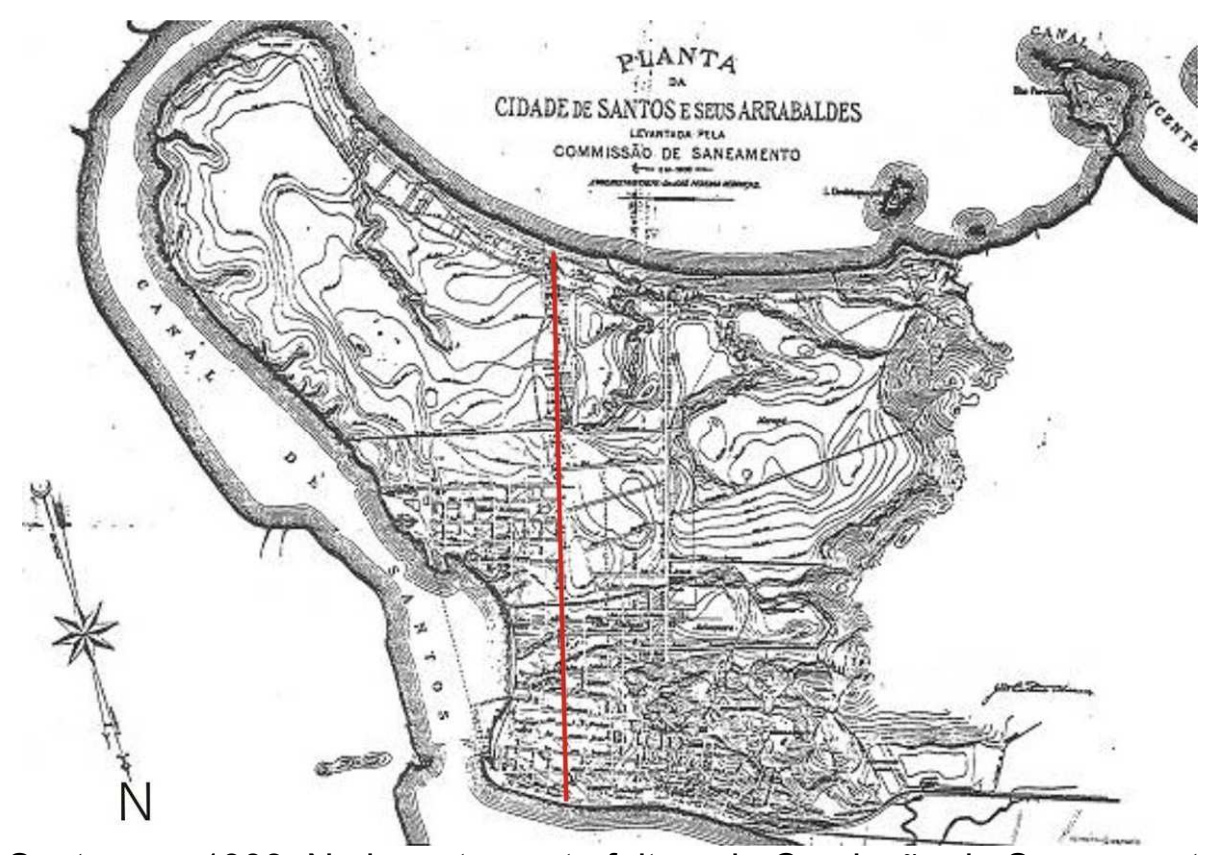

Figura 18: Santos em 1903. No levantamento feito pela Comissão de Saneamento já se vê a Avenida Conselheiro Nébias (marcada em vermelho). (Fonte: Site Novo Milênio - disponível em: www.novomilenio.inf.br/santos/mapa31g.htm. Acesso em: janeiro de 2007) 
Os serviços de abastecimento de água em Santos foram iniciados a partir da instalação de um sistema de encanamentos no centro da cidade, que se utilizava de rios próximos e nascentes nos morros. A primeira a fornecer o serviço de canalização de água e iluminação pública a gás foi a Companhia Melhoramentos de Santos, substituída posteriormente pela Companhia City of Santos Improvemens Co. Ltd..

Em 1870, Domingos Moutinho adquiriu concessão por 50 anos para explorar os serviços de transporte por bondes a tração animal, fundando a Companhia Melhoramentos de Santos. Em 1871, se juntaram ao fundador da companhia mais três capitalistas: major J. Frederico Russel, Thomas Cochrane e o engenheiro Everett Benest. Em 1881, a companhia foi comprada pela Cia City, formada por capital inglês, que passou a prestar os serviços de água, iluminação a gás e transporte. Assim, a concessão do abastecimento de água foi um dos primeiros passos para a modernização de Santos, uma vez que, até então, a cidade não possuía um sistema de distribuição de água, tendo que se submeter a comprála de vendedores ambulantes que a buscavam em algumas fontes e bicas distantes e a transportavam em pipas sobre carros de boi (BERNARDINI, 2006).

Além dessas medidas, o governo estadual convidou o Engenheiro Estevan Antonio Fuertes ${ }^{24}$ para realizar o plano de saneamento de Santos. Furtes promoveu uma série de levantamentos com a colaboração da Comissão de Saneamento, então chefiada pelo engenheiro João Pereira Ferraz. Os relatórios parciais de Fuertes traziam recomendações a serem adotadas através de medidas

\footnotetext{
${ }^{24}$ Furtes nasceu em Porto Rico e foi professor de engenharia sanitária na Universidade de Cornell (EUA). Segundo BERNARDINI (2006, P. 87), "graduou-se pelo Instituto Politécnico Rensselear, recebendo o grau de bacharel em filosofia, doutor em medicina e em engenharia civil, além de muitos diplomas e prêmios."
} 
localizadas que visavam evitar que as condições sanitárias de Santos piorassem. Os relatórios recomendavam a proibição de depósitos de lixo na área da cidade e a construção de um novo cemitério, o "Cemitério da Conceiçãozinha", cujas obras não tiveram continuidade. A Comissão, sob a tutela de Fuertes, também estava envolvida com as obras de drenagem na Avenida Conselheiro Nébias, cuja zona intermediária entre a Barra e a região central era constituída de alagadiços.

Percebe-se a intenção do governo estadual de participar nas decisões da municipalidade, o que, na grande maioria das vezes, resultou em embates e crises entre os dois governos, municipal e estadual. A atitude da chefia do estado deve ser entendida no contexto do projeto republicano paulista que visava desenvolver e expandir os investimentos através da autonomia estatal mantendo o domínio dos representantes do grande capital cafeeiro sobre a lavoura:

"Hinterland' é entendido como território cuja unidade é mais sócio-política do que natural, pois é dada pela mobilização e drenagem de seus recursos por um núcleo urbano polarizador, através de iniciativas e controles adotados por uma classe dominante local e sua elite dirigente, atuando através do Estado." (SZMRECSANYI, 1993, p. 206)

A atuação do Estado como forma de consolidação da hegemonia dos cafeicultores paulistas também pode ser notada no Rio de Janeiro através da reforma do porto atrelada às intervenções de cunho sanitarista na cidade, por Pereira Passos. A remodelação urbana estava intimamente ligada à imagem de governo sólido e economia estável que se procurava transmitir, como demonstra Sevcenko (1984) no episódio da Revolta da Vacina.

Contudo, as reformas não aconteceram apenas em função de uma imagem modernizadora ou de prover melhores condições de salubridade aos habitantes da cidade. O crescimento populacional provocava não só o aumento da 
mortalidade causado pelas péssimas condições de moradia e pelo avanço das epidemias, mas também colocava frente a frente segmentos sociais distintos. Nesse sentido, o sanitarismo funcionava para além das suas atribuições iniciais, pois representava uma forma de controle social.

"Na inexpressividade das antigas cidades coloniais, senhores, escravos e pobres livres compartilhavam o mesmo diminuto espaço. Separava-os já uma evidente desigualdade perante a lei. Com o crescimento no início da República, contudo, consolidado o regime de trabalho livre, os bairros burgueses e operários foram se destacando. Ganhavam contornos próprios, apartando pessoas que, juridicamente iguais, se distanciavam apenas pela posição de classe." (GAMBETA, 1984, p. 17)

Em Santos, embora o plano de Fuertes não tenha sido realizado integralmente ${ }^{25}$, outras duas comissões foram eleitas depois dele com o mesmo propósito de organizar a cidade: a de Thomas Cochrane em 1896 e a de Alfredo Lisboa em 1897, que tentaram em vão solucionar o problema dos esgotos. Em 1897, também foi estabelecido o Código de Posturas Santista vinculado ao Código Sanitário do Estado, reforçando o poder de polícia instituído à Comissão Sanitária (ANDRADE, 1991; BERNARDINI, 2006).

Em 1905, o engenheiro Saturnino de Brito assume a Comissão de Saneamento e dá início às obras do sistema de esgoto proposto por Fuertes que estava baseado na separação absoluta entre águas cloacais e águas pluviais. A esse sistema foram incorporadas algumas modificações propostas por Saturnino, como as estações elevatórias distritais. Enfim, entre 1905 e 1914 foram executados os $80 \mathrm{~km}$ de rede de esgoto e mais $17 \mathrm{~km}$ de canais de superfície para águas pluviais, além da inauguração, em 1906, das obras do emissário de esgotos, com 12 $\mathrm{km}$.

${ }^{25} \mathrm{O}$ resultado dos estudos de Fuertes foi publicado em 1894 e 1895 e suas propostas serviram de base para sugestões posteriores acerca do saneamento de Santos. 
O plano apresentado por Saturnino à Câmara em 1910 foi parcialmente executado e se apoiava nas idéias de Camilo Sitte, incorporando ao plano as ruas já existentes e considerando a cidade como totalidade. Além disso, essa proposta pretendia responder ao problema do crescimento urbano a médio e longo prazo, incorporando a isso a questão social para que toda a população pudesse ser beneficiada pelos melhoramentos (LANNA, 1996).

"Sem dúvida, com o plano de saneamento, melhoramentos e extensão que Saturnino de Brito elabora e implanta em Santos, mesmo não tendo sido realizado em todos os seus aspectos, não apenas temos a construção de uma cidade moderna, mas também a aplicação de princípios urbanísticos revolucionários para a época, onde o passado colonial da cidade desaparece em nome de um futuro marcado pela higiene e progresso, que influenciará decisivamente o desenvolvimento do planejamento urbano no Brasil." (ANDRADE, 1991, p. 63)

O ideal de embelezamento aparece vinculado às intervenções higienistas nesse período. A imagem da cidade de traços coloniais dá lugar a novas formas urbanas subordinadas a uma ordem que demonstra o domínio da natureza pelo homem. A partir das orientações de Saturnino, o lote estabelece uma nova relação com o edifício, isolando a moradia para promover a ventilação e insolação. Com a mesma finalidade higienista, houve o alargamento das avenidas e ruas para a condução e renovação de oxigênio. A nova estrutura urbana se diferenciava radicalmente da colonial, imprimindo novos padrões estéticos sem perder a harmonia do conjunto, ou seja, buscava-se "o contato poético com uma paisagem sob controle - natureza submissa - mas que não perde a beleza dos organismos em harmonia” (ANDRADE, 1991, p. 61). 


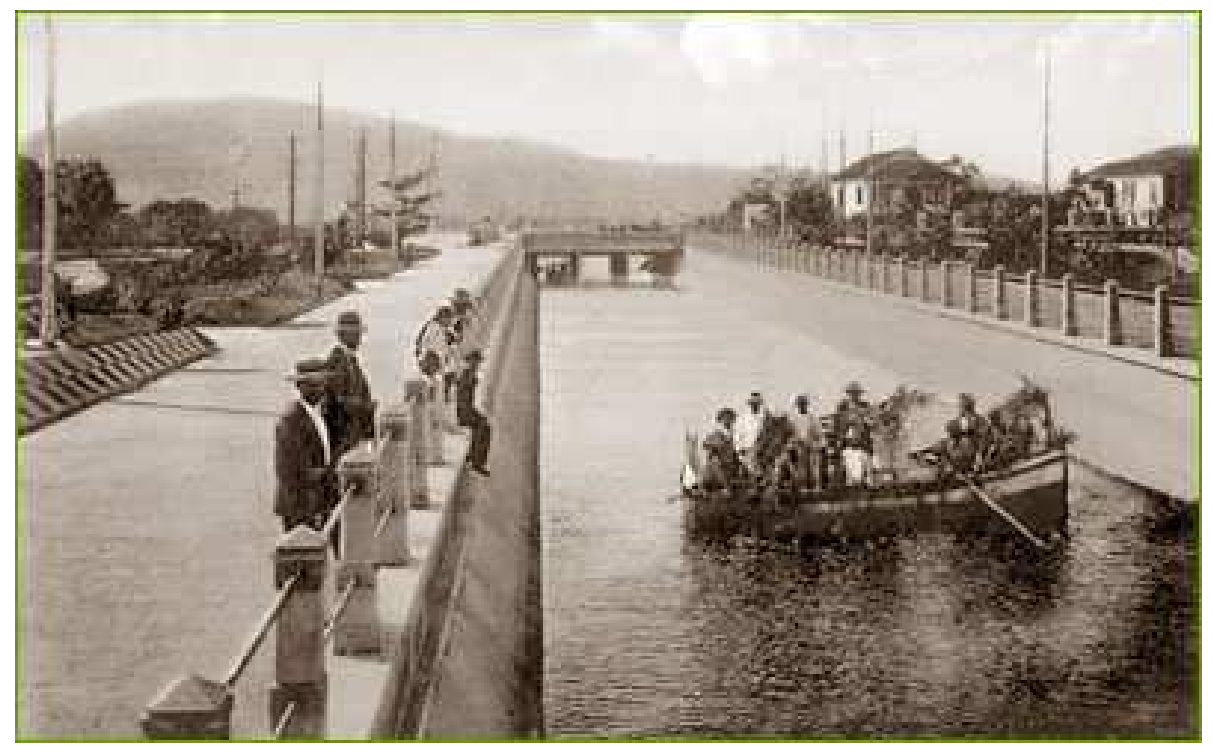

Figura 19: O Canal 1 no ano de sua inauguração.

(Coleção João Gerodetti / Fonte: Prefeitura Municipal de Santos)

$\mathrm{Na}$ verdade, o ideal de embelezamento já era pauta corrente em

Santos desde as primeiras décadas do século XIX, como se poder ver com a implementação, em 1839, do primeiro Código de Posturas proposto pela Câmara e aprovado pela Assembléia Legislativa Provincial em 07 de março de 1847. O código já estabelecia nessa época exigências quanto à largura das vias, ao alinhamento e à configuração das fachadas - estabelecendo inclusive regras de proporção e simetria entre portas e janelas, tamanho de beiral e estilo arquitetônico, como se vê no trecho do artigo $3^{\circ}$., transcrito a seguir. Além disso, o código instituía a figura do "Arruador", a quem competia aplicar as normativas do código quando fosse determinado pela Câmara (NUNES, 2001).

"As portas terão treze palmos de altura, e de cinco a seis de largura não compreendendo a grossura das ombreiras; as de coxeira terão quatorze palmos de altura, e serão sempre mais largas que as outros pelo menos hum palmo. Estas portas deverão em todo caso guardar symetria com as outras portas e janellas do Edifício. As janellas de peitoril nas cazas térreas terão sete palmos de altura, e nos sobrados 8 1/2 palmos; as de sacada terão treze palmos de altura, e umas e outras terão de largura cinco a seis palmos, não compreendendo a grossura das ombreiras. Nos sobrados as janellas do $3^{\circ}$. Pavimento (e dahi para cima em todos os mais) decrescerão sempre meio palmo em cada pavimento. As faces superiores das soleiras das janellas de peitoril ficarão sempre cinco palmos acima do soalho do Edifício nas casas de sobrado, e cinco e meio palmos acima do nível das 
soleiras das portas nas casas térreas. As portadas e vergas das janellas como das portas terão pelo menos seis polegadas de largura na face da rua. Os claros que ficarem entre as portas e janellas deverão ser proporcionados a largura que tiverem as frentes, e serão iguaes em cada um edifício." 26

No final do século, entretanto, essa perspectiva de embelezamento vinha acompanhada por uma política repressora e destruidora de outras formas de vida que não condiziam com o ideal almejado. A Comissão Sanitária, através do poder de polícia instituído pelo Estado, agia sobre a cidade e seus habitantes, exterminando os cortiços pela demolição a força e desalojando centenas de moradores numa batalha desigual, na qual a população local era culpada pelas mazelas e vícios da cidade. Essas ações foram fortalecidas pela instituição do Código Sanitário e pelo novo Código de Posturas Santista de 1897, instrumentos que permitiam a violação domiciliar em prol da saúde coletiva (LANNA, 1996; GAMBETA, 1984).

Os estudos de Fuertes demonstravam que, em 1893, Santos já teria cerca de 30.000 habitantes alojados em 3.234 casas, casebres e cortiços (GITAHY, 1992). Em 1894, os cortiços foram regulamentados através da Lei $n^{\circ} .46$ de 17 de outubro, proibindo sua construção e obrigando os proprietários a torná-los higiênicos. Já a Lei 58 de 03 de novembro de 1894 autorizava a construção de vilas operárias em Santos (NUNES, 2001). A população desalojada acabava atirada à rua, procurando novas acomodações e novos lugares dentro da cidade. Gambeta (1984) afirma que as vilas operárias e os familistérios prometidos desde o surto de 1889 nunca chegaram a ser construídos nem pelo Estado, nem pela municipalidade.

\footnotetext{
${ }^{26}$ Código de Posturas Santista de 1847, transcrição paleográfica feita por Sônia Maria Fonseca,
} citada por NUNES (2001, p. 28). 


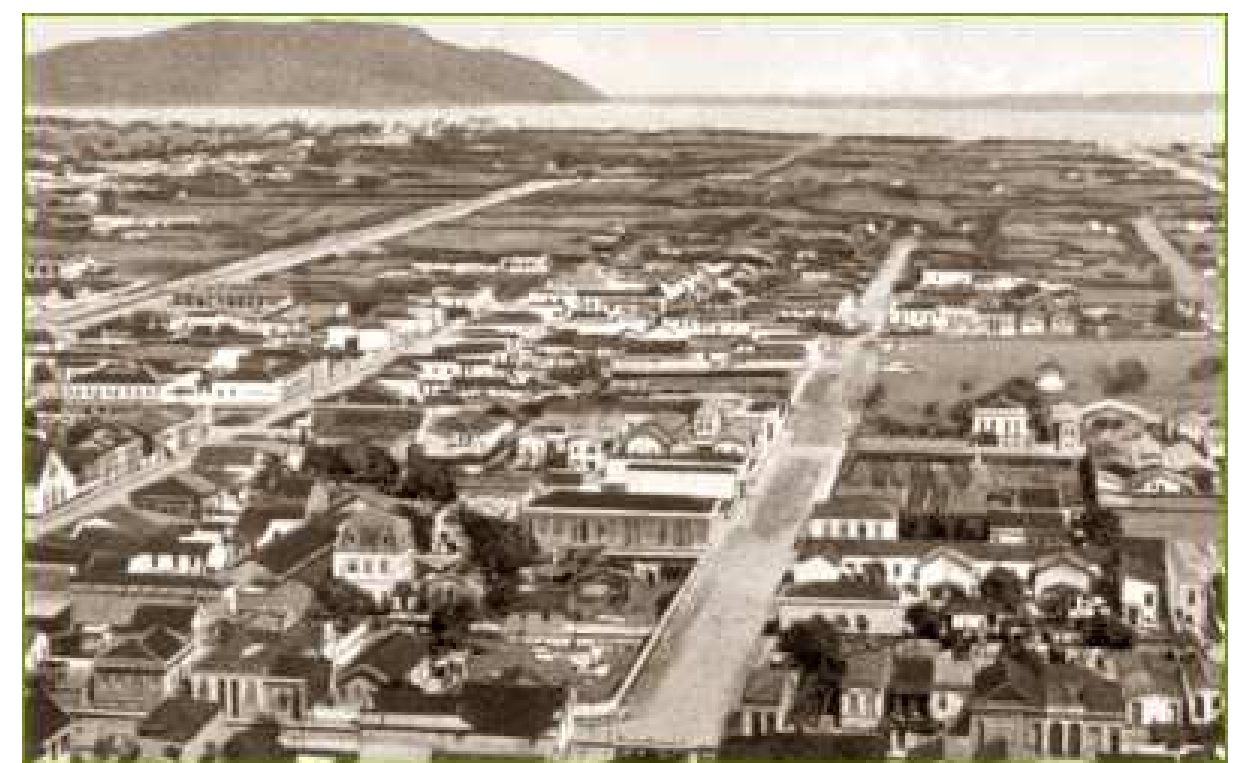

Figura 20: Vista de Santos a partir do Monte Serrat, em 1915. Ao centro, vê-se a Avenida Ana Costa; mais a esquerda está a Conselheiro Nébias e ao fundo a praia.

(Fonte: Prefeitura Municipal de Santos)

A partir de 1896, o processo de extermínio dos cortiços foi intensificado e a população passou a construir seus barracos nos arrabaldes da cidade, ocupando morros como o do Fontana - local do antigo quilombo do Jabaquara, e bairros ainda não urbanizados como a Vila Mathias e o Macuco. Por "coincidência", nesse mesmo ano, em 12 de agosto, foi instituída a Lei 82, que estabelecia novos parâmetros de ordem estética e higiênica a serem seguidos, para que ao longo das avenidas Ana Costa e Conselheiro Nébias - que ligavam o centro à praia, surgisse uma nova e moderna cidade (NUNES, 2001).

"Os morros ofereciam duas vantagens aos trabalhadores: ficavam mais perto da área portuária e o aluguel dos terrenos era mais baixo. Por outro lado, o suprimento de água era precário ou inexistente e, especialmente nos dias de chuva, o acesso pelas ladeiras íngremes, lamacentas era quase impossível. Os morros começaram a ser ocupados, na virada do século, primeiramente pelos portugueses e ilhéus, talvez já acostumados em sua terra de origem a viver em encostas, junto ao mar. Construíram os característicos chalés de madeira, também encontrados em Vila Macuco e Vila Mathias para onde outros imigrantes também mudaram". (GITAHY, 1992, p. 130)

A população tentou reagir a esse processo como pôde, resistindo a todo tipo de intervenção sobre seus modos de viver, o que não resultou em sucesso. 
Foram empurrados para os morros e a periferia definindo, assim, seu lugar segregado da cidade que se formava. Como afirma Gambeta (2001, p. 25), "o mesmo processo que introduzia melhoramentos públicos, elegia os excluídos desses benefícios". 
CAPÍTULO II

Memória e identidade urbana: discussão conceitual

"Uma casa tem muita vez as suas relíquias, lembranças de um dia ou de outro, da tristeza que passou, da felicidade que se perdeu. Supõe que o dono pense em as arejar e expor para teu e meu desenfado.

Nem todas serão interessantes, não raras serão aborrecidas, mas, se o dono tiver cuidado, pode extrair uma dúzia delas que mereçam sair cá fora."

(MACHADO DE ASSIS, Relíquias de casa velha) 


\section{II.1. Introdução.}

Este capítulo aborda a memória como um dos elementos fundamentais da condição humana. Falar de memória é falar do presente humano, pois ela é a responsável pela capacidade do homem de se situar no tempo e de pertencer a um espaço e, assim, à memória associam-se as formulações de identidades, individuais ou coletivas.

A memória se refere ao passado, mas é constantemente reformulada pelos indivíduos no presente de acordo com os subsídios de que dispõem. É, portanto, trabalho e está atrelada à mudança, pois a memória é fluida, é construção social e, apesar de sua fluidez que implica na impossibilidade de cristalizá-la, necessita de suportes físicos para ser evocada.

Entender de que maneira tais suportes se tornam referências fundamentais para as práticas sociais e para a afirmação de identidades, assim como analisar de que modo eles adquirem identidades no contexto urbano ao responderem as necessidades dos indivíduos no tempo histórico são preocupações deste capítulo. Derivada dessas questões está a discussão acerca da necessidade de se preservar essas estruturas como chaves de acesso à memória, analisando através da história os conflitos e os interesses envolvidos nesse processo. 


\section{II.2. Memória e a formação da identidade nos indivíduos.}

Viver na cidade significa estar em contato cotidiano com o diferente, com o outro, mesmo que o outro esteja cristalizado em estruturas físicas inanimadas. Através da sua disposição no espaço, do modo como estão ordenadas ou da sua configuração, tais estruturas nos remetem a hábitos e costumes de alguns grupos aos quais podemos ou não estar vinculados. É dessa relação com a alteridade pelo contato direto ou mediado que afirmamos diariamente nossa individualidade.

Ainda que os homens construam individualmente imagens a respeito de práticas sociais e criem seus referenciais a partir de suas lembranças, necessitam de recorrer a pontos de referência fora de si para evocá-las, como defende o sociólogo Halbwachs (2006) ao discorrer sobre a memória individual. Segundo o autor, a participação do grupo social e da memória coletiva na reconstrução de lembranças é imprescindível, o que faz da memória um fenômeno social $^{27}$.

O indivíduo, no entanto, não deixa de ser determinante para o pensamento social. Cada homem tem um fluxo de impressões inteiramente pessoais dos fatos sociais, ou seja, cada memória individual tem um ponto de vista da memória coletiva e essa subjetividade é relacionada ao lugar social ocupado pelo indivíduo, que também varia em função das relações tecidas em outros meios.

"As lembranças coletivas viriam se aplicar sobre as lembranças individuais e assim poderíamos agarrá-las mais cômoda e mais seguramente; mas

\footnotetext{
${ }^{27}$ Segundo Barros (1989), Halbwachs era adepto do pensamento da escola sociológica francesa durkheimiana, que via o homem como produto do meio social. Por isso, foi um dos primeiros autores a inserir a presença do social nas discussões sobre memória, que então era tratada a partir de visões introspectivas.
} 
para isso será preciso que as lembranças individuais já estejam ali - senão a nossa memória funcionaria no vazio. (...) Tudo isso parece demonstrar que em todo ato de memória haja um elemento específico, que é a própria existência de uma consciência individual capaz de se bastar." (HALBWACHS, 2006, p. 80)

Nessas relações, os objetos participam como uma espécie de sociedade silenciosa garantindo a formação de um quadro de referências que se adaptam às nossas percepções do presente e apóiam nossa permanência na cidade.

Torna-se fundamental sublinhar que esses objetos, em si, contêm apenas características materiais e que os valores e os papéis que assumem nas relações sociais são atribuições humanas e não uma propriedade intrínseca às coisas. É certo que os traços materiais dos objetos - como a matéria prima de que são constituídos, as técnicas de sua produção, sua forma, usos e sinais que indiquem suas condições operacionais, formam um conjunto de dados que permitem conclusões acerca da organização socioeconômica dos indivíduos envolvidos na existência desses objetos. No entanto, o sentido das coisas deve ser buscado fora delas, mesmo que sua materialidade permita tais raciocínios (MENESES, 1998). E, se tal produção e consumo de sentido são processos mediados pelo homem, logo são historicamente marcados.

Dessa forma, a memória, como atributo que situa o homem no tempo conferindo-lhe a percepção de sua finitude, necessita dessas estruturas materiais que estão estreitamente ligadas à manutenção da nossa capacidade de lembrar para a formação e manutenção de identidades.

Inicialmente, a identidade pode ser definida como aquilo que diferencia um indivíduo social dos outros, aquilo que garante peculiaridades às 
biografias e, ainda, uma compreensão global pelo indivíduo do lugar que ocupa na sociedade. Esse processo de afirmação de si acontece diariamente, no momento mesmo em que entramos em contato com o outro e confrontamos estruturas psíquicas, ideológicas ou estéticas à memória daquilo que afirmamos ser.

"Memória é, assim, uma forma de ação, uma ação representativa, parte da atividade auto-representativa que uma sociedade, grupo ou indivíduo produzem de si, para assumirem e defenderem sua identidade e para orientarem sua ação individual ou coletiva." (GUARINELLO, 1995, p. 188)

A perda da memória estaria, portanto, associada à perda da identidade. Este fenômeno aparece como uma das grandes ameaças do mundo moderno: o trabalho passa a ser constituído por atos mecânicos e repetitivos para os quais o aprendizado da vida perde o sentido. Além disso, o surgimento da escrita e o fim da tradição oral, o imediatismo do presente, a individualização, entre outros fatores apontam para a perda da transmissão de valores e conhecimentos entre gerações (BOSI, 1994; SANTOS, 2003). Como contraponto a isso, aparece o discurso sobre uma força inovadora presente nos indivíduos, que justificaria a ideologia da tábula rasa.

Dentro da perspectiva de que a memória seria constituída a partir de vínculos sociais, Hannah Arendt (1992) afirma que indivíduos modernos vivem em uma "felicidade limitada" na medida em que perdem não só a memória como a capacidade de reflexão sobre essa perda. Uma vez que os próprios indivíduos são constituídos por desejos, anseios e comportamentos que não estão encerrados em si mesmos, mas em práticas coletivas, a apreensão de um estado de felicidade plena se torna inalcançável sem a referência da memória; "somente em raríssimas ocasiões a mente humana é capaz de reter algo inteiramente desconexo" (ARENDT, 1992, p. 31). 
Ainda a respeito da importância do passado para a compreensão do presente, Meneses (1992) descreve o caso de uma pesquisa realizada por Endel Tulving $^{28}$ sobre o jovem conhecido na literatura médica como K.C. que após um trauma cerebral teve perda de reminiscências pessoais (memória episódica) mantendo apenas as lembranças impessoais (memória semântica). Segundo Tulving, o paciente era incapaz de se lembrar de experiências pessoais ocorridas antes ou depois do acidente, entretanto, era capaz de descrever fatos ocorridos com ele no passado, mas não se reconhecia como o sujeito das ações, ou seja, descrevia os acontecimentos como se fosse um observador externo sem uma compreensão subjetiva do tempo experimentado.

Observa-se no caso descrito que a falta de resquícios de memória neutraliza a identidade, ou seja, sem o referencial do passado o presente fica incompreensível e a projeção de futuro é impossibilitada.

Essa vinculação fundamental entre memória e identidade, onde a memória aparece como elemento-chave para a condição humana também é temática explorada na ficção, como nos filmes "O Caçador de Andróides" (Blade Runner), "Amnésia” (Memento) e em tantos outros.

O primeiro ${ }^{29}$, dirigido por Ridley Scott, se passa no ano de 2019 e narra a luta de andróides (criaturas geradas para servirem como soldados) para

\footnotetext{
${ }^{28}$ Neurocientista canadense, professor da Universidade de Toronto e Washington University, descreveu três tipos de memórias: episódica, semântica e processual ou procedimental. Segundo Lopes (2003), a primeira está restrita a um contexto têmporo-espacial e diz respeito a hábitos cotidianos. A segunda é a memória de fatos, conceitos e significados e a terceira delas não se pode examinar de modo consciente, pois requer execução de condutas específicas para ser apreendida. Os três tipos de memórias estão contidos dentro da memória declarativa ou explícita que se expressa mediante um sistema simbólico.

${ }^{29}$ O roteiro do filme foi escrito por Hampton Fancher e David Peoples, baseado na novela Do Androids Dream of Electric Sheep?, ficção científica de Philip K. Dick escrita em 1968.
} 
sobreviver além dos quatro anos programados de vida adulta. Como os andróides não têm memória, a identidade é construída a partir de implantes de fragmentos de memória humana associados a objetos que remetessem a uma história familiar no passado como fotografias espalhadas pela casa, por exemplo. As lembranças são usadas como provas para encobrir a condição de andróide das personagens, ou seja, para se identificarem como humanos é necessário que elaborem no presente um passado, mesmo que falso.

Em "Amnésia" converter memória de curto prazo em memória de longo prazo depois de sofrer um ferimento na cabeça quando tentava salvar sua esposa de um ataque. Após esse evento, Leonard é incapaz de se lembrar de fatos, de pessoas que encontra ou de suas ações no presente, ou seja, suas experiências recentes não constituem uma memória duradoura e desaparecem alguns minutos após terem acontecido. Apesar de suas lembranças de antes do acidente não terem sido apagadas, a identidade da personagem no presente não é estável porque uma parte de sua história não foi registrada. Leonard não sabe há quanto tempo o acidente aconteceu, não se reconhece no presente e se torna joguete dos interesses de outras personagens da trama. Para encontrar o assassino de sua esposa Leonard fotografa, faz anotações em papel e tatua no próprio corpo pistas que acha importante. A falta de arquivamento de lembranças de um período da história desarticula a compreensão do tempo, desestabiliza a identidade e incapacita a ação consciente no presente, além de impedir projeções de futuro.

\footnotetext{
${ }^{30}$ Filme de 2001, com direção e roteiro de Christopher Nolan.
} 
A elaboração da memória se dá no presente, quando é reorganizada a partir de incentivos para responder às necessidades do seu tempo. Não pode ser relacionada a algo acabado, encerrado no passado, ou seja, a memória é fluida, maleável e está sujeita à dinâmica social. (BOSI, 1994; LE GOFF, 2003; MENESES, 1992).

Segundo Le Goff (2003), foi justamente esse caráter instável da memória que levou o surrealismo a questioná-la como produto da imaginação, frágil e enganadora, merecendo atenção especial de André Breton no Manifeste du Surréalisme, de 1924. Halbwachs (2006) se aproxima desse questionamento ao afirmar que a lembrança é uma imagem construída através dos materiais disponíveis no presente e a partir de nossa percepção atual - que varia com o tempo. Ao passado lembrado no presente estão associados pontos de vista, o que torna a memória relativa ao lugar temporal e espacial ocupado pelo indivíduo, ou seja, o "trabalho" 31 da memória é feito a partir de fragmentos de passado intercalados por fragmentos de presente.

"Tudo se passa como se o objeto fosse visto sob um ângulo diferente e iluminado de outra forma: a distribuição nova das sombras e da luz muda a tal ponto os valores das partes que, embora reconhecendo-as, não podemos dizer que elas tenham permanecido o que eram antes." (HALBWACHS apud BOSI, 1994, p. 57)

Em decorrência desse processo de reelaboração do passado na contemporaneidade, no momento em que um objeto antigo (ou uma construção antiga) é deslocado da sua função original para integrar acervo de museus, decoração ou ao se tornar monumento surge a possibilidade de que the sejam dados valores diversos daquele de uso que lhe fora atribuído na sua origem. Assim,

\footnotetext{
31 Alusão ao pensamento de Bosi (1994) que associa memória a trabalho justamente pela necessidade de reconstruir, repensar, refazer o passado com os referenciais do presente.
} 
as características para exercer a função original permanecem no objeto ou na construção antiga, no entanto, ao ser transformado em monumento seu valor de uso passa a ser apenas cognitivo, isto é, a função original passa a ser acessada apenas através da memória.

O espaço funciona, então, como uma espécie de arrimo para a memória. Objetos ou construções têm a propriedade de evocar lembranças que, no presente, contribuem para a construção da identidade nos indivíduos.

\section{II.3. Memória e Espaço: tipologia e identidade urbana.}

"Desorientados em relação aos pontos cardeais, privados do plano que fornece um argumento ao seu saber, os indígenas perdem rapidamente $o$ senso das tradições, como se seus sistemas social e religioso (veremos que são indissociáveis) fossem complicados demais para dispensar o esquema que o plano da aldeia tornava patente e cujos contornos os seus gestos cotidianos refrescavam perpetuamente." (LÉVI-STRAUSS, 1957, p. 231)

Nesse trecho de Tristes Trópicos, podemos notar não só a influência do espaço na afirmação da identidade, como também a necessidade constante do trabalho da memória em conjunto com o espaço para possibilitar tal afirmação. $\mathrm{O}$ conjunto de objetos que nos rodeiam, assim como o ambiente em que estão inseridos, funciona como elemento ativador desse processo no qual memória e identidade são reconstruídas e reafirmadas cotidianamente.

Há aqueles objetos que se destacam dos demais por representarem uma experiência vivida e, por isso, são guardados e incorporados à vida do possuidor como um ícone através do qual a memória acessa aquele fato marcante. Violette Morin (apud BOSI, 2004, p. 441) os denominou de objetos biográficos por 
guardarem as lembranças da vida do possuidor, por lhe serem caros ao ponto de envelhecerem ao lado dele, dando-Ihe a sensação de continuidade.

Esta conexão fundamental entre identidade e certos objetos e pessoas também é descrita por Celso Brito no poema "Encontro". A identidade é vista como construção social da memória - dinâmica e, por isso, sujeita a alterações nas suas reformulações no presente.

\section{"Encontro}

Procuro os que sabem de mim.

Os que disseram ter me ouvido falar.

Os que me encontram, quando me perco.

Em quantos poemas estou presente?

Em qual deles era verdade?

Perco-me um pouco todo dia, para me encontrar em tantos outros.

Não revelo, nem disfarço.

Apenas passo.

Mas há momentos em que me demoro." (BRITO, 2005)

Podemos transpor a relação entre objetos biográficos e seus possuidores ao patrimônio edificado. As construções nos contam uma parte importante das relações entre cidades e seus habitantes. A maneira de arranjá-las no espaço, os materiais e as técnicas empregadas na sua edificação ou mesmo os padrões estéticos utilizados para lhes dar forma e cor são elementos que corroboram para ativação da memória dos indivíduos que se relacionam naquele espaço.

As sociedades antigas se valiam da estabilidade espacial para garantir a manutenção da memória e, por conseqüência, a transmissão do conhecimento para as próximas gerações. A família, as relações de vizinhança, o 
apego a certos objetos e a maneira de arranjá-los espacialmente funcionavam como apoios da memória (BOSI, 2004; SANTOS, 2003).

Percebe-se que a adaptação do homem a determinado lugar é favorecida pela permanência da paisagem e pela imobilidade das pessoas. Segundo Halbwachs, essa apropriação do lugar acontece quando os pensamentos e os movimentos dos indivíduos se vinculam às imagens exteriores, ou seja, quando há a sedimentação dos hábitos dos indivíduos à materialidade que os cerca.

Portanto, as edificações participam da formação da identidade dos indivíduos no momento em que a memória é acionada - seja para garantir orientação espacial, fazer referência a outros lugares visitados ou simplesmente para reavivar lembranças de fatos pessoais ou provenientes da história pública que ocorreram naquele espaço garantindo a sensação de pertencimento a uma cultura e a um tempo histórico. E, do mesmo modo como ocorre aos objetos cujas formas perdem as arestas e se abrandam, moldando-se e ganhando expressividade através do manusear constante (BOSI, 2004), as edificações se tornam mais significativas para os indivíduos na medida em que são incorporadas ao cotidiano.

Assim, o que dizer das edificações antigas que vão sendo moldadas e adaptadas às novas maneiras de viver e às novas necessidades do homem no transcorrer do tempo? Tais construções se ainda sobrevivem na contemporaneidade é por estarem arraigadas na memória coletiva dos cidadãos tornando-se baluartes fundamentais de identidades, individuais ou coletivas.

"O território é essencialmente uma memória, e seu conteúdo é todo constituído de formas passadas - isto é, de algumas dentre elas, das quais só subsiste o que pode ser compreendido pela sociedade que, em cada época, trabalha em seus quadros" (LEPETIT, 2001, p. 149) 
As edificações que resistiram à passagem do tempo, ainda que tenham suas funções e formas originais alteradas, permitem à contemporaneidade constatar a permanência de alguns valores não só formais, embora a referência seja material, mas também ligados as práticas sociais dos envolvidos na sua produção e manutenção na cidade. Essas edificações são, então, testemunhos da permanência desses valores na história.

Entretanto, a construção da identidade dos indivíduos não deve ser associada a simples repetição ou manutenção de tradições, pois quando valores e conhecimentos transmitidos são reelaborados no presente se deparam com mudanças, diferenças e transformações que contribuem para a afirmação não só da identidade dos indivíduos, como do próprio tempo (GUARINELLO, 1995).

Nesse sentido, a condição humana também está representada no espaço habitado, na cidade enquanto história materializada, já que, como declarou Lewis Mumford (1944 apud ROSSI, 2001, p. 258), a cidade é o instrumento material de vida coletiva onde estão solidificados os conflitos e os consensos, ou seja, o pensamento toma forma na cidade, se materializa nas construções e numa infinidade de outras produções humanas. Contudo, ao mesmo tempo em que o pensamento é aplicado produzindo formas na cidade, essas formas igualmente condicionarão o pensamento. Delimitando espaços, criando recintos, propondo fluxos, planos, composições, as formas arquitetônicas e urbanas possibilitam a ação da razão na cidade, muito embora, destituída de sentido e de contexto, a forma pela forma perde tal capacidade de fixar o homem no espaço e no tempo (HALBWACHS, 2006; ROSSI, 2001). 
Assim, as impressões que temos dos lugares a partir de suas formas são possibilitadas pela memória, seja das experiências vividas naquele determinado espaço ou em outros espaços semelhantes aos quais também nos relacionamos de maneira afetiva. É justamente essa vinculação entre forma e memória que garante aos indivíduos a capacidade de caracterizar e atribuir qualidade ao espaço construído, ou seja, possibilita ao homem conferir identidades aos lugares.

As construções, assim como a cidade e toda a materialidade da qual é constituída, são produtos do trabalho humano - coisa humana por excelência, que se destinam a executar funções, mesmo que contemplativas. De acordo com as necessidades dos indivíduos a paisagem vai se adaptando e formas arquitetônicas são constituídas como respostas às aspirações estéticas e funcionais de cada sociedade. Vinculado à forma está o tipo que se apresenta como uma constante na arquitetura.

"A palavra 'tipo' não representa tanto a imagem de uma coisa a ser copiada ou imitada perfeitamente quanto a idéia de um elemento que deve ele mesmo servir de regra ao modelo (...) O modelo, entendido segundo a execução prática da arte, é um objeto que se deve repetir tal qual é; o tipo é, pelo contrário, um objeto segundo o qual qualquer pessoa pode conceber obras que não se assemelharão em nada entre si. Tudo é preciso e dado no modelo; tudo é mais ou menos vago no tipo. Assim vemos que a imitação dos tipos nada tem que o sentimento e o espírito não possam reconhecer (...)." (QUATREMĖRE DE QUINCY apud ROSSI, 2001, p. 25)

Entretanto, a respeito da origem dos tipos os autores Aldo Rossi (2001) e Giulio Carlo Argan (2001) apresentam argumentações que podem, inicialmente, parecerem antagônicas. Para Rossi, o tipo se apresenta como um ideal que precede e constitui o objeto arquitetônico, respondendo a necessidades formais e funcionais de uma sociedade em determinado momento histórico sendo, por 
conseguinte, um elemento cultural. O tipo é visto pelo autor como “a própria idéia da arquitetura, aquilo que está mais próximo da sua essência” (ROSSI, 2001, p. 27).

Argan argumenta que o tipo não é formulado a priori, mas sim deduzido de uma série de exemplares já existentes, ou seja, o tipo está submetido à existência prévia de uma série de edifícios que apresentam semelhança formal e funcional entre si. Contudo, a aparente contradição entre os posicionamentos dos autores acontece porque, na verdade, Argan se refere no texto ao tipo enquanto conceito teórico-arquitetônico, em outros termos: o tipo só se fixa enquanto conceito quando deduzido de uma série de edifícios existentes, porém Argan salienta que ele já existe anteriormente enquanto idéia, "numa determinada condição histórica da cultura, como resposta a um conjunto de exigências ideológicas, religiosas ou práticas” (ARGAN, 2001, p. 10).

Destarte, podemos entender o tipo como um esquema espacial envolvido em uma aura cultural e por isso, não obstante sua determinação prévia de características de necessidade, a forma é também influenciada pela técnica, função e momento histórico.

Percebe-se a vagueza que o conceito de tipo pode sugerir. Quatremère de Quincy (1832), citado pelos dois autores, ao discorrer sobre as mudanças formais que os objetos sofrem ao longo dos anos salienta a existência anterior fundamental de um princípio elementar do sentimento e da razão que, embora despido de suas características de forma, é conservado nas modificações do objeto.

"É como uma espécie de núcleo em torno do qual se aglomeraram e se coordenaram em seguida os desdobramentos e as variações de formas de que o objeto era suscetível. Por isso, chegaram até nós mil coisas de todo 
gênero, e uma das principais ocupações da ciência e da filosofia, para apreender as razões delas, é buscar-lhes a origem e a causa primitiva. É a isso que se deve chamar 'tipo' em arquitetura, como em todo outro ramo das invenções e das instituições humanas." (QUATREMĖRE DE QUINCY apud ROSSI, 2001, p.26)

Sob esse ponto de vista, nenhum tipo se identifica com uma forma, ainda que todas as formas sejam redutíveis a tipos e esse processo é, para Rossi, o postulado fundamental para o estudo da forma sem o qual seria impossível problematizá-la, uma vez que é uma ação lógica do pensamento. Ainda segundo o autor, a tipologia é o modelo analítico da arquitetura capaz de estudar os tipos arquitetônicos na complexidade do tema.

Ao pensarmos o tipo dentro desse processo de redução, não devemos entendê-lo como uma síntese estrutural determinante, mas como um princípio ou um esquema que possibilita infinitas variações formais. Argan acrescenta a isso a idéia de que os tipos podem sofrer mutações quando uma nova variante formal - solicitada para responder às exigências do seu momento histórico, for acrescentada à série formal anterior da qual o tipo havia sido deduzido, ou seja, a liberdade inventiva possibilitada pelo tipo promove modificações posteriores na sua própria estrutura.

Assim, a inventividade está subordinada a responder às necessidades do momento histórico da criação, superando as soluções sedimentadas transmitidas pelos tipos. Conclui-se, então, a partir dos dois autores supracitados, que a história exerce papel fundamental nos processos de criação e transformação do objeto arquitetônico e, por conseguinte, na construção de identidades urbanas. 
Não obstante a influência da história nas mutações sofridas pelos tipos, a permanência material das séries tipológicas na cidade são possíveis através de processos onde a memória é protagonista. Nas seleções, intencionais ou não, entre o preservar e o demolir, a memória é utilizada ideologicamente a fim de garantir a preservação de símbolos de necessidades ou aspirações de alguns grupos em determinado momento histórico.

\section{II.4. Memória e Poder.}

A memória coletiva pode, sem dúvida, ser vista como construção simbólica, na medida em que pode ser interpretada a partir de fatos representativos de grupos sociais que funcionam como seu suporte. Entretanto, para manter-se, precisa ser constantemente reanimada e, por isso, estruturas que promovam a vivência dessa memória são imprescindíveis para sua manutenção. Neste sentido, as edificações, assim como outras produções humanas, se tornam elementos simbólicos e sua preservação na cidade enquanto representação da sociedade pode estar vinculada a processos de inclusão ou exclusão social.

Várias memórias coletivas podem coexistir, mas a somatória delas não resulta na memória nacional ${ }^{32}$, que é da ordem da ideologia e que procura integrar e unificar os indivíduos através do escamoteamento de conflitos (MENEZES, 1992, p. 15). Nesse sentido, o Estado e as camadas dominantes geralmente se utilizam ideologicamente de suas memórias ou de memórias que lhe

\footnotetext{
${ }^{32}$ POLLAK (1989) afirma que, para a tradição européia do século XIX, a memória nacional era a forma mais completa de uma memória coletiva e esse pensamento, segundo o autor, está refletido no trabalho de Halbwachs, principalmente quando ele insinua um processo de negociação entre as memórias coletivas e individuais, segundo o qual indivíduos deveriam ceder em favor da adequação a uma base única.
} 
sejam favoráveis para formação e divulgação de uma memória dita nacional, suprimindo outras memórias coletivas.

"A memória coletiva é, deste modo, um meio fundamental da vida social, uma das dimensões da ação coletiva e um veículo de poder. Poder, por exemplo, de transmitir ou perenizar uma memória de si, ou de propor ou impor uma dada memória à coletividade; poder de criar, refazer ou destruir identidades sociais, de dar sentido, corpo e eficácia aos atos coletivos. $O$ ato da memória é um ato de poder e o campo da memória, o espaço onde atuam seus lugares, é um campo de conflitos." (GUARINELLO, 1995, p. 189)

Contudo, há no interior dessas reflexões duas características da memória que são imprescindíveis para a sua compreensão enquanto instrumento de poder: a memória é seletiva e, por conseguinte, é um fenômeno construído. O caráter seletivo da memória é certamente indispensável para a vida humana, já que seria impossível para qualquer indivíduo guardar todos os acontecimentos que lhe passassem durante a vida, do mesmo modo como teríamos o colapso de uma cidade que mantivesse todas as suas edificações desde sua origem. esquecimento, nesse sentido, se torna essencial para a vida tanto do homem quanto da cidade $^{33}$. Em decorrência da seletividade, alguns fatos são registrados e outros são esquecidos, ou seja, o que será preservado na memória dos indivíduos é escolhido em função de preocupações pessoais ou políticas pertinentes a determinado momento e, nesse sentido, a memória pode se tornar um instrumento de dominação, assim como o esquecimento (LE GOFF, 2003; POLLAK, 1989; POLLAK, 1992; SANTOS, 2003).

${ }^{33}$ Segundo SANTOS (2003), essa questão remete as reflexões de Nietzsche a respeito do eterno retorno que, para ele, seria a maior dificuldade a ser enfrentada pelo homem, já que a vida é absolutamente impossível sem o esquecimento - não no sentido de perda de memória, considerada irremediável, mas enquanto pré-requisito para a existência. Contrapondo a teoria de Milan Kundera, em $A$ Insustentável leveza do ser, para quem a vida humana se tornaria insuportável livre do peso do passado, Nietzsche defende que sem a lembrança o homem seria feliz. 
"A memória coletiva foi um importante elemento da luta das forças sociais pelo poder. Tornar-se senhor da memória e do esquecimento é uma das grandes preocupações das classes, dos grupos, dos indivíduos que dominaram e dominam as sociedades históricas. Os esquecimentos e os silêncios da história são reveladores desses mecanismos de manipulação da memória coletiva”. (LE GOFF, 2003,)

No âmbito da cidade, a preservação de obras de arquitetura ao longo do tempo nos serve como testemunho do poder. Inclusive construções antigas que só permanecem na cidade por se localizarem em áreas esquecidas, também representam o poder de alguns grupos e, em verdade, o fortalece na medida em que sua posição de abandono e precariedade demonstra que não é aquela a imagem a ser perpetuada e reafirma às gerações futuras a grandeza da sua força social. Nesse sentido, essas áreas se transformam, ainda que involuntariamente, em documentos no sentido atribuído por Le Goff (2003), ou seja, documento enquanto monumento fruto de imposições de sociedades históricas para criar uma determinada imagem de si. Disso decorre que estas áreas devam ser estudadas considerando as relações de força que detinham o poder no momento da sua produção e nos períodos de sua permanência na cidade.

Este tipo de abordagem histórica, na medida em que desmonta e desestrutura os discursos por trás da manutenção dessas áreas tal qual se dá na cidade corrobora não só para a compreensão das suas condições de produção e permanência, mas principalmente permite aos seus habitantes recuperá-las enquanto parte imprescindível de suas memórias coletivas e enquanto estruturas constituintes de suas identidades. A história se torna a chave de acesso à memória coletiva e, sem ela, a capacidade de esquecimento e de lembrança flutua ao belprazer de manipulações pelo controle social. 
Aqui se evidencia a distinção entre memória coletiva e história. Halbwachs, ao diferenciá-las, alegava que apesar de ambas trabalharem com o passado o que as distinguia era a forma de abordagem. Para ele, a História analisava os grupos de fora, numa posição acima deles, enquanto a memória coletiva estava inserida na consciência coletiva desses grupos. O autor considerava que a História lidava arbitrariamente com o passado através de compilações de fatos maiores que muitas vezes estavam distantes demais dos indivíduos, apresentando pouquíssimos pontos de contato com suas histórias pessoais e, por isso, a História não poderia, de maneira alguma, ser confundida com a memória coletiva. Além disso, o autor considerava inadequada a expressão "memória histórica" uma vez associa dois termos que se opõem radicalmente.

Posteriormente aos escritos de Halbwachs ${ }^{34}$, com o alargamento da noção de documento e o advento da revolução documental, os interesses da História são ampliados e ela deixa de tratar exclusivamente dos grandes feitos para ocupar-se de todos os homens, as "massas dormentes", como denominou Le Goff (2003). Nesse contexto, Foucault elabora sua argumentação a respeito do papel da História na abordagem dos documentos, deixando clara a distinção entre memória e história.

"É preciso desligar a história da imagem com que ela se deleitou durante muito tempo e pela qual encontrava sua justificativa antropológica: a de uma memória milenar e coletiva que se servia de documentos materiais para reencontrar o frescor de suas lembranças; ela é o trabalho e a utilização de uma materialidade documental (...) que apresenta sempre e em toda a parte, em qualquer sociedade, formas de permanências, quer espontâneas, quer organizadas. O documento não é o feliz instrumento de uma história que seria em si mesma, e de pleno direito, 'memória'; a história é, para uma sociedade, uma certa maneira de dar 'status' e

${ }^{34}$ Suas publicações são do início do século XX, sendo A memória Coletiva, de 1950, publicação póstuma. Maurice Halbwachs, socialista, foi preso pela Gestapo após a ocupação nazista de Paris e foi deportado para o campo de concentração de Buchenwald e, em 1945, executado. 
elaboração à massa documental de que ela não se separa." (FOUCAULT, 2000, p. 08)

Portanto, podemos entender a memória como objeto da História, como a construção social de um quadro simbólico que ajuda a compor e a reforçar a identidade individual ou coletiva. A memória é, portanto, uma operação ideológica de representação de si que guia a atuação dos indivíduos nas relações sociais e por isso, como orienta MENESES (1992), deve ser analisada no domínio das representações sociais. A História, no entanto, é operação cognitiva, procedimento intelectual e científico de questionamento dos documentos e é justamente essa ação crítica, investigativa e metodológica que transforma os documentos em monumentos (FOUCAULT, 2000).

Enquanto Halbwachs entendia que era a memória através de um mosaico de discursos distantes dos grandes feitos que organizava a sociedade, Foucault procurava apontar as estratégias de poder que compunham esses discursos atribuindo-lhes um sentido disciplinador e excludente (SANTOS, 2003). Apoiado no conceito nietzscheano de Wirkliche Histoire ${ }^{35}$ ou História Efetiva, Foucault define o papel da História justamente como o de investigar e analisar esse mecanismo.

"A história 'efetiva' faz ressurgir o acontecimento no que ele pode ter de único e agudo. É preciso entender por acontecimento não uma decisão, um tratado, um reino, ou uma batalha, mas uma relação de forças que se inverte, um poder confiscado, um vocabulário retomado e voltado contra seus utilizadores, uma dominação que se enfraquece, se distende, se

\footnotetext{
${ }^{35}$ Segundo FOUCAULT (1998), Nietzsche opõe ao conceito de História como pesquisa de Ursprung (origem) o de Wirkliche Histoire como pesquisa de Herkunft (proveniência) e de Entestehung (emergência). Como crítica ao modelo tradicional da História que procurava o início das coisas em estado de perfeição (Ursprung/origem), Nietzsche propôs um modelo de estudo que tomava a dinâmica ou as forças propulsoras da origem (Herkunft/proveniência) e quando e de que modo elas vêm à tona (Entestehung/emergência). Desta forma, a "genealogia restabelece os diversos sistemas de submissão: não a potência antecipada de um sentido, mas o jogo casual das dominações" (FOUCAULT, 1998, p. 23).
} 
envenena e uma outra que faz sua entrada, mascarada." (FOUCAULT, 1998, p. 28)

A partir do mesmo conceito, Foucault afirmava que a história é sempre um saber perspectivo já que os historiadores analisam os fatos a partir de determinado ponto de vista, por mais que não queiram revelar o momento e o lugar de onde olham. Segundo ele, o sentido histórico para Nietzsche tem consciência da injustiça desse processo e "é um olhar que sabe tanto de onde olha quanto o que olha" (FOUCAULT, 1998, p. 30). Igualmente se aproxima a este pensamento o conceito de "trabalho de enquadramento da memória", proposto por POLLAK (1992), que o define como um trabalho parcialmente exercido pelos historiadores com o intuito de enquadrar a memória aos interesses de determinados grupos, quando envolvidos em disputas pelo poder. Cabe, no entanto, a ressalva de MENESES (1998) quando este afirma que o artefato não mente, pois sua integridade física obedece a sua verdade objetiva; "os discursos sobre o artefato é que podem ser falsos" (MENESES, 1998, p. 04).

A história das cidades também pode ser montada ou enquadrada a partir de imagens que grupos dominantes pretendem transparecer para garantir seus interesses econômicos. Os discursos ideológicos do poder podem ser identificados facilmente nas cidades brasileiras ao longo de sua trajetória como, por exemplo, implantados através de medidas urbanísticas, valorização de determinadas áreas dentro da cidade, preservação de áreas e obras arquitetônicas pelo Estado, assim como pela "preservação" ou permanência de edificações e áreas decorrente do abandono e desinteresse econômico, etc.

"Parece-me que no final do século XVIII, a arquitetura começa a se especializar, ao se articular com os problemas da população, da saúde, do urbanismo. Outrora, a arte de construir respondia sobretudo à necessidade 
de manifestar o poder, a divindade, a força. O palácio e a igreja constituíam as grandes formas, às quais é preciso acrescentar as fortalezas; manifestava-se a força, manifestava-se o soberano, manifestava-se Deus. A arquitetura durante muito tempo se desenvolveu em torno destas exigências. Ora, no final do século XVIII, novos problemas aparecem: trata-se de utilizar a organização do espaço para alcançar objetivos econômico-políticos." (FOUCAULT, 1998, p. 211)

A discussão sobre a seletividade entre o preservar e o demolir na ação dos órgãos responsáveis parece querer ser tomada como neutra em relação ao papel político exercido pela memória. Além disso, pretendem que também neutra seja a própria memória resgatada, mascarando os interesses que norteiam a atuação do Estado ao consagrar um lugar em detrimento de outros.

JARDIM (1995) afirma que o Estado brasileiro tem sido mais identificado com o novo e como um projeto de futuro do que com a memória que lhe pertence ou com uma apreensão plural da realidade social do país. Esta situação, segundo ele, só acaba por reificar a produção do esquecimento e por anular a efetivação da cidadania.

Entretanto, vale ressaltar que ao contrario dos discursos sobre o engessamento das cidades através da preservação, a produção do novo é fundamental não só para a dinâmica urbana como também para a própria reelaboração da memória nos espaços de permanência, desde que essa substituição seja socialmente responsável. Meneses (1992) propõe duas condições para essa ação:

"A primeira é a verificação do esgotamento do potencial funcional do bem em causa, a impossibilidade não só de maximizá-lo (o que, com as tecnologias modernas, torna-se mais e mais factível), mas também de reciclá-lo ou simplesmente mantê-lo. A seguir, deve-se responder satisfatoriamente a duas perguntas seminais: a quem interessa o novo? Quem responde pelo ônus? Esta postura não comporta, pois, rigidez ou imobilismo; pelo contrário, está aberta ao poder de fecundação, criação, ampliação do novo, não a suas forças de degradação." (MENESES, 1992) 


\section{II.5. Memória e esquecimento: o caso da Avenida Conselheiro Nébias.}

O estudo das permanências no âmbito da cidade permeia, necessariamente, a compreensão dos processos que as envolveu na sua formação e manutenção. Vimos que determinadas áreas são mantidas na cidade simplesmente por não serem, ainda, alvos do mercado e que sua posição de abandono é a afirmação da imagem de dominação de alguns grupos, que a utilizam para perpetuar sua posição social.

O trecho estudado da Avenida Conselheiro Nébias exemplifica perfeitamente essa condição de permanência, demonstrando ao longo da sua trajetória o poder que as classes dominantes exercem sobre a cidade, capaz de fazer com que áreas originalmente valorizadas atinjam o total abandono. Essa área tratada com descaso pelo Poder Público durante anos - e a isso se deve sua permanência na cidade, está sendo destruída atualmente para responder aos interesses do mercado imobiliário, após seu solo urbano ter se tornado foco das estratégias de lucro. O discurso oficial, no entanto, acelera o processo ao não reconhecer a área como importante suporte da memória pública permitindo e incentivando a substituição e verticalização da área através de instrumentos previstos no Plano Diretor de 1998. Contudo, consagra como únicas detentoras da "verdadeira" imagem da cidade as áreas ligadas à fase de apogeu da economia cafeeira.

Neste sentido, entende-se que há o desejo de manutenção da memória de apenas alguns grupos sociais, não que sua memória tenha menor importância, mas não pode ser considerada como única e universal dentro da pluralidade de grupos sociais de que a cidade é composta. Além disso, o aumento 
do valor do solo urbano no trecho em estudo - decorrente de diversos fatores, principalmente da escassez de solo urbano livre para novas construções, faz com que a manutenção da memória esteja também subordinada a interesses lucrativos. Assim, são implantados discursos que promovam a necessidade de modernização da área através da renovação, menosprezando seu valor memorial, com o objetivo de atender a reivindicações do mercado imobiliário sobre a rentabilidade do solo. Essas ações que beneficiam, na maior parte das vezes, apenas a um seleto grupo são legitimadas pelo Poder Público através de medidas urbanísticas.

“(...) preservar é uma forma de resistência a expropriação generalizada que exercem as forças econômicas nas sociedades como as capitalistas, em que o espaço se reduz a mercadoria e o domínio público da cidade assume o valor de ficção. Nesses termos, ainda, preservar é uma forma de reapropriar-se da cidade." (MENESES, 1978, p. 46)

Deste modo, a eleição das áreas que devem ou não permanecer na cidade ficam subordinadas ao interesse de alguns grupos sociais que, através de discursos ideológicos, garantem a manutenção de determinadas memórias quer seja por interesses econômicos, quer seja por estratégias de controle social. Segundo Pollak (1989), a disputa pela preservação das memórias está muito mais ligada a problemas entre grupos minoritários e sociedade englobante do que à oposição entre sociedade e um Estado dominador.

Portanto, há que se ter claro que a cultura e sua preservação através da memória são direitos de todos os cidadãos e que cabe ao Poder Público assegurar-lhes o cumprimento sem que sejam excluídos grupos ou classes ou que Ihes sejam garantidos como um "favor". Por isso, ao ato da preservação deve ser incontestavelmente associado o direito à cultura através do valor cultural, sendo de 
fundamental importância a compreensão de que este valor é tão ou mais excepcional em áreas ou obras de arquitetura como qualquer outro.

Ao Poder Público, através de suas atuações na cidade pelos órgãos de preservação e de planejamento urbano, cabe o dever de combater a amnésia social, fruto da sociedade de consumo, que impede o envelhecimento das coisas através da obsolescência e das substituições aceleradas. Enquanto responsável pelo bem-estar dos cidadãos e pela organização da economia, a atuação estatal na preservação da memória pública deve deixar de ser uma determinação sobre o social para se tornar uma determinação para o social, a fim de que o patrimônio possa funcionar como "veículo que contribua para devolver a cidade ao cidadão, transformando-a, efetivamente, no lugar de todos”. (MENESES, 1978, p. 46) 


\section{CAPÍTULO III}

Direito cultural na preservação urbana: alusão a teoria de Alöis Riegl

"O que acontece é que o melhor guardião de um bem cultural é sempre seu dono (as comunidades locais)." 


\section{III.1. Introdução.}

Neste capítulo, examinam-se alguns aspectos teóricos da obra de Alöis Riegl tendo em vista vincular a questão cultural à construção de identidades urbanas pelo Patrimônio Histórico.

A compreensão de que o valor cultural é atribuído ao objeto pelas práticas sociais que o envolvem e que os atores sociais são elementos imprescindíveis e indispensáveis para a compreensão do significado contido no bem patrimonial esclarece um dos principais pontos desenvolvidos nessa pesquisa que é a questão dos "direitos culturais" e do livre acesso aos bens.

O termo "direito cultural" será usado para designar a relação de posse que o sujeito histórico trava com alguns objetos, com os quais tem uma ligação afetiva, e que culmina em um desejo de manutenção desses objetos com a garantia do Estado. Também concorrem para a discussão, hipóteses sobre a dominação cultural exercida por alguns agentes no sentido de impedir ou dissimular a prática desse direito por todos os grupos que compõem a sociedade.

Sendo assim, o pensamento de Alöis Riegl torna-se um dos primeiros interlocutores dessa questão no discurso do patrimônio, na medida em que o historiador de arte vienense foi um dos primeiros a elaborar um sistema de valores atribuídos aos monumentos que levasse em conta seu contexto histórico. 


\section{III.2. Alöis Riegl e a questão do direito cultural.}

Filósofo, historiador e jurista. Esta era a formação daquele que foi um dos primeiros a abordar o monumento como objeto social mergulhado em significados atribuídos pela sociedade.

Alöis Riegl (1858 - 1905) elaborou um sistema de valores que considerava as diversas maneiras de percepção e recepção dos edifícios de acordo com o momento histórico em que estavam inseridos. Segundo Choay (2001), o pensamento riegliano é estruturado na oposição de duas categorias de valores descritas por ele: valor de rememoração, ligado à memória, e valor de contemporaneidade, pertencente ao presente.

"Ele (Riegl) se vale de todo o seu saber e experiência como historiador de arte e conservador de museu para empreender uma análise crítica da noção de monumento histórico. Este não é abordado apenas sob uma perspectiva profissional, como a de Boito, mas tratado como um objeto social e filosófico. Só a investigação do sentido ou dos sentidos atribuídos pela sociedade ao monumento histórico permite fundar uma prática. Daí uma dupla abordagem - histórica e interpretativa." (CHOAY, 2001, p.168)

Dessa forma, o estudo comparativo dessas variáveis contidas no monumento culminaria em diferentes recomendações para sua preservação. Para Riegl, a oposição entre as possibilidades de preservar implica em escolhas que devem ser embasadas em um criterioso julgamento, de acordo com o contexto social e o momento em que se insere. Assim, ele aproxima ao ato de restaurar a questão cultural antecipando idéias defendidas por Cesare Brandi e o restauro crítico. Na introdução espanhola ao Problemas de Estilos ${ }^{36}$, Ignasi de Solà-Morales afirma que a teoria riegliana significou "liberação do preconceito de perfeição

\footnotetext{
${ }^{36}$ Título original: Stilfragen: Grundlegungen zu einer Geschichte der Ornamentik. Obra riegliana de 1893, antecessora ao Denkmalkutus.
} 
ahistórica ou do preconceito de progresso e decadência cíclicos, para introduzir uma explicação estrutural inerente a cada diferente momento cultural." (SOLÀMORALES, 1980, p.12)

Choay (1984 apud FONSECA, 2005, p.52) também ressalta a excepcionalidade do tratamento riegliano ao monumento histórico, na introdução francesa ao Der moderne Dekmalkultus ou O culto moderno aos monumentos, obra riegliana de 1903:

"Único no seu gênero desde sua aparição, esse pequeno texto continua até hoje inigualável. (...) Basta indicar que, pela primeira vez na história da noção de monumento histórico e de suas aplicações, Riegl toma distância. Sua posição de observar não é nem a dos arquitetos, que desde Alberti integram a questão do monumento histórico na teoria da sua disciplina, nem a dos homens de letras, que fizeram do patrimônio monumental o objeto de cruzada passional. Graças a essa distância, ele pôde, antes de qualquer outro, realizar o inventário dos valores não ditos e das significações não explicitadas, subjacentes ao conceito de monumento histórico. De imediato, este perde sua pseudotransparência de dado objetivo. Toma-se o suporte opaco de valores históricos transitivos e contraditórios, de procedimentos complexos e conflitantes."

O Denkmalkultus é estruturado em três partes nas quais são desdobrados os valores atribuídos aos monumentos: na primeira são apresentados os valores monumentais e sua evolução histórica, na segunda Riegl trata dos valores rememorativos em relação ao culto aos monumentos e na terceira parte são expostos os valores de contemporaneidade também em relação ao culto aos monumentos.

A definição de monumento é apresentada na primeira parte do

Culto e expõe o cerne do pensamento documental riegliano ao tratar o monumento como fonte de conhecimento. É sob essa ótica que o autor define monumento histórico e artístico afirmando que o primeiro, mais amplo, engloba o segundo, não 
sendo possível que haja um monumento artístico que não seja histórico por demonstrar o estado evolutivo das artes plásticas. Segundo Fonseca, para Riegl "o monumento artístico deve ser compreendido como um monumento da história da arte, e seu valor, considerado desse ponto de vista, é menos artístico que histórico." (FONSECA, 2005, p. 65)

Também é evidenciada a estrutura do pensamento riegliano, adepto ao pensamento evolutivo, de encadeamento de situações e fatos passados que ele descreve como sendo o pensamento moderno:

"Chamamos histórico a tudo que tenha existido alguma vez e já não existe mais. Segundo os conceitos mais modernos, a isso vinculamos a idéia de que o que alguma vez existiu não pode voltar a existir, e tudo o que existiu constitui um elo imprescindível e indispensável de uma cadeia evolutiva, ou seja, que tudo esta condicionado pelo anterior e não poderia ocorrer como ocorreu se não o houvesse precedido aquele elo anterior." (RIEGL, 1999, p. 24)

Na segunda parte do livro - Valores rememorativos em relação ao culto aos monumentos, Riegl apresenta os seus três primeiros valores:

1. Valor de antiguidade - é o valor mais democrático de todos os apresentados no Culto. Isto porque, segundo o autor, o valor de antiguidade demonstra a Natureza atuando nas obras humanas e isso faz com que qualquer pessoa seja capaz de reconhecer nesse processo o ciclo natural da vida humana, desde a origem à decadência e fim. Esse fator faz com que a intervenção humana no estado atual do monumento seja uma prática proibida sob o ponto de vista do valor de antiguidade. Como afirma Riegl (p. 53) "o culto ao valor de antiguidade atua contra a conservação do monumento", no entanto, é importante frisar que (p. 54) "nada mais distante do culto ao valor de antiguidade do que querer acelerar esta destruição". 
2. Valor histórico - em oposição ao valor de antiguidade, o valor histórico presa pela conservação do monumento, preservando-o das possíveis marcas da velhice produzidas pelas leis naturais. Aqui, o que interessa é a melhor visualização do monumento no seu estado de gênesis, enquanto fonte de conhecimento de uma etapa criativa da história da humanidade. Para que isso seja possível, o autor afirma que o historiador deve preencher (p. 57) "os vazios que as influências da natureza produziram na forma originária no transcurso do tempo", sem, no entanto, cometer um falso histórico, para que sejam possíveis investigações futuras. Para tanto, a relação entre o valor de antiguidade e o valor histórico se torna conflituosa e, como alerta Riegl, (p. 64) "o fundamental consiste em evitar, a princípio, o conflito entre os valores", o autor propõe que sejam feitas cópias dos monumentos para resguardar a fonte de investigação científica sem que o original perca o seu valor para o culto a antiguidade.

3. Valor rememorativo intencionado - esse valor tem por princípio manter a vivacidade do monumento enquanto elemento de rememoração de façanhas ou atos passados, sem que se torne passado, mas elemento vivo na consciência futura. Para demonstrar o caráter de imortalidade desse valor, Riegl se utiliza de termos como eterno presente e permanente estado de gênesis em suas definições, o que o leva a concluir que o principal postulado desse valor é a restauração.

Os próximos valores descritos por Riegl, na terceira parte do Culto Valores de contemporaneidade em relação ao culto aos monumentos, consideram a obra não como monumento, mas como obra contemporânea (p. 71) "recém criada, e a exigir, portanto, também do monumento antigo a aparência externa de toda obra 
humana nova em estado de gênesis, ou seja, a impressão de algo perfeitamente completo e não afetado pelas destrutivas forças da natureza". Esse posicionamento pode levar a conflitos entre esse valor e o valor de antiguidade, a não ser que haja renúncia de um dos lados.

1. Valor instrumental - o postulado fundamental desse valor é a conservação dos edifícios antigos com a finalidade de mantê-los úteis ao homem sem colocar em risco sua vida ou saúde. Sendo assim, Riegl não se posiciona com relação ao tratamento a ser dado ao monumento, desde que ele se torne novamente prático e útil. Dessa forma, pode-se pensar sobre a possibilidade de conflito entre o valor de antiguidade e o valor instrumental, no entanto, Riegl adverte para o fato de que um edifício não pode oferecer riscos à vida humana o que faz prevalecer nesses casos, acima da necessidade ideal do valor de antiguidade, o valor de bem-estar físico. Riegl ainda considera a hipótese de existir uma cópia do monumento para que o original, livre da utilização e do uso prático, pudesse desfrutar daquele processo natural de envelhecimento. Nesse caso, ele alerta para o fato de que sem a utilização humana do monumento (p. 75) "se perderia de modo insubstituível uma parte essencial daquele livre jogo das forças naturais, cuja percepção dá origem ao valor de antiguidade". Alguns raros, como por exemplo, obras da Antiguidade Clássica, cuja utilização prática já não existe há tempos, não são justificadas por esse argumento. Assim, Riegl estabelece uma linha divisória entre monumentos utilizáveis e não utilizáveis em relação aos quais deve sair vencedor o valor que tenha o apoio de outros valores, variando de caso a caso. 
2. Valor artístico - segundo o autor, todo monumento possui um valor artístico relativo à vontade de arte moderna, denominada por ele de kunstwollen. A vontade de arte moderna apresenta duas classes de exigências a serem cumpridas pelos monumentos para que se lhes conceda o valor artístico, apesar de que ele reconhece a impossibilidade de um monumento responder integralmente a essas duas exigências. A primeira é que o monumento deve apresentar-se por inteiro, sem nenhum processo de deterioração aparente, por se tratar de algo recém criado já que o valor artístico é algo contemporâneo - moderno, na expressão riegliana. A segunda exigência diz respeito às diferenças de concepção, cor e forma, que diferenciam a vontade de arte moderna das anteriores, considerando que não se trata de uma exigência objetiva, pois encontra-se em permanente mudança. A partir dessas duas exigências subdividem-se dois outros valores, a partir do valor artístico:

Valor de novidade - esse valor diz respeito ao caráter de recém criado que deve ser mantido no monumento para satisfazer a moderna vontade de arte, liberando-o de todas as marcas de deterioração. Dessa forma, o valor de novidade só pode ser mantido opondo-se ao valor de antiguidade e, segundo Riegl, esse conflito supera todos os outros já mencionados. Aqui Riegl se posiciona com relação à questão do belo: para ele, as massas só entendem como belo o novo e completo e por isso o valor de novidade atinge a grande massa, principalmente aqueles que têm pouca cultura.

Valor artístico relativo - este valor está baseado na prerrogativa que obras passadas também podem ser analisadas sob o ponto de vista de sua concepção artística, forma e cor. Se acaso essa análise for positiva, ou seja, se o 
monumento satisfizer a vontade de arte moderna torna-se necessária sua conservação e, em alguns casos, a restauração integral do monumento para que este não perca o vigor artístico, o que sob a ótica do valor de antiguidade, causaria conflitos com seus postulados. Sobre as obras de arte antigas, Riegl afirma que algumas têm apenas alguns traços em comum com a moderna vontade de arte. Segundo o autor, esses traços que sintonizam com a vontade de arte contemporânea se (p. 92) "destacam de um modo tão intenso e vigoroso, que os demais nos parecem superados e vencidos por eles". Assim, esses traços que não se aproximam da vontade de arte moderna adquirem uma importância tão grande que os artistas contemporâneos nunca seriam capazes de alcançar a mesma valorização que os artistas antigos, pois os atuais apenas dispõem da moderna vontade de arte. Por isso ele afirma que o valor artístico relativo, diferentemente do valor de novidade, (p. 80) "só pode ser apreciado pelos que têm formação e cultura estética”.

Kühl (2005) esclarece que o Culto moderno aos monumentos fazia parte de um conjunto de três textos organizados com o intuito de formular uma legislação para conservação na Áustria. Segunda a autora, o Culto é a fundamentação teórica da proposta de lei e constitui a primeira parte do projeto, seguido pela proposta de lei para a tutela dos monumentos (segunda parte) e por uma parte final contendo disposições para a aplicação dessa lei. A implementação da lei teria sido concretizada algumas décadas depois, com outro caráter.

Para Riegl, o monumento pode ser encontrado desde as mais remotas épocas e costumava visar à rememoração. Ele os define como "uma obra realizada pela mão humana e criada com o fim específico de manter façanhas ou destinos individuais (ou conjunto destes) sempre vivos e presentes na consciência 
das gerações vindouras" (RIEGL, 1999, p.23) e, por isso, Riegl os nomeia de monumentos intencionais. No entanto, o autor aponta para o fato de que aqueles monumentos hoje considerados por nós como obras de valor histórico e artístico não são frequentemente produzidos com a finalidade de reviver fatos passados e, por isso, Riegl os denomina de não-intencionais, já que “(...) o caráter e significado de monumentos não correspondem a essas obras em virtude do seu destino de origem, mas somos nós, sujeitos modernos, quem os atribuímos." (RIEGL, 1999, p.29)

A partir dessa afirmação do autor, concluo que o processo classificatório do que se torna ou não monumento baseia-se em um julgamento de um sujeito histórico. Apesar dos rigorosos métodos e artifícios para tal seletividade, trata-se de um critério subordinado aos interesses de algum grupo social que assume o encargo de analisá-los e classificá-los. Levanto a possibilidade de que nesse grupo, assim como em qualquer outro que ocupasse seu lugar, está embutida uma ideologia de auto defesa, mesmo que aparentemente eles representem valores universais - a não ser que exista alguma forma de participação popular, principalmente daqueles grupos diretamente envolvidos, no processo de seleção e proteção de bens.

Esse pensamento me sugere algumas inquietações no que se refere à eleição do patrimônio na contemporaneidade:

1. Existe uma única ideologia (se sim, qual é?) defendida no processo de seleção dos bens patrimoniais ou na categorização do que é monumento para o sujeito histórico do século XXI?

2. O Poder Público, na forma de determinados órgãos dotados de autonomia legal para a formação e manutenção da História Pública e, consequentemente, de 
identidades, é representativo da multiplicidade cultural de uma coletividade urbana ou nacional?

3. Tais órgãos legislam e atuam em favor da coletividade buscando a participação das diversas ideologias defendidas por todos os grupos que compõem a cidade ou são subordinadas a uma única ideologia partidária que, no mandato considerado, defenda interesses de alguns grupos?

4. E as inúmeras influências do setor imobiliário? Qual é o peso desse setor na seleção do que vai ou não se tornar patrimônio perante o Estado?

Em todos os questionamentos a resposta que se procura é se existe uma atuação estatal no sentido de garantir as condições necessárias à produção de cultura e ao exercício do "direito cultural" ${ }^{\text {"77 }}$ por todos os cidadãos.

Fonseca (2005) chama essa postura estatal de "Estado em ação" e alerta para o fato de que essa idéia implica, necessariamente, em heterogeneidade, luta pelo poder e conflito de interesses tanto entre Estado e sociedade quanto internamente, na máquina estatal. Segundo ela, no caso de países onde nem mesmo a cidadania é um bem coletivo, como no Brasil, se faz necessária uma atuação mais ativa e abrangente do Estado.

"Trata-se não só de defender determinados valores, como de criar condições para implementá-los numa sociedade onde os direitos mínimos da cidadania, na prática, são exercidos por poucos. Ou seja, considerar todos os cidadãos como homens de cultura, assim como propunha Gramsci, em condições de exercer os direitos culturais, e atuar no sentido de converter esse princípio - que no caso do Brasil é ainda um ideal - em realidade." (FONSECA, 2005, p.47)

\footnotetext{
${ }^{37}$ A noção de "direito cultural" será abordada ao final do capítulo.
} 
Apesar de não ser atual, a legitimação do patrimônio que agrega valor às multiplicidades históricas ainda é pouco usual nos processos de categorização do que é monumento. Sob esse foco, Riegl demonstra-se atual ao apresentar sua visão diferenciada sobre as artes e os monumentos de diferentes períodos dentro de uma sucessão de acontecimentos. No Denkmalkultus, ele defende correntes artísticas como as não clássicas considerando que todas as manifestações artísticas são importantes no percurso da história por demonstrarem um estado evolutivo das artes plásticas em determinado momento. Essa estrutura de pensamento, evolutiva, constitui a base da argumentação riegliana como demonstra Campos (2006) sobre o posicionamento do autor em renegar qualquer tipo de desprezo artístico. Riegl opõe-se a pressupostos defendidos por alguns de seus contemporâneos de que há um revezamento entre períodos de apogeu e declínio de estilos; como por exemplo, o preconceito da historiografia de sua época sobre a produção artística do Império Romano e do barroco desprezados ao serem subjugados a parâmetros de períodos artísticos anteriores.

$D^{\prime}$ Agostinho ${ }^{38}$ explica que, no pensamento riegliano, para avaliar uma obra é preciso operar com o plano da especulação estética, abdicando de valores próprios e tentando apreender, no contexto da obra, o que se perseguia. Segundo ele, é preciso compreender a lógica visual daquele período, já que a relação daquele grupo com o espaço e com o todo, com a ambiência, com o ritmo e movimento é outra, pois só naquele período existiu aquela intencionalidade.

\footnotetext{
38 D'AGOSTINO, Mario Henrique Simão - esclarecimentos na palestra "Abordando as teorias estéticas e o neokantismo da primeira metade do século XX", apresentada no "Seminário de estudos sobre Cesare Brandi: a Teoria da Restauração", realizado na FAU Maranhão em setembro/2006, sob responsabilidade das Profas. Dras. Beatriz Mugayar Kühl e Maria Lucia Bressan Pinheiro.
} 
A partir dessa argumentação da evolução estética atrelada a uma linearidade histórica é que Riegl desenvolve o conceito de Kunstwollen - traduzido a priori por vontade artística ou formativa, mas que contempla em si a intencionalidade estética do período de sua criação. Partindo-se disso, então, seria contraditório ao cerne do conceito o menosprezo artístico vinculado à flutuação estilística, processo descrito anteriormente, pois disso conclui-se a nulidade do impulso criativo em alguns períodos.

Assim, considera que por mais precária que seja uma manifestação artística, se for "o único testemunho conservado da criação de sua época, apesar de sua precariedade haveríamos de considerá-la como um monumento artístico absolutamente imprescindível”. (RIEGL, 1999, p. 25)

Importante ressaltar que à noção de kunstwollen está embutida uma dúplice historicidade entre a formulação da obra e o momento presente de sua fruição, ou seja, sugere um embate entre a intencionalidade do período da criação da obra e o que ela desperta no espectador em outro momento histórico, dotado de outra intencionalidade artística. Para D’Agostinho, é dessa tensão entre presente e passado intrínseca a kunswollen que surge a questão dos valores em Riegl; os valores se atritam e sobressaem aqueles que melhor justificam a atuação no presente.

Nesse sentido, Riegl considera a inexistência de um monumento artístico universal ao afirmar que não há valor artístico absoluto, somente um relativo, que se aproxima das exigências da vontade de arte (Kunstwollen) moderna, variando "incessantemente de um sujeito a outro e de um a outro momento" (RIEGL, 
1999, p. 28). Riegl explica que desde o início do século XX foi descartada a crença em um ideal artístico objetivo, cultuado até o século XIX.

Segundo Bayón (1970 apud SILVA, 2006, p.67), a crítica moderna de arte apresentou duas vertentes principais: a francesa e a alemã; a primeira ligada ao aspecto subjetivo da atividade do sujeito na experiência artística, e a segunda voltada, em geral, para a possibilidade de tornar objetiva a vivência estética e seu julgamento. Assim, a autora Silva defende que para os pensadores alemães inspirados nos princípios kantianos "todo dogma artístico baseado no respeito absoluto de um estilo" (SILVA, 2006, p.67) tornou-se algo ultrapassado pela crítica de arte.

Por isso, Riegl afirma no Denkmalkultus que toda obra artística passada deixa de ter valor exclusivamente para a arte, tornando-se valiosa também para a história da arte devido à concepção, forma e cor empregadas. Portanto, segundo o autor, não se pode falar de monumentos históricos e artísticos, senão somente de monumentos históricos (RIEGL, 1999, p. 28).

Essa característica do pensamento riegliano de tratar o monumento como documento é reafirmada no projeto de lei do qual o Culto moderno aos monumentos fazia parte, pois, como alerta Kühl, apesar do Culto ser a fundamentação teórica do projeto, Riegl desconsidera a aplicação dos outros valores descritos na atuação sobre os monumentos: "sua proposta de lei é baseada essencialmente no respeito ao valor de antiguidade" (KÜHL, 2005, p. 04).

Nesse ponto, o pensamento de Riegl parece se afastar das teorias desenvolvidas posteriormente acerca da preservação, principalmente do pensamento de Cesare Brandi, fundador do Instituto Central de Restauração (ICR) 
de Roma, em 1939. O pensamento brandiano, descrito na Teoria da Restauração, se baseia no reconhecimento fundamental do monumento como obra de arte, definido por ele: “(..) a restauração constitui o momento metodológico do reconhecimento da obra de arte, na sua consistência física e na sua dúplice polaridade estética e histórica, com vistas à sua transmissão para o futuro" (BRANDI, 2004, p.30).

Assim, tem-se a sensação de que, enquanto para Riegl o caráter fundamental da obra é seu valor histórico, suprimindo o estético, em Brandi o estético é que sobrepõe o histórico. Trata-se, no entanto, de uma afirmação questionável, já que o que ocorre é que em Riegl essas instâncias não são separadas em categorias distintas. Isso se dá porque o autor considera a instância estética e histórica contidas mutuamente, já que para ele toda obra de arte é um fato histórico e todo monumento histórico é também um monumento artístico:

“(...) pois inclusive um monumento escrito tão insignificante como, por exemplo, uma folhinha de papel com uma breve nota sem importância, além de seu valor histórico sobre a evolução da fabricação do papel, a escrita, os materiais para escrever, etc., contêm toda uma série de elementos artísticos: a forma externa da folhinha, a forma das letras e o modo de agrupá-las.” (RIEGL, 1999, p. 25)

Já em Brandi, para que ocorra o processo de 'reconhecimento' da obra de arte, faz-se necessário manter a integridade imagética da obra, ou seja, manter a unidade da imagem da obra sem, no entanto, perder suas particularidades históricas e estéticas - vinculadas ao conceito de autenticidade. Assim, o autor articula, dialeticamente, as instâncias histórica e estética sem que haja exclusão ou supressão mútua delas.

“(...) as instâncias estética e histórica são analisadas, do ponto de vista metodológico, interagindo através de dialética, mas de modo algum 
possuem autonomia absoluta, não são destacáveis, são faces de um mesmo bem multifacetado, são dois aspectos coexistentes e paritários.

Deve-se recordar a dúplice polaridade estética e histórica da definição de Brandi e que a ação deve ser feita 'sem cometer um falso artístico ou um falso histórico, e sem cancelar nenhum traço da passagem da obra de arte no tempo."' (KÜHL, 2005, p. 09)

Assim, conclui-se que os pensamentos brandiano e riegliano não são excludentes, mas se aproximam, visando manter, da melhor maneira, elementos culturais que formam e reforçam a identidade nas cidades. Como ressalta Kühl, pode-se inclusive formular hipóteses sobre a influência de Riegl sobre a Teoria da Restauração, já que ele foi um dos primeiros a considerar as formas de recepção, percepção e fruição dos monumentos através dos valores descritos no Culto (desenvolvidos em Brandi como unidade imagética):

\begin{abstract}
“O 'valor de antiguidade', para sua eficácia, depende da preservação escrupulosa das várias estratificações da obra e inclusive das marcas da passagem do tempo, apreciando-se as formas de dissolução. Já ao 'valor histórico', interessa deter toda degradação a partir do momento em que se realiza a intervenção, perenizando a imagem e o documento que se recebeu no presente. Ao 'valor de rememoração intencional' interessa a perenidade do estado original, atendo-se ao ato em si da edificação do monumento. No que se refere aos valores de 'contemporaneidade', Riegl afirma que a maior parte dos monumentos pode responder às expectativas contemporâneas dos sentidos ou do espírito; desse modo, são subdivididos em 'valor de uso' e 'valor artístico', e este último se reparte em 'valor como novidade' e 'valor artístico relativo'”. (KÜHL, 2005, p. 16)
\end{abstract}

Como mostra Campos (2006), Riegl influenciou a teoria da arte e historiógrafos como Erwin Panofsky e Ernst Cassirer entre outros e aduz um importante fato a ser ressaltado: assim como Brandi, Riegl não desconsidera a instância estética na sua discussão sobre valores. Com a determinação do conceito de Kunstwollen apenas propõe cautela nas relações de "interdependência entre a experiência figurativa e espacial e o sentido vital que permeia uma determinada época”. 
Assim, para a compreensão do ideário riegliano é fundamental o conhecimento de tal conceito, já que o interesse histórico e a estética de Riegl são justificados no Kunstwollen. Isso se dá porque ele agrega ao determinismo artístico, aceito como o agente da evolução das formas, a originalidade estilística de cada período, obtida através de intencionalidades formais que guiariam as etapas de diferenciação das artes.

O determinismo artístico afirmava que a origem das formas artísticas e dos ornamentos era produto exclusivo de matéria, técnica empregada e do uso a que se destinava a obra. Essa concepção da produção mecânica da obra de arte era atribuída a Gottfried Semper ${ }^{39}$, o que fez com que sua teoria fosse contraposta a Riegl e à concepção de produção artística vinculada à Kunstwollen, como podemos ver em Schlosser (1996 apud SILVA, 2006, p. 76):

"As idéias de Riegl são justamente o contrário daqueles teoremas naturalistas. (...). Seu critério, se assim pode-se dizer, tem um caráter vitalista; parte de um instinto formal inerente a nós, um 'algo no homem, que nos permite encontrar prazer na beleza das formas e que criou livre e independentemente as combinações geométricas de linhas, sem introduzir primeiro um vínculo material'. Se Semper considerava a obra de arte como produto da união de finalidade de uso, matéria-prima e técnica, Riegl, ao contrário, via a obra como o 'resultado de uma vontade artística determinada e consciente de seus objetivos' (...)."

Apesar dessas afirmações sobre a oposição das teorias semperianas e rieglianas, na introdução ao Problemas de Estilo, o próprio Riegl apresenta uma posição menos radical com relação a Semper:

"A teoria da origem técnico-material dos mais antigos ornamentos e formas artísticas costuma-se atribuir a Semper. Faz-se isso com a mesma ou, melhor dizendo, com tão pouca razão como se identifica o moderno

${ }^{39}$ Segundo Ignasi de Solà-Morales, na introdução espanhola de Problemas de estilo, Gottfried Semper, arquiteto - que além de teórico era também construtor, buscava a explicação dos tipos essenciais das formas artísticas nas técnicas empregadas na sua origem e evolução, ou seja, usava a teoria de Darwin para explicar as transformações nas obras de arte. 
darwinismo com Darwin (...). Mas, como é o caso entre darwinistas e Darwin, da mesma forma deve-se distinguir rigorosamente entre semperianos e Semper. Enquanto Semper disse que na origem de uma forma artística entram em consideração matéria e técnica, os semperianos sustentam de imediato que a forma artística é um produto de matéria e técnica. (...) Semper, seguramente, seria o último a substituir a livre vontade criadora por um desejo de imitação essencialmente mecânicomaterialista. Mas subsistia o erro de que esta era a idéia pura do grande artista e mestre Semper." (RIEGL,1980, p.2)

Dentro dessa perspectiva, separar a obra de arte ou Kunstwerk do seu processo de criação seria impossível e fatal, já que o conceito de Kunstwollen remete a lógica da produção artística a uma totalidade cultural que não deve ser ignorada. Silva (2006) acrescenta que essa vontade de arte ou vontade de forma se opõe a um "poder de arte" - entendido como certa capacidade técnica de imitar a natureza, e que essa vontade artística é o princípio da arte que se repete sempre, porém cada um dos estilos, dentro da evolução, expressa em diferentes maneiras o modo de perceber e sentir a forma.

“A noção de 'Kunstwollen' tornou-se fundamental para a concepção moderna de arte, pois justifica que, por detrás dos estilos, estaria uma torrente profunda que os informa: é a atitude volitiva que se traduz no 'fazer plástico'." (SILVA, 2006, p. 73)

A sucessão de estilos se deve, então, a substituição dos critérios de valor vigentes por outros novos. Para Silva (2006), essas mudanças de estilos seriam, na verdade, mudanças nas idéias estéticas e descobrir os modos pelos quais os critérios de valor mudam no transcorrer da história se tornou fundamental para Riegl, já que aí está a principal característica da escola de Viena, criada por ele e Wölfflin. 
Alöis Riegl e Heinrich Wölfflin desenvolveram a estética formalista ${ }^{40}$ dotando-a de sentido histórico. Segundo Sola-Morales, Robert Zimmermann, discípulo do formalismo de Herbart, foi o mestre mais influente em filosofia, na formação do pensamento riegliano. Outra abordagem formalista que também influenciou Riegl e Wölfflin foi a linha da visualidade pura, teoria desenvolvida com maior expressão por Konrad Fiedler ${ }^{41}$ e que partia da distinção kantiana entre percepção subjetiva, produzida pelo prazer ou pela dor, e a percepção objetiva - a qual a arte se enquadraria, e que é a representação de uma coisa através da construção sensível.

"A linha da visualidade considera a arte como um fato do conhecimento, ou seja, na arte o sujeito toma consciência da confusão das coisas visíveis e atribui-lhe uma forma. (...) A realidade não existe de modo independente desse ato formativo de nossa consciência cognitiva." (SILVA, 2006, p. 71)

Para alguns autores, diferentemente da posição de Riegl, o formalismo de Wölfflin era mais radical e enfatizava a função visual do homem, bastando para ele descrever as obras a partir de algumas categorias visuais. Segundo Silva (2006), entre Fiedler, Riegl e Wölfflin, esse último é o que despende maior atenção aos símbolos visíveis da obra como linha, cor, composição, materiais empregados, etc.

\footnotetext{
40 Teoria cujo maior expoente foi Johann Herbart que estudava a forma pela forma através de princípios kantianos, sendo considerado o precursor da visualidade pura de Fiedler. Mireia (1982 apud SILVA, 2006, p.69): "o formalismo parte do princípio da 'arte pela arte', as obras de arte são consideradas como formas com um conteúdo significativo próprio, que devem nos levar a fixar algumas 'constantes', escolas, nações ou etnias."

41 Segundo a autora Silva (2006), Riegl não chegou a conhecer a obra de Fidler, apesar de compartilhar com ele os princípios do neokantismo.
} 
Riegl, no entanto, não dissocia a forma do conteúdo no sentido de não descontextualizar o que seria de ordem visual do interesse de ordem ideológica, ou seja, do seu conteúdo cultural e histórico.

De maneira geral, no período que compreende o final do século XIX e início do século XX, segundo as autoras Choay (2001) e Külh (2007), foi dada maior atenção aos aspectos documentais dos monumentos provocando

mudanças nos procedimentos de restauração, no que diz respeito à manutenção das marcas da passagem do tempo acumuladas no bem. Choay determina entre os anos de 1820 e 1960 o período de consagração dos monumentos, tendo como principal fator desencadeador do processo a industrialização que, além de proporcionar o desenvolvimento da restauração como método técnico rigoroso, ainda acelerou o estabelecimento da proteção legal ao patrimônio. No ano de 1960, segundo Choay, dá-se o término desse período de consagração do monumento marcado pela redação da Carta de Veneza pelo ICOMOS - Conselho Internacional dos Monumentos e dos Sítios, criado em 1964 por recomendação da Unesco. Choay afirma que a publicação desse documento "marca a retomada, depois da Segunda Guerra Mundial, dos trabalhos teóricos relativos à proteção dos monumentos históricos, no contexto de um público internacional mais amplo." (CHOAY, 2001, p. 125)

O pensamento riegliano reflete as perspectivas desse período, relembrando que para o autor os monumentos deveriam ser vistos como elementos de rememoração dotados de sentido cultural pela passagem do tempo.

Em meio a sua escala de valores, Riegl ressalta o valor que supõe ser o mais democrático: o de antiguidade, por ser aquele que qualquer pessoa é 
capaz de apreender devido a suas características não modernas. Ele afirma que o valor é capaz de tocar o sentimento; é aquele em que as pessoas são capazes de reconhecer a trajetória natural da vida e a atuação das leis da natureza.

"Esta vantagem do valor de antiguidade se destaca de um modo especialmente claro frente ao valor histórico, que descansa sobre uma base cientifica e só se pode conseguir indiretamente por meio da reflexão intelectual, enquanto que o valor de antiguidade se manifesta imediatamente ao que o contempla por meio da percepção sensorial mais superficial (a ótica), e pode, portanto falar de modo direto ao sentimento." (RIEGL, 1999, p.55)

Segundo Choay, ao demonstrar o caráter de "culto" que o monumento poderia adquirir e ao estipular que $\mathrm{o}$ valor de antiguidade seria $\mathrm{o}$ predileto das massas, Riegl antecipou questões pertinentes ao Patrimônio Histórico como o temos hoje, na era da indústria cultural: o fervor pelo antigo, a construção de hotéis e toda infra-estrutura pertinente ao turismo cultural, e aí podemos incluir as práticas de restauração voltadas para a reutilização mercadológica de bens patrimoniais. No entanto, Fonseca alerta para o fato de que Riegl não foi capaz de vislumbrar os problemas que a mercantilização dos bens culturais causaria fazendose necessário, hoje, que fosse acrescentado o "valor de troca" na dinâmica dos valores atribuídos aos bens culturais.

Além disso, Riegl não se aprofundou sobre as práticas de restauração em si e nem explorou questões pertinentes à cidade como um todo, premissas que se tornariam importantes mediante acontecimentos como as reformas urbanas modernistas encabeçadas pelo barão de Haussmann, em Paris e a $2^{a}$. Guerra Mundial.

A partir desses acontecimentos tornou-se necessária uma outra postura com relação ao patrimônio e principalmente, uma efetiva metodologia de 
restauro dos monumentos, como a desenvolvida por Cesare Brandi. Segundo Kühl (2007), até meados do século XX não se levava em conta as contribuições da Estética nas teorias de restauração, no entanto, essa necessidade veio a tona com a devastação provocada pela $2^{\mathrm{a}}$. Guerra Mundial.

Nesse momento, eram necessárias abordagens que ultrapassassem o caráter apenas documental da obra e que abarcassem também o aspecto figurativo.

"Passa-se a encarar o restauro como ato histórico-crítico, que deve respeitar as várias fases por que passou a obra e que preserva a pátina, ou seja, conserva as marcas da própria translação da obra no tempo, mas com consciência também de qualquer ação sobre a obra intervém em sua realidade figurativa (pois mesmo uma limpeza que remova a sujeira, mas preserve a pátina o faz)." (KÜHL, 2007, p. 9)

Brandi organiza uma metodologia científica para o processo de restauração principalmente em função das obras de arte italianas danificadas pelos bombardeios da Guerra. Como no exemplo citado por Kühl sobre a restauração dos afrescos da Capela Mazzatosta, na Igreja de S. Maria della Verità em Viterbo, onde os afrescos foram transformados em 20.000 pequenos fragmentos e foi necessária uma metodologia efetivamente crítica, principalmente para o tratamento das lacunas de algumas pinturas.

Nesses casos, como em tantos outros do gênero recorrentes na Itália pós-guerra, a busca da unidade imagética da obra era fundamental para a sua compreensão, o que culminou com o aprimoramento metodológico a partir da Estética, como descrito por Brandi na Teoria da Restauração, capítulo 3 - A unidade potencial da obra de arte. 
Assim, Brandi e o Instituto Central de Restauração (ICR) concentraram suas atividades na restauração de obras de arte e por isso, na teoria brandiana, os monumentos são tratados como tal. Isso, porém, não invalida o postulado da Teoria da Restauração sobre a dúplice polaridade estética e histórica definida por ele.

Kühl afirma que, atualmente, houve um alargamento nessa denominação dada as obras passando a serem chamadas de "bens culturais" e não mais de "obras de arte", como nas formulações de Brandi: “(..) mesmo não sendo 'obras de arte', com o tempo adquiriram significado cultural e que possuem valor documental e uma configuração.”

Além do aspecto estético, Riegl também se omitiu sobre a preservação de cidades históricas, o chamado patrimônio urbano, desenvolvido com maior clareza por Gustavo Giovannoni, que tratava a cidade como monumento histórico e tecido vivo, concomitantemente.

"A teoria de Giovannoni antecipa, de forma simultaneamente mais simples e mais complexa, as diversas políticas das "áreas protegidas" que foram desenvolvidas e aplicadas na Europa a partir de 1960. Contém, igualmente, em germe, seus paradoxos e dificuldades". (CHOAY, 2001, p. 203)

Segundo Choay, a doutrina de Giovannoni se baseava em três princípios básicos:

1. Os fragmentos urbanos deveriam ser tratados sob o ponto de vista técnico e humano, ou seja, deveriam ser inseridos num plano diretor que tratasse a cidade nas suas esferas local, regional e territorial e que englobasse o aspecto simbólico daquele espaço. 
2. Além disso, Giovannoni insere o conceito de "ambiência", ou seja, relaciona o bem ao entorno em que está inserido. "É por isso que, na maioria dos casos, isolar ou 'destacar' um monumento é o mesmo que mutilá-lo. O entorno do monumento mantém com ele uma relação essencial" (CHOAY, 2001, p. 201)

3. Por fim, estipula que os conjuntos urbanos devem ser tratados relativamente a sua escala para preservar suas relações originais. "Admite-se, portanto, uma margem de intervenção limitada pelo respeito ao 'ambiente', esse espírito (histórico) dos lugares, materializado em configurações espaciais." (CHOAY, 2001, p. 201)

Posteriormente a Giovannoni, as Cartas de Washington de 1986 e de 1987 também trataram da salvaguarda das Cidades Históricas e prescreveram não só os elementos a serem preservados, mas também a participação popular atuando no processo de preservação, assim como alertam o Poder Público sobre cuidados na realização de intervenções na malha urbana histórica, principalmente em relação ao traçado viário.

O pensamento de Giovannoni suscita discussões sobre a possibilidade de preservação de áreas históricas sem o tombamento, através de regulamentações acerca do uso e ocupação do solo. Apesar desse modelo de preservação ser uma das preocupações desta dissertação - desenvolvida na proposta - Conclusão, o objetivo central do trabalho é compreender de que maneira ocorre a eleição dessas áreas em detrimento de outras, considerando a possível existência de mecanismos de dominação cultural incorporados ao processo de seleção dos bens patrimoniais. A escolha da obra de Alöis Riegl como norteadora do trabalho ocorre, portanto, em função do caráter precursor do pensamento riegliano 
ao tratar a arte e o monumento como um objeto social envolvido por um contexto histórico.

Riegl segue, assim, inovador para sua época e pertinente à contemporaneidade no que diz respeito a legitimar, culturalmente, os processos de preservação dos monumentos. Como ressalta Fonseca, foram antevistas no trabalho de Riegl muitas conquistas e evoluções na questão patrimonial obtidas contemporaneamente:

"Essa profecia foi plenamente concretizada tanto na evolução das ciências históricas, com a crítica à história factual, o surgimento da história das mentalidades e do conceito de longa duração, a ampliação da noção de documento e o desenvolvimento da historiografia, quanto nas políticas de preservação, com a ampliação do conceito de patrimônio". (FONSECA, 2005, p. 67)

Fonseca afirma que Riegl utiliza a mobilização social como instrumento para a preservação, sem que essa mobilização passe pela persuasão ideológica e, por esse motivo, ele não faz menção a um suposto valor nacional e nem utiliza o termo "patrimônio". Segundo a autora, Riegl se vale de uma postura humanista, inspirada em ideais iluministas, buscando valores éticos e estéticos para justificar a preservação do bem. Além disso, Fonseca ressalta que numa perspectiva política, essa demanda social para legitimar o patrimônio "tem sido traduzida, nas últimas décadas, na noção de direitos culturais.” (FONSECA, 2005, p. 70)

Segundo Fonseca, os direitos culturais são derivados da noção de cidadania que envolve também: os direitos políticos - fundados no valor de liberdade; direitos sociais e econômicos - fundados no valor de igualdade (no qual os direitos culturais também se fundamentam) e direitos de solidariedade - fundados no valor de fraternidade. Essa diversificação dos direitos humanos se dá em relação 
à crescente particularização dos sujeitos sociais que deixaram de ser caracterizados apenas por sua nacionalidade ou classe social e passaram a ser representados por outras categorias como sexo, etnia, religião, cultura, etc.

A autora afirma que a expressão "direitos culturais" surgiu pela primeira vez na Constituição Soviética de 1918, sendo reconhecida internacionalmente somente em 1948, na Declaração Universal dos Direitos Humanos, da ONU:

"Artigo XXII - Toda pessoa, como membro da sociedade, tem direito à segurança social e à realização, pelo esforço nacional, pela cooperação internacional e de acordo com a organização e recursos de cada Estado, dos direitos econômicos, sociais e culturais indispensáveis à sua dignidade e ao livre desenvolvimento da sua personalidade. ${ }^{\text {,A2 }}$

Fonseca ainda levanta a hipótese de que os direitos culturais só ganharam a atribuição de direitos humanos devido a algumas condições provocadas pela $2^{\mathrm{a}}$. Guerra Mundial, dentre elas o que a autora chama de "antropologização" do conceito de cultura, ou seja, passaram a ser consideradas cultura atividades e manifestações de qualquer grupo humano. A partir dessa conscientização, tornou-se necessário defender culturas de minorias, possivelmente ameaçadas por culturas mais poderosas.

Nesse sentido, a autora alerta para o fato de que em países que se originaram de colônias européias marcadas pela escravidão, a noção de cultura foi prejudicada tanto em relação à produção de classes populares, como também pelo fato de que era considerada cultura apenas aquela importada da metrópole

\footnotetext{
${ }^{42}$ Declaração Universal dos Direitos Humanos, adotada e proclamada pela resolução 217 A (III), da Assembléia Geral das Nações Unidas, em 10 de dezembro de 1948. Disponível em: $<$ http://www.mi.gov.br/sedh/ct/legis intern/ddh bib inter universal.htm> acesso em: novembro de 2006
} 
européia. Sendo assim, a noção de direitos culturais é tão restrita de sentido como a própria noção de cultura:

"E se, como observa Eunice R. Durham, nos países sem uma tradição democrática consolidada 'são os movimentos sociais que operam a transformação de necessidades e carências em direitos', o que pode ser visto 'como um amplo processo de revisão e redefinição do espaço da cidadania' (1984, p. 29), no caso dos direitos culturais, pelo menos no Brasil, essas necessidades e carências em grande parte ainda dependem, para serem formuladas enquanto direitos culturais, da mediação de agentes estatais." (FONSECA, 2005, p. 74)

No Brasil, os direitos culturais foram incorporados, pela primeira vez,

na Constituição Brasileira de 1988, na Seção II - Da Cultura, onde o Estado garante,

nos incisos, a proteção, a valorização e o acesso à cultura:

"Art. 215 - O Estado garantirá a todos o pleno exercício dos direitos culturais e acesso às fontes da cultura nacional, e apoiará e incentivará a valorização e a difusão das manifestações culturais.

$\S 1^{\circ}$ - O Estado protegerá as manifestações das culturas populares, indígenas e afro-brasileiras, e das de outros grupos participantes do processo civilizatório nacional.

$\S 2^{\circ}$ - A lei disporá sobre a fixação de datas comemorativas de alta significação para os diferentes segmentos étnicos nacionais.

$\S 3^{\circ}$ A lei estabelecerá o Plano Nacional de Cultura, de duração plurianual, visando ao desenvolvimento cultural do País e à integração das ações do poder público que conduzem à: (Incluído pela Emenda Constitucional $n^{\circ}$ 48, de 2005)

I defesa e valorização do patrimônio cultural brasileiro; (Incluído pela Emenda Constitucional $n^{\circ} 48$, de 2005)

II produção, promoção e difusão de bens culturais; (Incluído pela Emenda Constitucional $n^{\circ} 48$, de 2005)

III formação de pessoal qualificado para a gestão da cultura em suas múltiplas dimensões; (Incluído pela Emenda Constitucional n 48, de 2005)

IV democratização do acesso aos bens de cultura; (Incluído pela Emenda Constitucional $n^{\circ} 48$, de 2005)

$\checkmark$ valorização da diversidade étnica e regional. (Incluído pela Emenda Constitucional $n^{\circ} 48$, de 2005)" ${ }^{43}$

43 Constituição da República Federativa do Brasil de 1988. Disponível em: https://www.planalto.gov.br/ccivil 03/Constituicao/Constitui\%C3\%A7ao.htm. Acesso em: dezembro de 2006. 
Como alerta Fonseca, essa temática não foi incorporada às políticas públicas brasileiras por não ser um campo propício para afirmação e exercício do poder e "justifica-se" o desfalque de programas de partido e plataformas de eleição pela teoria de que há necessidades mais importantes a serem atendidas. No entanto, a mesma autora verifica que há um interesse cada vez maior de governos municipais e estaduais pela demanda cultural.

Bobbio (1992 apud Fonseca, 2005, p. 72) diz que o maior problema atual não está na fundamentação dos direitos humanos e sim na garantia do seu cumprimento. No caso dos direitos culturais, muito mais do que seu reconhecimento jurídico faz-se necessário que todos os cidadãos tenham acesso a esses direitos, sendo imprescindível, para isso, o empenho do Estado e a mobilização da opinião publica.

No entanto, como verificaremos a seguir, muitas vezes a cultura, mais especificamente o patrimônio, funciona como instrumento ideológico de afirmação de poder por parte de uma cultura dominante, ou por um ou mais grupos hierarquicamente superiores na máquina estatal, para quem a democratização do patrimônio (viabilização da proteção, acesso e recepção do bem) oferece riscos a manutenção da sua posição dominante.

\section{III.3. Dominação cultural: o poder do patrimônio.}

Segundo a Constituição Brasileira de 1988, no seu artigo 216 da Seção II - Da Cultura, os bens que sejam "portadores de referência à identidade, à ação, à memória dos diferentes grupos formadores da sociedade brasileira”, sejam 
eles materiais ou imateriais, constituem o patrimônio cultural do Brasil, nos quais se incluem:

"I - as formas de expressão;

II - os modos de criar, fazer e viver;

III - as criações científicas, artísticas e tecnológicas;

IV - as obras, objetos, documentos, edificações e demais espaços destinados às manifestações artístico-culturais;

$V$ - os conjuntos urbanos e sítios de valor histórico, paisagístico, artístico, arqueológico, paleontológico, ecológico e científico." 44

A partir disso, levanta-se uma hipótese sobre as dimensões atribuídas ao que se denomina patrimônio:

1. Dimensão física - que são os objetos em si, no caso do patrimônio material; ou a manifestação pelo meio físico do patrimônio imaterial.

2. Dimensão social - que é aquilo que o patrimônio representa, comunica ou constrói na sociedade, ou seja, a relação entre os atores sociais e sua atuação na dimensão física. Aqui podemos incluir a memória e as construções de identidades coletivas e individuais.

Segundo Fonseca (2005), tais maneiras de apropriação do patrimônio são reguladas por duas noções articuladas sobre as categorias de tempo e espaço: a noção de história e a de arte, as quais estão vinculadas, respectivamente, à reelaboração do passado e à fruição estética presente.

44 Constituição da República Federativa do Brasil de 1988. Disponível em: https://www.planalto.gov.br/ccivil 03/Constituicao/Constitui\%C3\%A7ao.htm. Acesso em: dezembro de 2006. 
Tanto Alöis Riegl quanto Cesare Brandi nortearam suas idéias a partir dessa distinção entre dois momentos ou, como denomina Brandi, em relação a essa dúplice historicidade. Em Riegl, esse jogo entre momentos históricos se dá tanto pela oposição dos valores, que operam nas duas historicidades, quanto no próprio conceito de Kunstwollen, como visto anteriormente. Já Brandi define essa relação da seguinte forma:

"(...) aquela que coincide com o ato de sua formulação, o ato da criação e se refere, portanto, a um artista, a um tempo e a um lugar, e uma segunda historicidade, que provem do fato de insistir no presente de uma consciência, e portanto, uma historicidade que se refere ao tempo e ao lugar em que está naquele momento." (BRANDI, 2004, p.32)

Dessas noções decorre a dinâmica morfológica da cidade. Os espaços de permanência e de transformação são dados a partir da reelaboração da memória pela própria comunidade e, na medida em que esses espaços representam o imaginário coletivo, são preservados naturalmente por uma espécie de acordo entre os cidadãos, mas não estão livres de transformações. Já no caso do tombamento tal permanência é garantida pelo Estado, por serem reconhecidos como detentores de valores importantes para determinada comunidade.

Podemos, então, atribuir ao patrimônio o sentido de representação da sociedade no meio físico, sendo necessário, porém, frisar que além de representá-la, o patrimônio também comunica à sociedade conteúdos fundamentais para constituição de identidades. Argan situa na Renascença a seguinte transformação (ARGAN, 1998, p.235): “(...) a cidade deixa de ser lugar de abrigo, proteção, refúgio e torna-se aparato de comunicação; comunicação no sentido de deslocamento e de relação, mas também no sentido de transmissão de determinados conteúdos urbanos". Compreende-se que mais do que representar 
poderes ou valores, a arquitetura passa a comunicá-los e a denunciar as relações econômicas da sociedade através das construções.

Essa questão da diferenciação social no espaço urbano configura, através da história das cidades, paisagens hierarquizadas por escalas de prestígio. Talvez essa segregação tenha sido agravada devido aos planos modernizadores do final do século XIX e início do século XX, que delimitaram os espaços da cidade e buscaram uma imagem de progresso da qual a classe operária não fazia parte. $\mathrm{O}$ que mais impressiona, no entanto, é que a segregação social através dos espaços públicos e da arquitetura é cada vez mais legitimada pelos instrumentos organizadores do espaço urbano e, consequentemente, pelo Estado. Rolnik (2003) e Lanna (1996) demonstram isso ao tratarem da questão da segregação e exclusão social na formação do espaço público, seja pelo viés da história da legislação urbana em São Paulo (Rolnik), seja pela transição do trabalho escravo para o livre e a conseqüente configuração espacial desse processo (Lanna).

Em se tratando de bens eleitos como representativos de uma comunidade, o patrimônio pode funcionar como um instrumento que acentue e evidencie tais relações de exclusão e dominação cultural, se não forem feitas reflexões pertinentes ao processo de preservação da memória, como a recepção e a eleição dessas materialidades.

Como em qualquer apropriação social, a recepção do patrimônio é ativa e acontece de maneiras variadas de acordo com o momento histórico e o grupo envolvido. Ativa no sentido da sua reelaboração pelo receptor no momento da fruição estética, como demonstra a citação de Chartier (1988 apud FONSECA, 2005, p.43): todo receptor é, na verdade, um produtor de sentido. Essa afirmação nos leva 
a deduzir que são possíveis abordagens e apropriações diferenciadas para um mesmo objeto, da mesma forma como nos sugere possíveis limites culturais que venham a impossibilitar a fruição e, por conseqüência, a democratização do patrimônio, haja vista a complexidade do processo - muito maior do que viabilizar o acesso ao bem. Nesse sentido, Canclini (2003) alerta para o fato de que os bens patrimoniais apenas pareçam formalmente ser de todos mesmo que estejam disponíveis para utilização coletiva e, no entanto, não pertencem realmente a todos justamente devido à existência de uma proporcionalidade, reconhecida pelo autor, entre "capacidade de apropriação" do que ele chama de capital cultural transmitido por instituições de memória e a escala econômica e educacional do individuo.

A atribuição de alguns bens como patrimoniais e merecedores de proteção legal do Estado surge no final do século XVIII, durante a Revolução Francesa, pressupondo um consenso sobre o valor atribuído a determinados bens que representassem a nação, idéia surgida na mesma época. Esses bens eram escolhidos de forma a legitimar uma comunidade e reforçar o sentimento de pertencimento dos indivíduos a ela relacionados. Chagas (2003) questiona essa noção de "pertencimento" - que segundo ele é ação política que faz associar e até mesmo confundir pertencimento com identidade, com o intuito de 'transformar 'uma' representação do nacional 'na' marca expressiva do nacional, 'uma representação da memória 'em' memória, como se o nacional e a memória pudessem ser enquadrados e fixados." (CHAGAS, 2003, p.141)

Segundo Chagas, é essa ideologia de representação nacional que legitima as ações das instituições responsáveis pela proteção e divulgação do patrimônio. A partir daí, concluímos que frequentemente cria-se uma relação dialética entre a finalidade patrimonial inicial, defendida por essas instituições, e sua 
efetiva apropriação por grupos representativos de minorias étnicas ou sociais. Isso porque, se considerarmos que não é concedida importância merecedora ao processo de fruição dessa cultura por todos os cidadãos, que ela supostamente representa, a nação se restringiria a alguns indivíduos apenas.

No entanto, há que se considerar que as exclusões não se limitam à recepção do patrimônio, mas operam, principalmente, na constituição deste. O processo de seleção de bens, por muitas vezes, privilegia monumentos da cultura dominante o que dificulta ainda mais a identificação dos indivíduos com os símbolos que deveriam legitimar sua presença na sociedade. Aqui, nos aproximamos do pensamento de Canclini (2003) quando ele afirma que algumas representações do nacional correspondem mais a um espetáculo de legitimação política do que as relações da sociedade.

Quando se protege um bem também está sendo protegida a cultura incluindo as práticas sociais por ele representadas, o que acarreta questionamentos sobre o papel do Estado na formação de um patrimônio nacional tendo em vista a pluralidade cultural e as múltiplas memórias coletivas que constituem uma nação.

Torna-se explicito, então, o principal valor atribuído ao bem que deva justificar seu reconhecimento como patrimônio e sua proteção legal: o valor cultural. A cultura, nesse momento, deve ser entendida como aquilo no qual se reconhece a identidade de uma comunidade, ou seja, elementos que em suas particularidades indiquem a origem daquele determinado grupo, nas suas maneiras de produção, apropriação e reelaboração do meio.

Apesar de que os depositários de uma cultura são o fundo que agrega valor ao bem e a cidade ser composta por coletividades múltiplas e 
fragmentadas, há que nos atermos ao fato de que preservação envolve seletividade entre o conservar e o demolir, atividade essa exercida por determinados agentes sujeitos a conflitos de interesses. Essa relação de poder acaba por deixar o valor cultural e a polifonia (CANEVACCI, 1993) de que a cidade é composta de lado, em função de conflitos externos à questão patrimonial.

Segundo Fonseca (2005), a ideologia de nacionalismo que, durante dois séculos, sustentou as políticas estatais do patrimônio está sendo substituída pela idéia de "direitos culturais", vista como uma nova maneira de legitimar tais políticas. Talvez nessa afirmação esteja verdadeiramente explícito todo o poder inerente à questão patrimonial usado como instrumento para construção de uma identidade única, proveniente de uma determinada maneira de apropriação do território por uma determinada cultura, apesar da Unesco, já na década de 40 ter levantado a questão antropológica da cultura e o patrimônio ter-se vinculado à diversidade cultural.

Como demonstra Regina Abreu (2003), Lévi-Strauss já apontava a idéia de que no interior do mesmo país existiam culturas diversas e plurais e que cada nação comportaria culturas e subculturas. No âmbito nacional, essa noção de que há outros grupos e outras materialidades culturais a serem reconhecidas como parte integrante das possíveis identidades, ainda caminha para uma presença maior nas políticas preservacionistas dos órgãos responsáveis.

\section{III.4. A questão cultural nos processos de reapropriação territorial.}

Como podemos verificar, muitas vezes a monumentalização de algumas áreas produzida pelo discurso oficial consagra determinadas culturas com base na recriação de processos do que seria a memória nacional. A construção 
desse imaginário por vezes está vinculada a estratégias de mercadorização do território devido a pressões dos agentes imobiliários.

Agindo dessa forma, o Poder Público e os órgãos competentes pela preservação contribuem para que a identidade e a memória popular instaladas no meio físico através das apropriações cotidianas sejam abandonadas e novas identidades impostas, favorecendo o lucro e a manutenção de uma elite no poder.

Como vimos, o Estado que deveria garantir a efetivação dos direitos humanos atua, muitas vezes, na contramão desse processo, no caso dos direitos culturais.

Assim, pretende-se discutir a necessidade de uma maior vinculação entre os "direitos culturais" dos moradores e usuários da cidade e os processos legislativos, sendo necessário para isso um diálogo entre o que se planeja para a cidade e o que evidentemente é esse espaço para quem o ocupa.

Para a efetivação desse tipo de atuação, é essencial que principalmente os órgãos competentes compreendam que a definição de "bem cultural" não se limita aos aspectos formais da obra, mas inclui suas características sociais e econômicas.

Assim, uma política de preservação do patrimônio deve abarcar muito além da materialidade dos bens móveis e imóveis, pois, como frisa Fonseca (2005), essas coisas são apenas mediadoras dos seus valores culturais pelo interesse público.

"E, se os valores que se pretende preservar - conforme está explícito na abordagem jurídica da questão - são apreendidos na coisa e somente nela, não se pode deixar de levar em consideração o fato óbvio de que os 
significados nela não estão contidos, nem lhe são inerentes: são valores atribuídos em função de determinadas relações entre atores sociais, sendo, portanto, indispensável levar em consideração o processo de produção, de reprodução, de apropriação e de reelaboração desses valores enquanto processo de produção simbólica e enquanto prática social." (FONSECA, 2005, p. 40)

Dessa forma, acredito que sem o diálogo entre planejamento urbano e patrimônio histórico associados à participação popular, os direitos culturais no Brasil se tornam declarações de boas intenções e a legitimação da cidadania no âmbito da cidade, apenas um ideal distante. 


\section{CAPÍTULO IV}

Desqualificação urbana e políticas neoliberais: o caso da Avenida Conselheiro Nébias

"O (...) discurso [da globalização], que fala da ética, esconde, porém, que a sua é a ética do mercado e não a ética universal do ser humano, pela qual devemos lutar bravamente se optamos, na verdade, por um mundo de

gente."

(PAULO FREIRE) 


\section{IV.1. Introdução.}

Este capítulo traz um panorama do segmento inicial da Avenida Conselheiro Nébias sob seus aspectos morfológicos e socioeconômicos tal qual se apresentam hoje, com o objetivo de afirmar a importância de seus quarteirões como detentores de verdadeiros documentos sobre a moradia em diferentes épocas de Santos. Para isso, traça um perfil da população que habita a área e que vem sendo ameaçada de expulsão desde 1998, data da aprovação do Plano Diretor municipal de Santos.

Como visto nos capítulos anteriores, a materialidade contém um valor simbólico com conseqüências práticas nas relações sociais, que pode ser acentuado em áreas antigas ou históricas, no caso da cidade. Dessa forma, entende-se que novas intervenções devam considerar a cidade como objeto socialmente construído, ao qual se vinculam não só o atendimento de necessidades ou interesses, mas também de afetos e identidades sociais, sendo suas áreas historicamente mais sedimentadas referenciais e fontes de conhecimento em geral e, sobretudo, auto-conhecimento dos diferentes grupos, camadas ou classes que a habitam .

Portanto, o presente capítulo aborda o modelo de intervenção proposto pela municipalidade santista através do seu Plano Diretor visando compreender e discutir os objetivos e as conseqüências das suas orientações para a Avenida Conselheiro Nébias, mostrando que ela está ameaçada, dadas estas circunstâncias, pelo fenômeno de gentrificação. Concorre para a discussão um panorama da atual estratégia do planejamento que privilegia a transformação do 
solo urbano em um produto lucrativo e a apropriação cenográfica da cidade, desconsiderando as referências de memória e identidade dos seus habitantes.

\section{IV.2. Aspectos morfológicos e socioeconômicos.}

Atualmente, a Avenida Conselheiro Nébias ainda é o único eixo de ligação direta entre o cais e as praias, desembocando na antiga praia da Barra, atual Boqueirão. Situada exatamente na linha norte-sul, a avenida conecta a porção mais antiga e popular da cidade - os bairros portuários, à orla, sendo esta uma das regiões onde o solo urbano tem maior valor monetário em Santos.

O segmento da avenida estudado nesta dissertação corresponde a sua porção mais antiga e popular, cortando os bairros Vila Nova e Vila Matias e delimitando de um lado o bairro Encruzilhada e de outro o Macuco.

Para que fosse possível traçar o perfil morfológico da área, foi desenvolvido um cadastro dos bens imóveis contendo informações básicas sobre as edificações como: endereço completo, denominação e uso atual do edifício, data da construção e da última reforma, breve descrição da obra, além de foto e um mapa localizando a edificação no lote e na quadra da Avenida Conselheiro Nébias. Devido ao grande número de quadras estudadas - vinte e sete, computando uma média de duzentos e setenta lotes, optou-se por limitar o inventario de cada edificação ${ }^{45}$ ao estudo de fachadas e implantações para uma compreensão básica da sua contribuição para a configuração do espaço urbano.

\footnotetext{
${ }^{45}$ Em um inventário completo, cada edificação seria detalhadamente estudada, não só fachada e implantação, mas também disposição dos cômodos, programa, estrutura, materiais construtivos, etc., além de pesquisa histórica sobre construtores e moradores, dentre outros.
} 


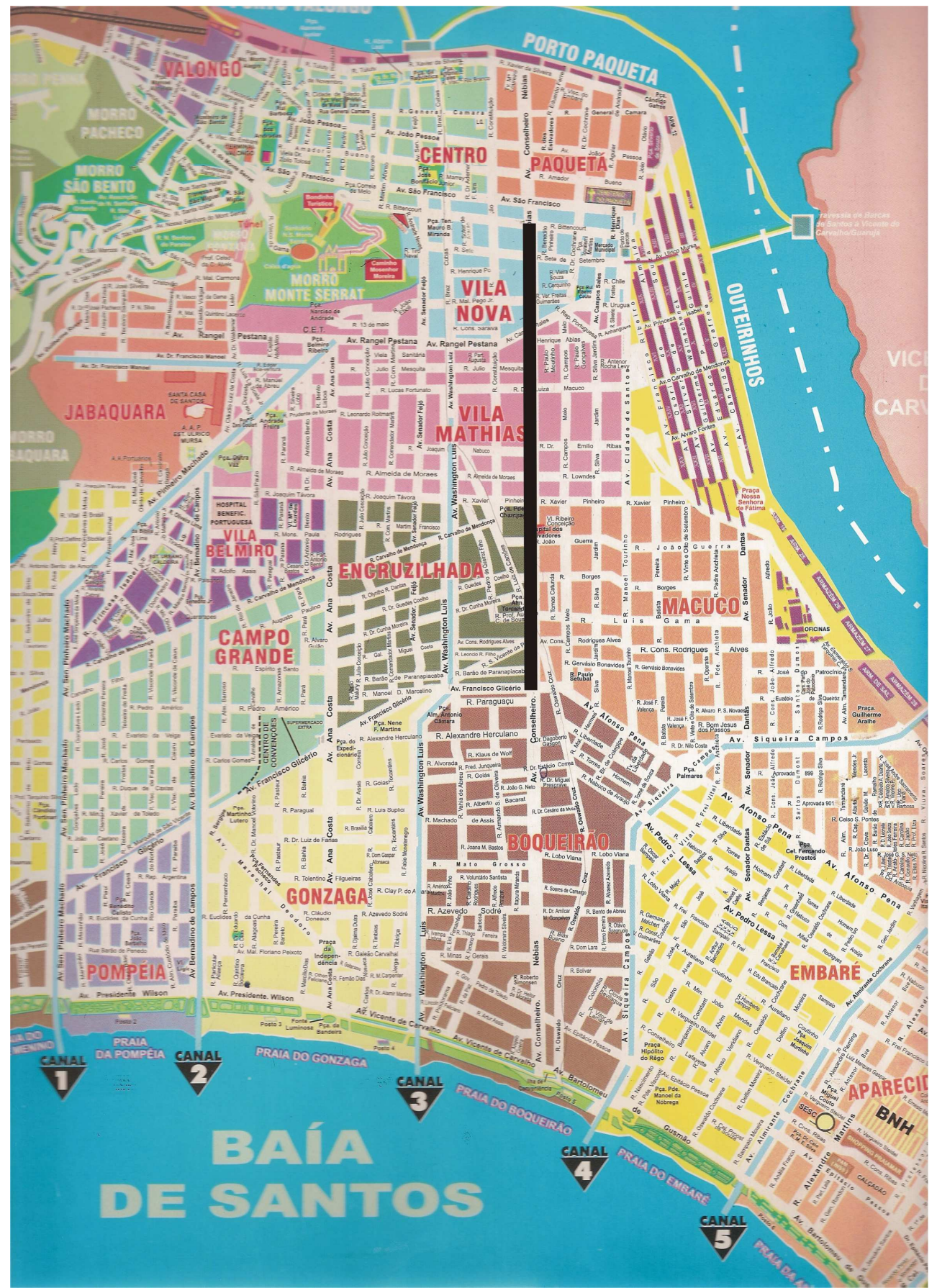

Figura 21: Localização no traçado urbano da Avenida Conselheiro Nébias, com o trecho estudado destacado em negrito, cortando Vila Mathias (em rosa) e Vila Nova (em azul) e delimitando os bairros Macuco (em laranja) e Encruzilhada (em verde). (Fonte: Mapa de Santos, Solen Comunicação e Editora, 2003) 
Completando a metodologia do levantamento, criou-se uma numeração para as quadras de acordo com a visão de quem percorre o trecho escolhido no sentido sul-norte, ou seja, praia-centro, já que é assim que a revalorização urbana ocorre atualmente, e alternando um lado e o outro da avenida, seqüencialmente.

Com as informações obtidas no cadastro, confeccionou-se uma série de mapas que colaboraram para o entendimento do local. São eles: mapa de cronologia construtiva utilizando a data da construção das edificações; mapa de cronologia construtiva com a data da última reforma sofrida; mapa de gabarito de altura no período atual; mapa de uso das edificações no período atual; e, finalmente, mapa da legislação urbanística e da patrimonial às quais a área está submetida (ver Anexo B).

Dessa forma, foi possível constatar que algumas edificações apresentam semelhanças relacionadas mais a concepções de uso dos espaços e capacidade de investimento na construção presentes em diferentes períodos, do que a padrões estilísticos. Portanto, mesmo que tais semelhanças não se enquadrem plenamente em estilo arquitetônico, pelo fato de obedecerem a certas semelhanças espaciais e construtivas, entendemos que as edificações podem ser reunidas em grupos tipológicos (ver Anexo A). Assim, apesar das inúmeras modificações promovidas pelos moradores nas edificações - que algumas vezes dificultam a leitura da fachada, aos grupos podem ser associados tipos como síntese formal.

Os tipos encontrados definem, de modo geral, o perfil morfológico da avenida, composto por edificações baixas, predominando casas de dois pavimentos ou edifícios multifamiliares de três pavimentos sobre pilotis. 
Apresentam poucos elementos decorativos na fachada, com telhados de quatro águas aparentes ou encobertos por platibandas na fachada principal. Em relação ao lote, a grande maioria das edificações está afastada dos seus limites por recuos laterais, frontal e de fundo. Entretanto, no bairro Vila Nova, o mais próximo do porto, são mais freqüentes edificações dispostas no alinhamento da calçada e sem recuos laterais.

O revestimento mais utilizado nas fachadas é a pintura em cores claras, seguido de pastilhas e/ou azulejos - principalmente nas edificações reformadas nas décadas de 80 e 90 do século XX. Nas edificações com porão habitável há ocorrência de pedras como revestimento. Há também a presença de grandes aberturas na fachada tanto das casas como dos prédios (alpendres ou sacadas).

A avenida se destina hoje principalmente ao comércio popular, às pequenas lojas de veículos usados e à habitação popular, além de sediar sindicatos e algumas instituições de ensino. A maioria das edificações construídas no período anterior a 1998 tinha como finalidade inicial a moradia, entretanto foram adaptadas pela classe popular para fins comerciais, ainda que o pavimento superior tenha continuado como residência. Em alguns casos, as casas tiveram seus cômodos alugados, transformando-se em moradias multifamiliares. Já aquelas construídas a partir do final da década de 90 têm como uso e destino de origem o comércio.

Além disso, alguns bens da avenida são tombados e outros se encontram em estudo de tombamento pelo órgão autônomo e deliberativo que cuida do tombamento e da preservação dos bens culturais e naturais no município, o 
CONDEPASA. Os bens tombados pelo Condepasa com nível 01 de proteção, com garantia de sua preservação integral são:

- imóvel situado à Avenida Conselherio Nébias no. 361, no bairro Vila Mathias, Condepasa, livro Tombo 01, inscrição 32, folha 6, proc. 36215/200401, resolução SC 02/2004 de 13/12/2004.

- imóvel situado à Avenida Conselherio Nébias no. 488, no bairro Encruzilhada, edifício onde abriga a "Capitania dos Portos do Estado de São Paulo", Condepasa, livro Tombo 01, inscrição 33, folha 6, proc. 51635/2003-82, resolução SC 01/2005 de 02/06/2005.

- edificação remanescente do "Sistema Coletor de Esgoto Sanitário", idealizado pelo eng. Francisco Saturnino de Brito, localizada na Avenida Conselheiro Nébias esquina com a Rua Campos Sales, bairro Vila Nova, Condepasa, livro Tombo 01, inscrição 33, folha 6, proc. 93921/1999-30, resolução SC 03/2004 de 13/12/2004.

- canal 1 de drenagem, no trecho da Avenida Campos Salles, os passeios que ladeiam o canal e os elementos do projeto original para circulação e proteção de pedestres, como pontes, amuradas, guarda corpos e demais componentes operacionais do sistema, Condephaat, resolução SC-23, de 16/06/2006, Condepasa, livro Tombo 01, inscrição 42, proc. 114456/2007-13, resolução SC 02/2007 de 12/11/2007. ${ }^{46}$

A despeito do tombamento, em todo o segmento estudado existe apenas a regulamentação de área envoltória para um dos bens inscritos com nível

\footnotetext{
${ }^{46}$ São tombados todos os canais de drenagem situados no município de Santos, entretanto apenas o canal 1, no trecho da Avenida Campos Salles, corta o segmento estudado.
} 
01 de proteção: o Sistema Coletor de Esgoto Sanitário. Projeto de Saturnino de Brito gravado com nível 01 de proteção, o bem possui área envoltória que protege pelos níveis 3 e 2, respectivamente, as edificações localizadas nos números 221/223 da mesma quadra e 219 na quadra seguinte.

A área que envolve um bem tombado tem a finalidade de proteger a boa leitura desse imóvel, restringindo construções no seu entorno que possam interferir no cone visual e na ambiência, por um raio pré-determinado pelo órgão responsável pelo tombamento.

Com relação aos outros bens, a especificação de área envoltória não existe, nem garantida pelo órgão responsável pelo patrimônio santista, muito menos pelo pela legislação urbana. Dessa forma, entende-se que os outros imóveis tombados na área, como por exemplo, a Capitania dos Portos, ficarão ilhados num futuro próximo quando o incentivo municipal à verticalização e ao adensamento se concretizarem.

Além desses, outros bens estão em estudo de tombamento pelo órgão municipal responsável. São eles:

- Edifício do Corpo de Bombeiros, localizado no número 184; processo no. 36195/2004-97.

- Edifício da Clínica São Miguel Arcanjo, localizada no número 188/190; processo no. 36206/2004-10.

- Edifício do $4^{\circ}$. Distrito Policial, localizado no número 258; processo no. $36211 / 2004-41$. 
- Edifício sede da instituição Gota de Leite, localizado no número 388; processo no. 36239/2004-61.

O edifício da residência de Sebastião Ferreira, localizado no número 310 da avenida, originário do início do século $X X$, cujas paredes internas eram revestidas por pinturas murais, esteve em estudo de tombamento, porém, devido ao seu estado atual de degradação, o processo não consta mais na relação desses estudos no Condepasa.

$\mathrm{Na}$ verdade, independente do reconhecimento legal, alguns quarteirões da Avenida Conselheiro Nébias se configuram em documentos que retratam as diversas formas de moradia em Santos. Isso porque a avenida é composta por edificações de vários períodos, desde casarões originários da virada do século XIX para o XX, passando por casas com alpendre e porão habitável da década de 20 , edificações no alinhamento da calçada da década de 30 , geminadas da década de 40, sobrados da década de 50 e 60, edificações multifamiliares também de 50 e 60, edificações térreas da década de 70 (nas quais prevalece a horizontalidade), até as construções dos anos 90 e 2000, descontextualizadas do restante quer pela forma e/ou monumentalidade, quer pelos revestimentos utilizados. Somam-se a isso, todas as adaptações e transformações desses espaços para responder as necessidades e anseios das gerações de usuários e moradores que ocuparam tais edificações desde sua origem até a atualidade.

Atualmente, a população que habita a avenida é composta principalmente por jovens e adultos, de idade média entre 15 a 29 anos, com renda mensal do responsável pelo domicílio variando entre 1 1/2 a 10 salários mínimos. Essa grande variação da renda ocorre em função da proximidade do porto e do 
gênero do responsável pelo domicílio, pois a população do bairro Vila Nova, próximo ao cais, inclui uma grande parcela de mulheres responsáveis pelo rendimento familiar, cuja renda mensal é menor do que a encontrada nos outros bairros. Além disso, é também na Vila Nova que a grande maioria da população vive em cômodos, enquanto que mais próximo da linha férrea o número de moradores de cômodos decresce e aumenta o percentual de casas e apartamentos próprios, proporcionalmente ao crescimento da renda familiar ${ }^{47}$.

Portanto, é possível considerar a avenida como um vestígio do processo de ocupação do território santista diante do cenário histórico-econômico nacional. Além disso, ela não só representa materialmente conflitos políticos, ideológicos e estéticos de vários períodos, como também é referência de uma população heterogênea e diversificada que nela reconhece sua história, reelabora sua memória e afirma sua identidade.

"Os marcos culturais de pedra e cal, antigas estruturas arquitetônicas em paisagens urbanas, (...) celebram realizações políticas e estéticas, sempre sujeitas à reelaboração pela cultura vernacular, conseguida na luta pela legitimação de interesses práticos, valores estéticos e visões de mundo. Eles são, além disso, resultado de processos que transformam 'espaços' em 'lugares', isto é, em sítios habitados por pessoas que vivem de formas determinadas e que os consideram como algo que lhes pertence ou no mínimo Ihes dizem respeito (...). Projetos, sonhos, ambição, mais do que a acumulação por inércia do legado de antepassados, constituem a principal matéria social que (se pode) reconhecer nas cicatrizes e fraturas da paisagem urbana." (ARANTES, 1997, p. 288)

\footnotetext{
${ }^{47}$ Sobre o perfil socioeconômico da área, ver o levantamento do IBGE sobre rendimento mensal dos moradores, média de moradores por domicílio, tipos de domicílio e faixa etária e gênero da população residente nos bairros que englobam a Avenida Conselheiro Nébias no Anexo C. É preciso alertar, porém, que o levantamento é uma média geral dos bairros e não especificamente dos lotes estudados nessa dissertação, que são somente os voltados para a avenida.
} 


\section{IV.3. Gestão urbana frente à política neoliberal.}

A valoração dos sítios urbanos como documento foi incorporada a postura do IPHAN a partir da década de $1980^{48}$ e, segundo Motta (2000), tem como marco dessa transição o parecer sobre o tombamento de Laguna, redigido pelo arquiteto Luis Fernando Franco em 1984, editado em 1995 no Caderno de Documentos do IPHAN:

"Em sua dimensão estritamente arquitetônica, o patrimônio construído do centro histórico de Laguna não apresenta as características de excepcionalidade normalmente adotadas como critério para decidir sobre a oportunidade do tombamento. Sob este ponto de vista, não saberíamos eleger outra edificação que atenda individualmente àquele critério, além da Casa de Câmara e Cadeia, tombada em 1953 pelo então Serviço do Patrimônio Histórico e Artístico Nacional. Cremos, não obstante, tratar-se de documento precioso da história urbana do país, menos como sede de acontecimentos notáveis e embora estes tenham sido ali assinalados, do que pela escolha criteriosa do sítio; pelo papel que o povoado pôde desempenhar, em virtude de sua localização, no processo de expansão das fronteiras meridionais; e, sobretudo, pela forma urbana assumida afinal como precipitação espacial dos dois processos precedentes." (FRANCO apud MOTTA, 2000, p. 267)

A partir daí, os bens passaram a ser considerados em virtude da sua capacidade de representar vestígios do modo de ocupação do território, possibilitando diversas leituras a partir de sua configuração espacial enquanto referenciais de identidade, independentemente de critérios estéticos. Além disso, passou-se a dar valor ao conhecimento da forma dos objetos como sinais culturais que documentam a trajetória das sociedades locais - demonstrando suas condições de produção desses bens, tal como apresentado pelo mesmo parecerista do

\footnotetext{
${ }^{48}$ Inicialmente, os bens eram reconhecidos como patrimônio em função da sua representatividade da unidade nacional (FONSECA, 2005).
} 
tombamento de Laguna, num seminário realizado pelo IPHAN em 1989, reproduzido em 1998 na edição do "Manual do método de inventário - sítios urbanos tombados":

"Implícita na noção de documento está a valorização de uma linguagem própria do sítio urbano - que é a linguagem da forma - e é nela que encontramos expressão e significados. Os homens socialmente organizados moldam os materiais, dando a eles uma forma que se constitui numa linguagem, podendo ser lida, interpretada e entendida. É importante lembrar que a noção de forma aqui referida não se limita àquela que representa um estilo ou uma estética, mas àquela que expressa toda a série de operações que caracteriza a vida do homem no seu modo de estar no mundo. Isso inclui o traçado urbano, as parcelas de subdivisão dos lotes, a organização dos espaços de moradia, os volumes edificados, detalhes de ornamentação etc. A forma é o resultado dos materiais e do território natural moldados diante das possibilidades e limites dos homens ao se apropriarem de um espaço e de estruturas preexistentes ao longo do tempo." (IPHAN apud MOTTA, 2000, p. 268)

Muito embora a noção de cidade-documento tenha continuidade ainda hoje nas atuações do IPHAN e de órgãos estaduais e municipais de proteção ao patrimônio, a aplicação dessa perspectiva é enfraquecida pela política neoliberal instaurada durante a década de 90 no governo federal ${ }^{49}$ seguindo o receituário do Consenso de Washington ${ }^{50}$.

A soberania do mercado auto-regulável nas relações econômicas implicou não só na preparação do patrimônio e da cultura de modo geral para o

\footnotetext{
49 Fernando Henrique Cardoso (1994-2002) é considerado, por muitos autores, como o responsável pela consolidação do ajuste neoliberal nas políticas brasileiras, assim como Mario Covas (1995-2001), eleito pelo mesmo partido, no governo do estado de São Paulo.

${ }^{50}$ Convocados pelo Institute for International Economics em 1989, com o objetivo de avaliarem as reformas econômicas em curso nos países da América Latina, reuniram-se em Washington economistas latinoamericanos de perfil liberal, representantes do Fundo Monetário Internacional (FMI), Banco Mundial e Banco Interamericano de Desenvolvimento (BID) e representantes do governo norte-americano. As conclusões do encontro foram compiladas em dez pontos pelo economista inglês John Willianson que as denominou de “Consenso de Washington” (NEGRÃO, 1998).
} 
consumo, como também veio ao encontro das estratégias de planejamento de cidades segundo o modelo catalão, que tinha como principal defensor Jordi Borja.

Esse tipo de planejamento, inspirado em técnicas americanas de gestão empresarial, havia sido aplicado inicialmente em cidades americanas e inglesas, mas foi amplamente difundido após a experiência de Barcelona, no contexto da preparação da cidade para os Jogos Olímpicos de 1992. Suas diretrizes têm como meta a capacitação das cidades a fim de torná-las competitivas internacionalmente através da adoção de medidas de gestão empresarial na administração pública, na tentativa de sua inserção na economia globalizada, sob a alegação de ser esta a única chance de evitar sua decadência, assim como a da própria nação.

Apesar da associação entre a configuração espacial e a acumulação capitalista não constituir um modelo novo, haja vista a cidade modernista, Arantes (2000) demonstra que essa fase do capitalismo transformou a "cidade-máquina-decrescimento", formulada por Molotch, em metodologia de gestão pública.

“(...) a idéia de cidade como 'growth machine' pode ser assim resumida: coalizões de elite centradas na propriedade imobiliária e seus derivados, mais uma legião de profissionais caudatários de um amplo arco de negócios decorrentes das possibilidades econômicas dos lugares, conformam as políticas urbanas à medida que dão livre curso ao seu propósito de expandir a economia local e aumentar a riqueza." (ARANTES, 2000, p. 27)

Com alguns acréscimos e atualizações em tempos neoliberais, o modelo máquina-de-crescimento foi generalizado sob o pretexto da necessidade de "cidades mundiais" adequadas às necessidades, principalmente de investimento e comunicação imediata, do capital transnacional. A cidade passa a ser vista, 
simultaneamente, como empresa e mercadoria, a ponto de ser gerida não mais "like a business", mas antes "for business", ou seja, a gestão urbana é conduzida pelo mercado e a partir de suas expectativas, pontuadas por intervenções do Estado que, ao invés de se afastar, direciona suas ações para os interesses dos capitalistas. Dessa forma, tal parceria remete à participação direta do capital privado nas decisões e execuções de políticas públicas, alterando os espaços a fim de torná-los mais atraentes para o capital altamente nômade. Sob essa perspectiva, as cidades devem se apresentar como produtos capazes de serem vendidos a investidores, turistas e usuários 'solventes' ${ }^{51}$, mesmo que isso signifique forjar uma imagem distintiva ou criar tradições (ARANTES, 2000; HARVEY, 2003; HOBSBAWM, 2006; VAINER, 2000).

Para Jordi Borja, o espaço que diferencia uma cidade das outras, capaz de torná-la diferenciada e competitiva na atração de capitais, é o Centro ao qual aspectos simbólicos e culturais podem ser associados ou formulados por estratégias de marketing - um dos elementos fundamentais para a efetivação do modelo catalão de planejamento, produzindo verdadeiros espetáculos urbanos através da utilização da cultura como principal insumo ${ }^{52}$.

Nesse processo, no qual solo urbano é valorizado pelo upgrading cultural $^{53}$, a atração de usuários solventes se torna diretamente proporcional a

\footnotetext{
${ }^{51}$ Harvey (2003) chama de pessoas do "tipo certo", ou seja, ricas e influentes.

${ }^{52}$ Sharon Zukin demonstrou em vários trabalhos a utilização da cultura como instrumento de regeneração urbana, como no consagrado Loft Living (1989), sobre a mudança urbana de Nova York na década de 70. Isso evidencia que este não é um processo recente, muito menos específico do planejamento estratégico.

${ }^{53}$ Utilizando a expressão cunhada por Arantes (2000).
} 
expulsão dos insolventes, processo mais conhecido como gentrification, palavra da qual se origina o neologismo gentrificação ${ }^{54}$.

"Neoliberal theorists are, however, profoundly suspicious of democracy. Governancy by majority rules is seen as a potential threat to individual rights and constitutional liberties. Democracy is viewed as a luxury, only possible under conditions of relative affluence coupled with a strong middle-class presence to guarantee political stability. Neoliberals therefore tend to favour governance by experts and elites." (HARVEY, 2005, p. 66)

O que de certa maneira já acontecia é agora legitimado pelo Estado neoliberal ao se tornar estratégia de promoção da cidade. E, se tomarmos o caso de áreas históricas, esse processo desconsidera relações de identidade e a atuação do cidadão, que se reconhece naquele espaço, como agente da sua preservação.

Portanto, apesar da riqueza documental, histórica e simbólica da qual a Avenida Conselheiro Nébias é suporte material, as disposições do Plano Diretor Municipal de 1998 apontam para a verticalização da área que, provavelmente, ocorrerá à custa da construção de altos edifícios para abrigar atividades especializadas, sem vínculo com as tradicionais da área. Esse processo certamente induzirá a elevação do preço do solo e a expulsão dos seus moradores e comerciantes locais, além de desvalorizar o patrimônio reconhecido.

Esse processo caracteriza a proposta da municipalidade para renovação da avenida como gentrificação, fruto de um planejamento municipal que parece seguir a risca a cartilha catalã de planejamento estratégico, omitindo em seu

\footnotetext{
${ }^{54} \mathrm{O}$ termo deriva de gentry, baixa nobreza em inglês. Foi usado pela primeira vez por Ruth Glass nos anos 1960 ao examinar o contexto londrino, referindo-se à penetração de bairros populares por classes mais abastadas. No artigo Paisagens urbanas pós-modernas: mapeando cultura e poder (1996), Sharon Zukin denomina esse processo de "enobrecimento".
} 
discurso revitalizacionista e desenvolvimentista - já que se trata de um "Corredor de Desenvolvimento e Renovação Urbana", os verdadeiros beneficiados.

O projeto de preservação do núcleo urbano central de Santos, "Alegra Centro"55, cujo discurso alega que "a revitalização do centro é fundamental para o desenvolvimento econômico e social da cidade", como preconizado por Jordi, confirma a aproximação entre o planejamento municipal santista e o catalão. Vendido como democrático e de caráter social, o projeto do município não traz em nenhum dos sete pontos que resumem sua ação qualquer referência à população local ou ao seu destino após ser retirada dali - conseqüência implícita. Por outro lado, há um forte apelo ao investidor privado, sendo ressaltadas as campanhas de marketing realizadas pela municipalidade, eventos e atrações que terão "a cultura como âncora de atração do público consumidor". Além disso, um Escritório de Revitalização é oferecido para fornecer apoio aos investidores, frisando, no entanto, que a mudança de uso residencial para aqueles estipulados pelo Poder Público é obrigatória para a concessão dos incentivos fiscais.

Nesses projetos, cuja proposta é despertar um certo "patriotismo cívico", algumas áreas são estrategicamente eleitas como patrimoniais em detrimento de outras que, muito embora sejam tão ou mais representativas para um grande número de habitantes, não correspondem à imagem que a municipalidade (leia-se o mercado) pretende sustentar para atrair o capital transnacional.

Entende-se que as intervenções na cidade deveriam ser condicionadas pelo valor dos lugares enquanto referenciais para as pessoas e não dirigidas a um público criado institucionalmente a partir de interesses econômicos.

\footnotetext{
${ }^{55}$ Disponível em: http://www.alegracentro.com.br.
} 
Portanto, diante do reconhecimento de tamanho potencial simbólico da Avenida Conselheiro Nébias, cabe o questionamento feito por Vainer: "o que é que, afinal de contas, se vende quando se põe à venda uma cidade?" (VAINER, 2000, p. 78) - se não o próprio direito à cidade, à democracia e aos valores de cidadania.

"International competition and globalization can be used to discipline movements opposed to the neoliberal agenda within individual states. (...) the liberal (and by extension the neoliberal) utopian project could only ultimately be sustained by resort to authoritarianism. The freedom of the masses would be restricted in favour of the freedoms of the few." (HARVEY, 2005, p. 70) 


\section{CONCLUSÃO}

"Assim como falham as palavras quando querem exprimir qualquer pensamento, assim falham os pensamentos quando querem exprimir qualquer realidade."

(ALBERTO CAEIRO, Assim como) 


\section{V.1. Considerações finais.}

$\mathrm{Na}$ historia moderna, as alterações no modelo de acumulação do capital sempre foram o motor propulsor das transformações espaciais. Entretanto, contemporaneamente, percebe-se que o que vem ocorrendo no solo urbano não é apenas conseqüência de modificações na produção ou na distribuição, mas sim uma peça fundamental do processo.

$\mathrm{Na}$ maioria dos países, essa associação entre a configuração espacial e a acumulação capitalista vem se consolidando como metodologia de gestão pública neoliberal, sustentada por estratégias de planejamento urbano capazes de descobrir, inventar e explorar possibilidades econômicas das cidades, mesmo a altos custos sociais para a maioria, dentro do principio de que é preciso favorecer os investimentos privados para garantir trabalho e a renovação do espaço, pois conforme o lugar os lucros do capital podem ser maiores.

Nesses moldes, a cidade Santos adotou medidas de reurbanização para a Avenida Conselheiro Nébias cujas definições apontam para a valorização econômica da área sem garantias de permanência dos atuais moradores e usuários, o que levou a concluir que, tal como ocorreu durante as reformas higienistas no passado, a efetivação do plano resultará em gentrificação com a expulsão dessa gente simples do local.

Esse trabalho defendeu que, nesse processo, não só os moradores da avenida serão prejudicados como também o restante da população da cidade e do país, haja vista o valor histórico e simbólico do eixo formado pela Conselheiro Nébias, uma vez que seus quarteirões são vestígios do apogeu momento exportador, decisivo para desenvolvimento econômico de São Paulo, e de diferentes 
décadas da primeira metade do século $\mathrm{XX}$, por conseguinte, da modernização capitalista conduzindo ao foco da industrialização brasileira.

Assim, em Santos, a desvalorização do patrimônio edificado, que há décadas vem ocorrendo para responder aos interesses do mercado imobiliário, está sendo acelerada pelas determinações do planejamento urbano, uma vez que as políticas de favorecimento das estratégias de lucro elegeram apenas o centro, ou o bairro central, como único espaço detentor de memória e história da cidade.

Pudemos verificar que a teoria aponta que falta de resquícios de memória neutraliza a identidade, tornando o presente incompreensível e a projeção de futuro impossibilitada, sem o referencial do passado. Desse modo, foi possível concluir que a manutenção de determinadas memórias em detrimento de outras privilegia não só interesses econômicos específicos como também se torna estratégia de controle social.

No patrimônio, o reconhecimento de uma única área como detentora de memória pública pode funcionar como um instrumento que acentua e evidencia relações de exclusão e dominação cultural, já que quando se protege um bem também está sendo protegida a cultura e as práticas sociais por ele representadas. Dentro do atual planejamento urbano, esse processo de escolha omite as estratégias de marketing para atrair investidores, alegando a preservação da história pública.

Pudemos perceber no estudo da Avenida Conselheiro Nébias que, se por um lado o poder público direciona a configuração espacial amparado por um discurso imbuído da idéia de desenvolvimento de Santos, por outro lado isso significa não só a expulsão como perda material, mas a própria transgressão dos 
direitos humanos, no âmbito cultural. O direito à cultura, uma vez reconhecido como direito universal a ser garantido pelo Estado, deve ser considerado nas atuações dos órgãos de preservação e de planejamento urbano, com a finalidade de combater a amnésia social, fruto da sociedade de consumo, que impede o envelhecimento das coisas através da obsolescência e das substituições aceleradas.

Preservar as identidades urbanas da cidade a partir do seu valor cultural é uma forma de resistência as forças econômicas do mercado. Essa reapropriação da cidade permite que a democracia deixe seu caráter "ficcional pósmoderno" e devolva a cidade aos cidadãos.

A partir dessas considerações, a dissertação procurou contribuir para a atuação do arquiteto urbanista propondo medidas que incorporam identidades urbanas às intervenções na cidade, a fim de preservá-las. Propõe-se que essa preservação seja feita a partir de modificações na legislação urbanística, sem a necessidade do tombamento integral da avenida, com o objetivo de assegurar o direito cultural dos seus habitantes e de toda uma ampla coletividade que atinge a cidade e a ultrapassa, para a qual Santos se mostra local de construção de um passado comum, visando à manutenção da memória pública e da identidade urbana. 


\section{V.2. Proposta: diretrizes para uma nova legislação.}

As modificações propostas para a regulamentação urbana do segmento da Avenida Conselheiro Nébias anteriormente apresentado visam à preservação de um eixo tão importante para a história de Santos, nas suas dimensões materiais e sociais. Entretanto, apesar do caráter documental de tais grupos tipológicos, eles não configuram excepcionalidades isoladamente, nem formam conjuntos arquitetônicos, de modo que o tombamento de toda a extensão desse segmento não seria justificável ou prudente. Além disso, os bens já reconhecidos e protegidos legalmente pelo órgão competente têm sofrido obstrução de sua visibilidade devido à descaracterização do seu entorno, processo que tende a piorar cada vez mais com as resoluções do Plano Diretor Municipal, já expostas.

Sendo assim, as medidas descritas a seguir incorporam à regulamentação edilícia e de uso do solo preceitos necessários para a preservação da visibilidade e da ambiência dos bens tombados, além da manutenção do perfil da área através da preservação da volumetria de alguns grupos tipológicos e da manutenção do gabarito baixo. Dessa forma, entende-se que a valorização montaria dos terrenos será muito limitada e que o êxito de programas de preservação do patrimônio histórico, arquitetônico e cultural só ocorrerá à custa do equacionamento de suas ações às do planejamento urbano. Além disso, agrega-se ao planejamento uma visão social, norteada pelos e para os atores sociais e suas práticas urbanas, inibindo processos censuráveis como o de gentrificação.

Esse diálogo entre recomendações preservacionistas e as ações do planejamento urbano teve início, ao menos no campo teórico-conceitual, no final do século XIX, sendo consolidado no século seguinte. Em 1964, por exemplo, a Carta 
de Veneza declarava internacionalmente que a "conservação de um monumento exige a preservação da vizinhança à sua escala" e que deveria ser "proscrita toda construção nova, toda demolição ou alteração que possa modificar as relações de volumetria e cor ${ }^{3,56}$.

Anteriormente à carta, no entanto, Gustavo Giovannoni já havia afirmado que a cidade per si constituía um monumento, embora fosse, ao mesmo tempo, um tecido vivo. É a partir dessa dualidade que o autor estruturou sua doutrina de conservação e restauração do patrimônio urbano, cujo primeiro grande princípio é a inserção de áreas históricas num plano diretor (piano regolatore) local, regional e territorial, antevendo a integração dessas áreas a ordenação da vida presente. Para Giovannoni, o monumento é sempre parte de uma "arquitetura maior", de um conjunto urbano, sendo imprudente separar ou isolar um edifício do contexto no qual se insere. Destacá-lo do seu entorno, para o autor, é o mesmo que mutilá-lo e é justamente essa ambiência ${ }^{57}$ que deve reger as intervenções (CHOAY, 2001).

Posteriormente, o Conselho da Europa - através do documento chamado Declaração de Amsterdã ${ }^{58}$ em virtude do Congresso do Patrimônio Europeu realizado naquela cidade em outubro de 1975, propôs a "conservação integrada" através de um diálogo entre conservadores e planejadores, a fim de que o ordenamento da cidade acolha as exigências da conservação do patrimônio arquitetônico. Além disso, a preocupação central do documento é a manutenção dos

\footnotetext{
${ }^{56} \mathrm{O}$ documento na íntegra pode ser obtido no site do IPHAN: $\underline{\text { www.iphan.gov.br }}$

57 Choay (2001) faz uma longa nota a respeito da tradução do termo que, segundo ela, "designa as conseqüencias benéficas sobre a percepção da articulação dos elementos na malha urbana" ou "espírito (histórico) dos lugares, materializado em configurações espaciais” (CHOAY, 2001, p. 200-201).

${ }^{58} \mathrm{O}$ documento na íntegra pode ser obtido no site do IPHAN: www.iphan.gov.br
} 
habitantes nessas áreas após serem recuperadas, sendo o fator social a condicionante principal de toda política de conservação integrada. Ao Poder Público é designada a responsabilidade de promover ações que garantam a permanência da população residente em áreas históricas, principalmente naquelas em declínio econômico, de modo a impedir a ocorrência de fenômenos como o de gentrificação.

"Para evitar que as leis do mercado sejam aplicadas com todo rigor nos bairros restaurados o que teria por conseqüência a evasão dos habitantes, incapazes de pagar aluguéis majorados, é necessária uma intervenção dos poderes públicos no sentido de moderar os mecanismos econômicos, como sempre é feito quando se trata de estabelecimentos sociais. As intervenções financeiras podem se equilibrar entre os incentivos à restauração, concedidos aos proprietários através de fixação de tetos para os aluguéis e da alocação de indenizações de moradia aos locatários, para diminuir ou mesmo completar a diferença existente entre os antigos e os novos aluguéis." (Declaração de Amsterdã, 1975, p. 06)

No Brasil, algumas experiências foram realizadas no sentido de utilizar ações de gestão urbana como instrumento para a preservação de áreas históricas sem a necessidade do recurso do tombamento - que deve ser reservado a bens ímpares ou ameaçados de destruição. A título de exemplificação podem ser citados dois projetos no Rio de Janeiro: o Projeto Petrópolis e o Projeto Morro da Conceição ${ }^{59}$. Ambos se caracterizam por buscar a preservação de áreas culturais e históricas que se encontravam ameaçadas principalmente por atuações imprudentes do planejamento urbano. Além disso, é importante destacar que nos dois casos existiam bens tombados ameaçados pelos seus respectivos planos diretores. $O$ sucesso dos dois projetos foi justamente o entendimento de que a preservação dos bens tombados envolvia, impreterivelmente, a conservação tanto de seus entornos quanto das suas características sociais e econômicas.

\footnotetext{
${ }^{59}$ O Projeto Petrópolis e o Projeto Morro da Conceição foram detalhadamente apresentados na revista do IPHAN n. 19, 1984, nas páginas 33-39 e 97-111, respectivamente.
} 
Voltando ao caso santista, a metodologia utilizada tanto para o levantamento da avenida quanto para o modo de organização e análise dos dados se assemelha muito àquela utilizada pela coordenadora do Projeto Morro da Conceição, Jurema Kopke Eis Arnaut ${ }^{60}$. Naquele projeto, também foi feito um levantamento cadastral, através de fichas simples, para identificação do entorno dos monumentos, seguida de uma identificação do potencial histórico e estético da área e das implicações advindas das indicações municipais. Logo após, foi feito um mapeamento dos dados colhidos, considerando as expectativas municipais para a organização urbana da cidade. Finalmente, tem-se a elaboração de uma portaria de controle de gabaritos e forma de ocupação, com o objetivo de resguardar o entorno dos bens tombados.

No caso santista, a primeira diretriz sugerida é que sejam abolidas desse segmento da avenida as especificações do zoneamento "Corredor de Desenvolvimento e Renovação Urbana" - CDRU. É certo que as operações que ele envolve são garantidas pelo Estatuto da Cidade, no entanto, suas propostas de renovação e verticalização para esse trecho ímpar implicariam em mudanças significativas na sua estrutura social, às quais a materialidade está intrinsecamente vinculada.

O zoneamento, de modo geral, é um instrumento que até certo ponto homogeneíza as construções através da segregação social. Nesse tipo de organização espacial não são consideradas a memória e a identidade dos moradores, as tipologias existentes, o convívio e a socialização entre classes. $\mathrm{Na}$

\footnotetext{
${ }^{60}$ Embora haja semelhanças, destaco que a metodologia utilizada para a apreensão do segmento abordado nesta dissertação foi desenvolvida antes do conhecimento do artigo que descreve o Projeto Morro da Conceição, acessado no começo de 2007 no site do IPHAN. Longe de almejar méritos pelo acaso, alegro-me pela aproximação de idéias, considerando a experiência profissional da autora do artigo. Creio que, talvez, a proximidade da problemática dos casos tenha sido a razão da afinidade metodológica.
} 
maioria das vezes, ajuda a acentuar visões racistas e preconceituosas sobre diferenças sociais e está permeado de barganhas políticas negociadas pela elite na tentativa de se privar das mazelas sociais (LANNA, 1996; ROLNIK, 2003).

A proposta incorpora às normativas edilícias e de uso do solo a volumetria dos grupos tipológicos existentes e o entorno dos bens tombados. Portanto, o zoneamento é definido por quadras e não por regiões, de modo a estabelecer coeficientes de aproveitamento e índices de ocupação em função das características dos grupos tipológicos mais recorrentes, ou seja, naquelas quadras onde há concentração de determinado grupo, o potencial construtivo é estabelecido de acordo com a volumetria do grupo em questão. Já naquelas onde há poucos exemplares de qualquer um dos grupos, os coeficientes e índices seriam relativos a quatro pavimentos. Esse gabarito é estipulado em função do perfil morfológico da avenida, que varia da altura de dois pavimentos com porão habitável até três pavimentos sobre pilotis - o que resulta em uma altura média proporcional a quatro pavimentos.

"Da perspectiva do patrimônio como documento histórico, os sítios urbanos deveriam ser valorados em função de sua forma, como o resultado daquilo que culturalmente se produziu pela constante reapropriação do espaço, pelos vários significados que the foram atribuídos, pelos vários usos e funções sociais que possuiu, assim como o resultado de uma construção social que contemplou diferentes interesses e forças em disputa." (MOTTA, 2000, p. 284)

Dos treze grupos encontrados, quatro não apresentam características a serem preservadas seja pela condição em que se encontram lotes não edificados, edifícios em construção, ou edifícios sem diálogo com o entorno. Do total, apenas esses quatro não foram considerados para a formulação dessas diretrizes, são eles: grupo 10, 11, 12 e 13 (ver Anexo A, páginas 217 a 230). 
Do restante, consideraram-se a volumetria e, principalmente, o gabarito de altura como parâmetros para permitir o aproveitamento e a ocupação do lote no caso de novas construções ou reformas.

Seguindo a numeração estabelecida no Mapa Geral (ver Anexo B, página 232), as diretrizes são ${ }^{61}$ :

1. Nas quadras $3,7,8,9,14,15,17,19$, ficam definidos para os lotes voltados à Avenida Conselheiro Nébias e compreendidos entre as transversais Rua Bittencour até a Avenida Vicente de Carvalho:

- Para os efeitos de parcelamento, lote mínimo de $250 \mathrm{~m} 2$ (duzentos e cinqüenta metros quadrados) com testada mínima de 9,00 (nove metros), coeficiente de aproveitamento máximo c.a. $=0,92$ e taxa de ocupação máxima t.o. $=$ $46,27 \%$, limitando as novas construções a até 2 (dois) pavimentos.

- Para os lotes já parcelados, reformas e novas construções limitadas a atingirem até 2 pavimentos. Nos lotes onde os edifícios já apresentem número de pavimentos superiores a 2 , admite-se que não poderão atingir altura superior àquela consolidada até o presente momento.

- As novas construções deverão obedecer aos já estabelecidos recuos - frontal mínimo 7,00m (sete metros); divisas laterais e

\footnotetext{
${ }^{61} \mathrm{O}$ mapa demonstrativo das diretrizes de preservação está no Anexo B, página 238.
} 
fundos, mínimo 1,50m (um metro e cinqüenta centímetros) cada.

- A definição anterior que admite para o pavimento térreo pé direito máximo de $7,50 \mathrm{~m}$ (sete metros e cinqüenta centímetros), incluindo o mezanino, não se aplica a essas quadras.

2. Nas quadras $1,4,6,16,18$, ficam definidas para os lotes voltados à Avenida Conselheiro Nébias, da Rua Bittencour até a Avenida Vicente de Carvalho, as seguintes diretrizes:

- Para os efeitos de parcelamento, lote mínimo de $250 \mathrm{~m} 2$ (duzentos e cinqüenta metros quadrados) e testada mínima de 9,00 (nove metros), coeficiente de aproveitamento máximo $=1,85$ e taxa de ocupação máxima $=46,27 \%$, limitando as novas construções em até 4 (quatro) pavimentos, dos quais 3 (três) sobre pilotis.

- Para os lotes já parcelados, reformas e novas construções poderão atingir a altura de até 4 pavimentos, dos quais 3 sobre pilotis. Nos lotes onde os edifícios já apresentem altura superior a 4 pavimentos, admite-se que não poderão atingir altura maior que aquela já consolidada no presente momento.

- As novas construções deverão obedecer aos recuos de: frontal mínimo 7,00m (sete metros); divisas laterais e fundos mínimo de 1,50m (um metro e cinqüenta centímetros) cada. 
- A definição anterior que admite para o pavimento térreo pé direito máximo de $7,50 \mathrm{~m}$ (sete metros e cinqüenta centímetros), incluindo o mezanino, não se aplica a essas quadras.

3. Nas quadras $22,23,24,25,26$ e 27 ficam definidos para os lotes voltados à Avenida Conselheiro Nébias, da Rua Bittencour até a Avenida Campos Sales:

- A quadra 23 apresenta um bem protegido por nível 2 (lote número 1 da quadra 23) - proteção estabelecida por especificação do tombamento da Estação Elevatória de Saturnino de Brito, localizada na quadra 22 lote 1, na esquina da avenida com a Campos Sales.

- Na quadra 25 existem duas edificações em estudo de tombamento (lotes 8 e 9).

- Na quadra 27 há uma edificação que apresenta características importantes a serem preservadas talvez pelo tombamento - nível 1 de proteção.

- Além disso, esse trecho apresenta gabarito em altura homogêneo, com $66 \%$ dos lotes edificados com até 2 pavimentos.

- Devido a essas características e a presença de 5 bens interessantes a serem preservados, propõe-se as mesmas definições do item 1 dessas diretrizes. 
- Acrescenta-se apenas que os recuos frontais e laterais não se aplicam devido ao alinhamento seguido pelas edificações já existentes e a presença de conjuntos geminados típicos da região.

4. Nas quadras restantes ficam definidos para os lotes voltados à Avenida Conselheiro Nébias, da Rua Bittencour até a Avenida Vicente de Carvalho:

- As mesmas resoluções do item 2, com a ressalva da obrigatoriedade de serem construídas sobre pilotis. Dessa forma, serão construções de até 4 pavimentos devendo obedecer aos recuos estipulados e índices mínimos quando de um novo parcelamento dos lotes.

Através da substituição do zoneamento tradicional pela normativa de quadras, acredito que seja possível preservar parcialmente o perfil da área sem sufocar a capacidade criadora dos arquitetos e construtores de Santos. Entretanto, como alertou Maurício Nogueira Baptista (1984) ao analisar o Projeto Petrópolis, a imposição de restrições ao aproveitamento do solo urbano interrompe uma prática muito lucrativa consolidada entre os construtores que transformam radicalmente paisagens urbanas, construindo prédios multifamiliares em lotes que abrigavam anteriormente uma única família, como ocorre na Avenida Conselheiro Nébias, por exemplo.

Sendo assim, a estipulação de normas legais e o desempenho ativo do Poder Público assumem importância fundamental diante dos interesses 
envolvidos, a fim de mediar e discernir dentre as posições divergentes aquela que melhor se identifica com o bem comum. 


\section{BIBLIOGRAFIA}

ABREU, Regina; CHAGAS, Mário. Memória e patrimônio: ensaios contemporâneos. Rio de Janeiro: DP\&A, 2003.

ABREU, Regina. A emergência do patrimônio genético e a nova configuração do campo do patrimônio. In: ABREU, Regina; CHAGAS, Mário. Memória e patrimônio: ensaios contemporâneos. Rio de Janeiro: DP\&A, 2003, p. 30 - 45.

ANDRADE, Carlos Roberto Monteiro. A peste e o plano: o urbanismo sanitarista do engenheiro Saturnino de Brito. 1992. Dissertação (mestrado) - FAU USP, São Paulo.

O plano de Saturnino de Brito para Santos e a construção da cidade moderna no Brasil. In: Espaço e Debates, São Paulo: NERU, n. 34, p. 55-63, 1991.

ANDRADE, Wilma Therezinha Fernandes de. O discurso do progresso: a evolução urbana de Santos, 1870-1930. 1989. Tese (doutorado) - Faculdade de Filosofia, Letras e Ciências Humanas da Universidade de São Paulo, São Paulo.

. Santos: urbanismo na época do café: 1889-1930. In: Pereira, Maria Aparecida Franco (org). Santos: Café e História. Santos: ed. Leopoldianum, p. 89106, 1995.

ARANTES, Antonio Augusto. Patrimônio cultural e nação. In: ARAÚJO, Ângela Maria (org). Trabalho, cultura e cidadania: um balanço da história social brasileira. São Paulo: Ed. Setta, 1997.

ARANTES, Otília. Uma estratégia fatal: a cultura nas novas gestões urbanas. In: ARANTES, Otília; MARICATO, Ermínia; VAINER, Carlos. A cidade do pensamento único. Petrópolis: Ed. Vozes, 2000.

ARENDT, Hannah. Entre o passado e o futuro. São Paulo: ed. Perspectiva, 1992.

ARGAN, G. Carlo. História da arte como história da cidade. São Paulo: ed. Martins Fontes, 1998. . Projeto e destino. São Paulo: ed. Ática, 2001.

ARNAUT, Jurema. Uma proposta de preservação sem tombamento: Morro da Conceição. Revista do Patrimônio Histórico e Artístico Nacional, n. 19, p. 97-111, 1984.

BARROS, Myriam Moraes Lins de. Memória e família. Revista Estudos Históricos, n. 3, p. 29-42, 1989.

BAPTISTA, Maurício Nogueira. O planejamento como instrumento de preservação. Revista do Patrimônio Histórico e Artístico Nacional, n. 19, p. 33-39, 1984.

BAUMAN, Zygmunt. Identidade. Rio de Janeiro: ed. Jorge Zahar, 2005. 
BERNARDINI, Sidney. Os planos da cidade: as políticas de intervenção urbana em Santos - de Estevan Fuertes a Saturnino de Brito (1892-1910). São Carlos: ed. RIMA / FAPESP, 2006.

BLUME, Luis Henrique dos Santos. A moradia da população pobre e a reforma urbana em Santos no final do século XIX. 1998. Dissertação (mestrado) - Faculdade de História da PUC-SP, São Paulo.

BOSI, Ecléa. Memória e sociedade: lembrança de velhos. São Paulo: ed. Companhia das Letras, 1994.

BRANDI, Cesare. Teoria da restauração. São Paulo: Ed. Ateliê, 2004.

BRITO, Celso. Poesias. Disponível em:

http://www.revista.agulha.nom.br/celsobrito4.html\#encontro. Acesso em: outubro de 2006.

BULHÕES, Maria Amélia. Identidade, uma memória a ser enfrentada. Revista Arte e Cultura da América Latina, vol. VI, n. 01, p. 73-86, 1999.

CALDATTO, Gino. Santos e seus Arrabaldes - Álbum de Militão Augusto de Azevedo. São Paulo: ed. Magma Editora Cultural, 2004.

CALVINO, Ítalo. As cidades invisíveis. São Paulo: ed. Companhia das Letras, 1990.

CAMPOS, Jorge L. Sobre Riegl, Panofsky e Cassirer: a intencionalidade histórica da representação espacial. Revista eletrônica: Agulha - Revista de Cultura, Fortaleza e São Paulo, n.26, jul. 2002. Disponível em:

<http://www.revista.agulha.nom.br/ag26campos.htm> Acesso em: 10 jul. 2006.

CANCLINI, N. García. Culturas híbridas. São Paulo: Edusp, 2003.

. O patrimônio cultural e a construção imaginária do nacional. Revista do Patrimônio Histórico e Artístico Nacional, n. 23, p. 95-115, 1994.

CANEVACCI, Massimo. A cidade polifônica: ensaio sobre a antropologia da comunicação urbana. São Paulo: Studio Nobel, 1993.

CARTAS PATRIMONIAIS. As cartas patrimoniais e os documentos internacionais citados no texto estão disponíveis no site http://portal.iphan.gov.br/ sob o link "cartas patrimoniais". Acesso: agosto de 2007.

CARRIÇO, José Marques. O plano de Saturnino de Brito para Santos: urbanismo e planejamento urbano entre o discurso e a prática. Disponível em: http://www.canaisdesantos.com.br/artigos.asp?idnot $=160$ acesso em: janeiro de 2007.

CARVALHO, Sonia Nahas. Plano Diretor em Santos: política negociada. Disponível em: http://www.scielo.br/scielo.php?script=sci arttext\&pid=S0102$\underline{88392001000100014}$ acesso em: 15 janeiro de 2007. 
CHAGAS, Mário. Memória política e política de memória. In: ABREU, Regina; CHAGAS, Mário. Memória e patrimônio: ensaios contemporâneos. Rio de Janeiro: DP\&A, 2003, p. 141-171.

CHAUÍ, Marilena. Política cultural, cultura política e patrimônio histórico. In: Secretaria Municipal de Cultura de São Paulo. O direito à memória: patrimônio histórico e cidadania. São Paulo: DPH, 1992.

CHOAY, Françoise. A alegoria do patrimônio. São Paulo: Ed. UNESP, 2001.

CORBIN, Alain. O território do Vazio: a praia e o imaginário ocidental. São Paulo: ed. Companhia das Letras, 1989.

CUNHA, Maria Clementina Pereira (org). O direito a memória: patrimônio histórico e cidadania. São Paulo: Secretaria Municipal de Cultura de São Paulo/DPH, 1992.

FONSECA, Maria Cecília Londres. O Patrimônio em Processo: trajetória da política federal de preservação no Brasil. Rio de Janeiro: Ed. UFRJ; MinC - Iphan, 2005. 2ª . ed.

FOUCAULT, Michel. A arqueologia do saber. Rio de Janeiro: ed. Forense Universitária, 2000. . Microfísica do poder. Rio de Janeiro: ed. Edições Graal, 1998.

FRUTUOSO, Maria Suzel Gil. O café e a imigração em Santos. In: PEREIRA, Maria Aparecida Franco (org). Santos: Café e História. Santos: ed. Leopoldianum, 1995.

FURTADO, Celso. Formação econômica do Brasil. São Paulo: ed.Companhia Editora Nacional, 2001.

GAMBETA, Wilson Roberto. Desacumular a pobreza: Santos, limiar do século. In: Espaço e Debates, São Paulo: NERU, n. 11, p. 17-27, 1984.

GITAHY, Maria Lucia Caira. Ventos do Mar: trabalhadores do porto, movimento operário e cultura urbana em Santos, 1889-1914. São Paulo: ed. UNESP, 1992.

GONÇALVES, Alcindo. Lutas e Sonhos: Cultura política e hegemonia progressista em Santos, 1945 - 1962. São Paulo: UNESP, 1995.

GONÇALVES, José Reginaldo Santos. A retórica da perda. Rio de Janeiro: ed. UFRJ / Iphan, 2002.

GUARINELLO, Norberto Luiz. Memória coletiva e história científica. Revista Brasileira de História, n. 28, p. 180-193, 1995.

HALBWACHS, Maurice. A memória coletiva. São Paulo: ed. Centauro, 2006.

HARVEY, David. A brief history of neoliberalism. Oxford: ed. Oxford University Press, 2005. 
HOBSBAWM, Eric; RANGER, Terence. A invenção das tradições. Rio de Janeiro: ed. Paz e Terra, 2006.

HOBSBAWM, Eric. A era do capital: 1848-1875. Rio de Janeiro: Ed. Paz e Terra, 1996.

HUYSSEN, Andreas. Seduzidos pela memória. Rio de Janeiro: ed. Aeroplano, 2000.

JARDIM, José Maria. A invenção da memória nos arquivos públicos. Revista Ciência da Informação, vol. 25, n. 02, 1995.

KARA-JOSÉ, Beatriz. Políticas culturais e negócios urbanos: a instrumentalização da cultura na revitalização do centro de São Paulo (1975-2000). São Paulo: Annablume; FAPESP, 2007.

KÜHL, Beatriz M. História e ética na conservação e na restauração de monumentos históricos. Revista eletrônica CPC, São Paulo, v. 01, nov. 2005 - abr. 2006.

Disponível em:

http://www.usp.br/cpc/v1/php/wf07 revista interna.php?id revista=2\&id conteudo=6 \&tipo=5. Acesso em: 09 ago. 2006.

KÜHL, Beatriz M. Restauração hoje: método, projeto e criatividade. In: Revista Desígnio, São Paulo: ed. Annablume, n. 06, 2007 (no prelo).

LANNA, Ana Lúcia Duarte. Uma cidade na transição. Santos: 1870 - 1913. São Paulo/Santos: ed. Hucitec e Prefeitura Municipal de Santos, 1996.

LE GOFF, Jacques. História e memória. Campinas: ed. Unicamp / Centro de Memória, 2003.

LEPETIT, Bernard. Por uma nova história urbana. São Paulo: ed. EDUSP, 2001.

LÉVI-STRAUSS, Claude. Tristes trópicos. São Paulo: ed. Anhembi,1957.

LOPES, Denise Remião. Descobertas históricas sobre a memória humana. Artigo para avaliação final no curso de História das Neurociências pelo Instituto Edumed Educação em Medicina e Saúde / UNICAMP. Disponível em:

http://www.edumed.org.br/cursos/neurociencia/01/Monografias/historia-memoria.doc. Acesso em: abril de 2007.

MEDEIROS, Wilton. A decifração da cidade. Artigo para Instituto Goiano de PréHistória e Antropologia (IGPA) - Universidade Católica de Goiás. Disponível em: http://www.ucg.br/projetogoiania/Artigowila.html acesso em: abril 2007.

MENDES, Carlos Pimentel. Trilhos: do chic ao chiqueiro. Disponível em: http://www.novomilenio.inf.br/santos/trilho19.htm acesso em: setembro de 2006

MENESES, Ulpiano T. Bezerra. Memória e cultura material: documentos pessoais no espaço público. Revista Estudos Históricos, n. 21, 1998. 
A história, cativa da memória? Para um mapeamento da memória no campo das Ciências Sociais. Revista do Instituto de Estudos Brasileiros, n. 34, p. 0923, 1992.

O patrimônio cultural entre o público e o privado. In: Secretaria Municipal de Cultura de São Paulo. O direito à memória: patrimônio histórico e cidadania. São Paulo: DPH, 1992.

. Patrimônio ambiental urbano: do lugar comum ao lugar de todos. Revista C J Arquitetura, Rio de Janeiro, n. 19, p. 45-46, 1978.

MILLIET, Sergio. Roteiro do café e outros ensaios. São Paulo: ed. Hucitec, 1982.

MONBEIG, Pierre. Pioneiros e fazendeiros de São Paulo. São Paulo: ed. Hucitec, 1984.

MONDIN, Leda. Vila Nova e a ironia dos contrastes. Disponível em:

http://www.novomilenio.inf.br/santos/h0100b13.htm acesso em dezembro de 2006.

MOREIRA, Clarissa Costa. A cidade contemporânea: entre a tabula rasa e a preservação. São Paulo: ed. UNESP, 2004.

MOTTA, Lia. A apropriação do patrimônio urbano: do estético-estilístico nacional ao consumo visual global. In: ARANTES, Antonio Augusto (org). O espaço da diferença. Campinas: ed. Papirus, 2000.

NEGRÃO, João José. Para conhecer o neoliberalismo. São Paulo: ed. Publisher Brasil, 1998.

NUNES, Luiz Antonio de Paula. Saber técnico e legislação: a formação do urbanismo em Santos - 1894 a 1951. 2001. Dissertação (mestrado) - FAU USP, São Paulo.

PEREIRA, Maria Aparecida Franco (org). Santos: Café e História. Santos: ed. Leopoldianum, 1995.

Comércio cafeeiro na praça de Santos: o comissário de café (18701920). In: PEREIRA, Maria Aparecida Franco (org). Santos: Café e História. Santos: ed. Leopoldianum, 1995.

POLLAK, Michael. Memória, esquecimento, silêncio. Revista Estudos Históricos, $\mathrm{n}$. 3, p. 03-15, 1989.

p. 01-15, 1992.

Memória e identidade social. Revista Estudos Históricos, vol. 5, n. 10,

PRODESAN - Progresso e Desenvolvimento de Santos S.A.. Benedito Calixto: reprodução de seis telas do grande pintor. Santos: Ed. Prodesan Gráfica, 1978.

RIBEIRO, Renato Janine. Memórias de si ou... Revista Estudos Históricos, n. 21, 1998. 
RIEGL, Alöis. El culto moderno a los monumentos. Madrid: Ed. Visor, 1999. . Problemas de estilo. Barcelona: Ed. Gustavo Gili, 1980.

RODRIGUES, Olao. Almanaque de Santos. Santos: ed. Ariel Editora e Publicidade, 1971.

ROLNIK, Raquel. A cidade e a Lei: legislação, política urbana e territórios na cidade de São Paulo. São Paulo: Ed. Studio Nobel : FAPESP, 2003. 3ª. ed.

ROSSI, Aldo. A arquitetura da cidade. São Paulo: ed. Martins Fontes, 2001.

SANTOS, Myrian Sepúlveda. Memória Coletiva e Teoria Social. São Paulo: ed. Annablume, 2003.

SILVA, Sergio. Expansão cafeeira e origens da indústria no Brasil. São Paulo: ed. Alfa-Omega, 1985.

SILVA, Ursula Rosa da. A fundamentação estética da crítica de arte em Ângelo Guido: a crítica de arte sob o enfoque de uma história das idéias. 2002, 147 f. Tese (Doutorado em História do Brasil) - Instituto de Filosofia e Ciências Humanas, Pontifícia Universidade Católica/RS, Porto Alegre, 2002. Disponível em: http://www.dominiopublico.gov.br/pesquisa/DetalheObraForm.do?select action=\&co obra=18996. Acesso em: 14 ago. 2006.

SZMRECSANYI, Maria Irene de Queiroz Ferreira. Produção, apropriação e organização do espaço na economia cafeeira: contrastes entre o Vale do Paraíba e o Oeste Paulista (1800 -1930). In: Sinopses, São Paulo: FAU USP, n. 5, 1984.

Rio e São Paulo: raízes da substituição da metrópole nacional. In: Revista USP, São Paulo: USP, n. 17: Dossiê Liberalismo/ Neoliberalismo, marçomaio, 1993.

VAINER, Carlos. Pátria, empresa e mercadoria. In: ARANTES, Otília; MARICATO, Ermínia; VAINER, Carlos. A cidade do pensamento único. Petrópolis: Ed. Vozes, 2000.

VARGAS, Heliana Comin; CASTILHO, Ana Luisa Howard de. Intervenções em centros urbanos: objetivos, estratégias e resultados. Barueri: ed. Manole, 2006.

ZUKIN, Sharon. Paisagens urbanas pós modernas: mapeando cultura e poder. Revista do Patrimônio Histórico e Artístico Nacional, n² 24, p. 205-219, 1996.

\section{Sites consultados:}

Alegra Centro - http://www.alegracentro.com.br/

Condepasa - http://www.santos.sp.gov.br/cultura/condepasa/condepasa.html

Jornal Eletrônico Novo Milênio - http://www.novomilenio.inf.br/ 
Prefeitura Municipal de Santos/SEPLAN http://www.santos.sp.gov.br/frames.php?pag=/planejamento/planejamento.php

Viva Santos - http://www.vivasantos.com.br/ 
ANEXOS

Anexo A - Grupos Tipológicos

Anexo B - Mapas

Anexo C - Levantamento IBGE 
ANEXO A 